\title{
DROUGHT EFFECTS ON SOIL CARBON DIOXIDE EFFLUX IN TWO ECOSYSTEMS IN CENTRAL SULAWESI, INDONESIA
}

Dissertation

zur Erlangung des akademischen Grades Doctor of Philosophy (PhD)

der Fakultät für Forstwissenschaften und Waldökologie

der Georg-August-Universität Göttingen

vorgelegt von

Oliver O. van Straaten

geboren in Bukoba, Tansania

Göttingen, Februar 2010 
1. Gutachter: Prof. Dr. Edzo Veldkamp

2. Gutachter: Prof. Dr. Kerstin Wiegand

Tag der mündlichen Prüfung:

12.05 .2010

(Datum) 
"Humankind has not woven the web of life. We are but one thread within it. Whatever we do to the web, we do to ourselves. All things are bound together. All things connect.

- Chief Seattle, 1854 - 


\section{Table of Contents}

Table of Contents

List of Figures

iii

List of Tables

iv

Summary

Zusammenfassung

vii

$\begin{array}{lll}\text { CHAPTER } 1 & \text { INTRODUCTION } & 1\end{array}$

1 Climate change and the carbon cycle 2

2 Soil respiration 3

$3 \quad$ Drought effects on tropical ecosystems 4

$4 \quad$ Project objectives and justifications $\quad 6$

$5 \quad$ Experiment design and implementation $\quad 7$

CHAPTER 2 SPATIAL AND TEMPORAL EFFECTS OF DROUGHT ON SOIL CO $\mathrm{O}_{2}$ EFFLUX

IN A CACAO AGROFORESTRY SYSTEM IN SULAWESI, INDONESIA 11

1

$\begin{array}{ll}\text { Introduction } & 13\end{array}$

2

Materials and Methods $\quad 14$

$\begin{array}{lll}2.1 & \text { Site description } & 14\end{array}$

$\begin{array}{ll}2.2 & 15\end{array}$

$2.3 \quad$ Soil surface $\mathrm{CO}_{2}$ efflux measurements 16

$2.4 \quad$ Soil air $\mathrm{CO}_{2}$ concentrations and soil moisture depth profiles $\quad 17$

$\begin{array}{lll}2.5 & \mathrm{CO}_{2} \text { leaching losses } & 19\end{array}$

$\begin{array}{lll}2.6 & \text { Isotope analysis } & 20\end{array}$

$\begin{array}{lll}2.7 & \text { Data analysis } & 20\end{array}$

$3 \quad$ Results 21

3.1 Volumetric soil water content and soil temperature 21

$\begin{array}{lll}3.2 & \text { Soil surface } \mathrm{CO}_{2} \text { efflux } & 21\end{array}$

3.3 Controls regulating $\mathrm{CO}_{2}$ efflux 26

$\begin{array}{ll}3.4 & \text { Leaf litter respiration } \\ 3.5 & 27\end{array}$

$\begin{array}{lll}3.5 & \text { Soil profile } \mathrm{CO}_{2} \text { concentrations } & 28\end{array}$

$\begin{array}{lll}3.6 & \mathrm{CO}_{2} \text { leaching losses } & 30\end{array}$

$4 \quad$ Discussions $\quad 30$

4.1 $\mathrm{CO}_{2}$ fluxes in a cacao agroforestry system 30

4.2 Drought effects on soil $\mathrm{CO}_{2}$ efflux 31

$4.3 \quad$ Belowground $\mathrm{CO}_{2}$ dynamics 34

4.4 Rewetting phases 34

$5 \quad$ Conclusions 35 
CHAPTER 3 EFFECTS OF A SIMULATED DROUGHT ON SOIL $\mathrm{CO}_{2}$ PRODUCTION IN A SUB-MONTANE TROPICAL FOREST IN CENTRAL SULAWESI, INDONESIA36

1

2

2.1

2.2

2.3

2.4

2.5

2.6

2.7

2.8

3

3.1

3.2

3.3

3.4

3.5

3.6

3.7

3.8

3.9

4

4.1

4.2

4.3

4.4

4.5

4.6

5

CHAPTER 4 SYNTHESIS

1

2

3

Results

Discussions
Introduction

Materials and Methods

Site description

Experimental design

Measurements of soil surface $\mathrm{CO}_{2}$ efflux

Root biomass

Soil air $\mathrm{CO}_{2}$ concentrations and soil moisture depth profiles

$\mathrm{CO}_{2}$ production in soil profiles

Isotope analysis

Data analysis

Soil moisture

Air and soil temperature

Soil $\mathrm{CO}_{2}$ efflux and environmental controls

$\mathrm{CO}_{2}$ production from leaf litter

$\mathrm{CO}_{2}$ production from roots and belowground heterotrophic sources

Root biomass

Distance to tree stems

Soil $\mathrm{CO}_{2}$ concentrations

Vertical soil $\mathrm{CO}_{2}$ dynamics

Environmental controls regulating soil $\mathrm{CO}_{2}$ production

Spatial, vertical and temporal $\mathrm{CO}_{2}$ production

Ecosystem drought response

Ecosystem rewetting

Modelling of soil $\mathrm{CO}_{2}$ production

Drought response comparison

Conclusions

69

Drought effects on soil $\mathrm{CO}_{2}$ production

70

Regional drought effect prediction

72

Drought risk prediction in tropical forests

38

39

39

40

41

43

43

44

46

47

48

48

49

50

53

54

56

56

56

58

61

61

62

63

65

66

67

68

72
REFERENCES

76

83

ACKNOWLEDGEMENTS

84

DEClaRATION OF ORIGINALITY AND CERTIFICATE OF OWNERSHIP

85

Curriculum Vitae 


\section{List of Figures}

\section{CHAPTER 1}

Figure 1: A simplified version of the global carbon cycle 3

Figure 2: Soil $\mathrm{CO}_{2}$ efflux processes $\quad 6$

Figure 3: The location of the two drought simulation experiments 7

Figure 4: Drought simulation experiment plot layout in the cacao / Gliricidia

$\begin{array}{ll}\text { agroforestry system } & 8\end{array}$

Figure 5: Drought simulation experiment plot layout of the tropical forest site 9

Figure 6: Pictures of the throughfall displacement roofs 9

\section{CHAPTER 2}

Figure 1: Soil $\mathrm{CO}_{2}$ efflux, soil $\mathrm{CO}_{2}$ leaching, volumetric water content and daily precipitation

Figure 2: Drought responsiveness map $\quad 24$

Figure 3: Drought responsive versus non-responsive $\mathrm{CO}_{2}$ efflux comparison 24

Figure 4: Relationship between soil water potential $(\mathrm{pF})$ and soil $\mathrm{CO}_{2}$ efflux 26

Figure 5: $\mathrm{CO}_{2}$ efflux from leaf litter contribution study in the control plots 28

Figure 6: Isopleths of average soil $\mathrm{CO}_{2}$ concentrations 29

\section{CHAPTER 3}

Figure 1: Soil $\mathrm{CO}_{2}$ efflux, volumetric water content and daily precipitation.

Figure 2: Relationship between soil water potential $(\mathrm{pF})$ and soil $\mathrm{CO}_{2}$ efflux

Figure 3: $\mathrm{CO}_{2}$ efflux from leaf litter contribution study in the control plots

Figure 4: Heterotrophic and autotrophic respiration

Figure 5: Relationship between soil moisture and autotrophic belowground heterotrophic and litter respiration

Figure 6: Soil gas $\mathrm{CO}_{2}$ concentrations in the soil profile

Figure 7: Comparison between modeled $\mathrm{CO}_{2}$ production and surface $\mathrm{CO}_{2}$ efflux

Figure 8: Soil $\mathrm{CO}_{2}$ production in the soil profile

Figure 9: Vertical $\mathrm{CO}_{2}$ production profile comparisons

\section{CHAPTER 4}

Figure 1: Potential drought risk map for natural tropical forests 


\section{List of Tables}

\section{CHAPTER 2}

Table 1: Soil physical and chemical properties

Table 2: Experiment soil surface $\mathrm{CO}_{2}$ efflux and soil air $\mathrm{CO}_{2}$ concentrations

Table 3: Diurnal soil $\mathrm{CO}_{2}$ efflux, soil temperature and air temperature

\section{CHAPTER 3}

Table 1: Soil physical and chemical properties

Table 2: Experiment soil surface $\mathrm{CO}_{2}$ efflux, soil air $\mathrm{CO}_{2}$ concentrations and soil $\mathrm{CO}_{2}$ production 52

Table 3: Diurnal soil $\mathrm{CO}_{2}$ efflux, soil and air temperature during daytime hours.

\section{CHAPTER 4}

Table 1: Drought response and biophysical site comparison of three throughfall displacement experiments in tropical forests 


\section{Summary}

Drought response on soil $\mathrm{CO}_{2}$ efflux and production dynamics were examined in two tropical ecosystems in central Sulawesi, Indonesia. Large-scale throughfall displacement roofs were built in a cacao (Theobroma cacao) / Gliricidia sepium agroforestry plantation (560 m.a.s.1.) and in an undisturbed sub-montane tropical rainforest (1,050 m.a.s.1.) to simulate drought conditions. At each site, ecosystem drought responses from three roof plots were compared to three undisturbed control plots. Soil $\mathrm{CO}_{2}$ production was measured spatially at the soil surface and vertically within the soil profile to $2.5 \mathrm{~m}$ depth every two weeks.

1. The simulated drought in the cacao / Gliricidia agroforestry ecosystem consisted of a one month baseline evaluation phase, a 13 months simulated drought and a five months rewetting phase. During the drought phase of the experiment soil $\mathrm{CO}_{2}$ efflux decreased by $13 \%$ in comparison to the control. The mild drought response is attributed to two reasons. First, soil $\mathrm{CO}_{2}$ efflux peaked at intermediate soil moisture contents, but was low when soil conditions became dry (in the induced drought plots) and when the soil became very wet (in the control plots). This means that respiration differences between control and roof plots may have been masked when soil moisture conditions were wet in the control and concurrently very dry in roof plots. Secondly, $\mathrm{CO}_{2}$ efflux drought response was localized. At some measurement chamber sites $(\mathrm{n}=11)$ drought effects were very pronounced: soil $\mathrm{CO}_{2}$ efflux decreased as soil moisture levels decreased. At other chamber sites $(n=7)$ however, there was no evident drought effect on soil $\mathrm{CO}_{2}$ emissions. Soil $\mathrm{CO}_{2}$ efflux was highest at the base of tree stems and decreased with distance radiating outwards. Overall, the experiment had a $\mathrm{CO}_{2}$ neutral effect: the decreases in emissions during the induced drought period were compensated for during the five month rewetting phase when $\mathrm{CO}_{2}$ efflux rebounded and surpassed the control.

2. The simulated drought in the undisturbed sub-montane tropical rainforest consisted of a two and a half months baseline evaluation phase, a 24.5 months simulated drought and a four months rewetting phase. In contrast to the cacao agroforest, the sub-montane tropical rainforest experienced a severe decrease in soil $\mathrm{CO}_{2}$ production. Here, soil $\mathrm{CO}_{2}$ efflux decreased by an average of $39 \%$ in comparison to the control during the induced drought period. Soil moisture, the main variable controlling $\mathrm{CO}_{2}$, exhibited a strong positive linear relationship with soil $\mathrm{CO}_{2}$ production $\left(\mathrm{R}^{2}=0.72\right)$. A two phase ecosystem drought response was observed. During the first phase, which lasted nine months, leaf litter respiration declined 
as did the $\mathrm{CO}_{2}$ production between 30 and $70 \mathrm{~cm}$ soil depth. During the second phase of the experiment (the next 16 months) drought conditions intensified further and belowground $\mathrm{CO}_{2}$ production from heterotrophic and autotrophic sources decreased at all soil depths. Leaf litter respiration remained negligible. Recuperation after the drought was slow in this ecosystem and did not rebound to control plot levels. In this ecosystem, the simulated drought resulted in a reduction in overall $\mathrm{CO}_{2}$ emission. 


\section{Zusammenfassung}

Zur Untersuchung des Einflusses von Trockenheitsperioden auf die unterirdische Kohlenstoffdynamik wurden Emissions- und Produktionsraten von $\mathrm{CO}_{2}$ in den Böden zweier tropischer Ökosysteme in Zentralsulawesi/Indonesien gemessen. Für diese Untersuchungen wurde eine künstliche Trockenheit mit Hilfe von Dächern aus durchsichtiger Folie erzeugt, die den Bestandesniederschlag von drei Versuchsflächen im Vergleich zu drei Kontrollflächen verringerten. Ein solches Trockenheitssimulationsexperiment wurde in einem Kakao (Theobroma cacao) / Gliricidia sepium Agroforst (560 m ü.NHN) durchgeführt, und ein weiters in einem sub-montanen tropischen Regenwald (1,050 m ü.NHN). Alle zwei Wochen wurde die Produktion von $\mathrm{CO}_{2}$ sowohl horizontal-räumlich als auch vertikal bis $\mathrm{zu}$ einer Tiefe von 2,5 m gemessen. Die $\mathrm{CO}_{2}$-Produktion der bedachten Flächen wurde dabei mit den Kontrollflächen verglichen.

Das Simulationsexperiment im Kakao / Gliricidia Agroforst bestand aus einer einmonatigen Vorphase (vor der künstlichen Austrocknung), gefolgt von einer 13 monatigen Trockenheitssimulation und einer fünfmonatigen Wiederbefeuchtungsphase. Während der Trockenphase war die $\mathrm{CO}_{2}$-Emission aus dem Boden im Vergleich zu den Kontrollflächen um $13 \%$ reduziert. Diese relativ schwache Reaktion kann auf zweierlei Weise erklärt werden. Die Emission von $\mathrm{CO}_{2}$ in den Dach- wie auch in den Kontrollflächen war bei mittlerer Bodenfeuchtigkeit am höchsten, und sehr niedrig wenn die Bodenfeuchte entweder sehr gering oder sehr hoch war. Daher konnten kaum Unterschiede in der Bodenrespirationsrate zwischen Kontrollflächen und Dachflächen festgestellt werden, wenn die Bodenfeuchtigkeit in den Kontrollflächen hoch war, während die Dachflächen gleichzeitig sehr trocken waren.

Weiterhin zeigten die von der simulierten Trockenheit beeinflussten $\mathrm{CO}_{2}$-Emissionen in den Dachflächen eine starke räumliche Variabilität. An einigen Messpunkten ( $n=11)$ war der Einfluss der simulierten Trockenheit sehr deutlich. Die $\mathrm{CO}_{2}$-Emissionen nahmen hier mit verminderter Bodenfeuchtigkeit ab. An anderen Messpunkten $(n=7)$ konnte dagegen kein Einfluss der Bodenfeuchte auf die $\mathrm{CO}_{2}$-Emissionen festgestellt werden. Die $\mathrm{CO}_{2}$-Emissionen des Bodens waren am höchsten am Fuß der Bäume und nahmen mit zunehmender Entfernung von diesen ab. Insgesamt glichen sich die $\mathrm{CO}_{2}$-Emissionen von Dach- und Kontrollflächen über die Zeitdauer des Experimentes aus: Die Emissionen auf den Dachflächen waren während der simulierten Trockenheit niedrig, nahmen aber während der fünfmonatigen Wiederbefeuchtungsphase zu, wobei sie sogar die Emissionen der Kontrollflächen übertrafen. 
In einem weiteren Trockenheitsexperiment wurde die unterirdische Kohlenstoffdynamik eines tropischen Regenwaldes untersucht. Das Simulationsexperiment begann mit einer zweieinhalbmonatigen Vorphase (vor der künstlichen Austrocknung), gefolgt von einer 24,5monatigen Trockenheitssimulation und einer viermonatigen Wiederbefeuchtungsphase. Im Gegensatz zu dem Experiment im Kakao / Gliricidia Agroforst war die $\mathrm{CO}_{2}$-Produktion im Regenwald bei Trockenheit stark vermindert. Die $\mathrm{CO}_{2}$-Emissionen in den Dachflächen nahmen im Vergleich zu den Kontrollflächen um durchschnittlich $39 \%$ ab. Die Bodenfeuchtigkeit, die Haupteinflussgröße der $\mathrm{CO}_{2}$-Produktion, war stark lineare positiv mit der $\mathrm{CO}_{2}$-Produktion korreliert $\left(\mathrm{R}^{2}=0.72\right)$. Die Reaktion auf die simulierte Trockenheit verlief in zwei Teilen: In den ersten neun Monaten nahm die Respirationsrate der Laubstreu ab, die autotrophe (Wurzeln) und die heterotrophe Respiration (Mikroorganismen) im Boden blieb indes unverändert. Die $\mathrm{CO}_{2}$-Produktion in den oberen Bodenschichten nahm dabei $\mathrm{zu}$, während sie in tieferen Schichten abnahm. Während der nächsten 16 Monate des Experiments verstärkte sich die Auswirkung der Trockenheit und die autotrophe und heterotrophe $\mathrm{CO}_{2}$ Produktion nahm in allen Bodentiefen ab. Die Respirationsrate der Laubstreu blieb dabei sehr gering. Während der Wiederbefeuchtungsphase stiegen die $\mathrm{CO}_{2}$-Emissionen in den Dachflächen an. Die Emissionswerte der Kontrollflächen wurden dabei allerdings nicht mehr erreicht. Im Ökosystem Regenwald führte eine Trockenheit daher zu insgesamt verminderten $\mathrm{CO}_{2}$-Emissionen. 


\section{CHAPTER 1}

\section{INTRODUCTION}
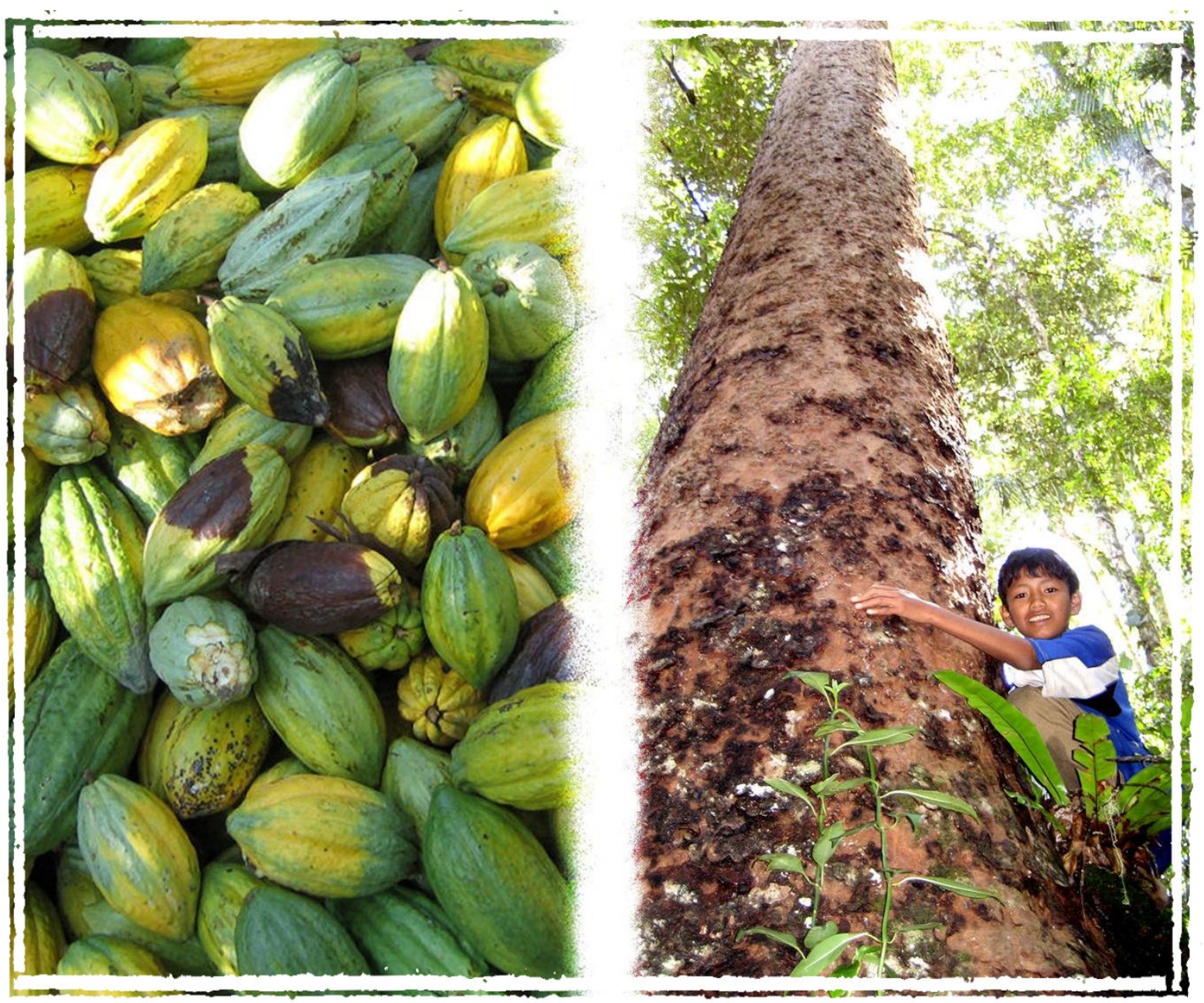


\section{Climate change and the carbon cycle}

Since the beginning of the industrial revolution, atmospheric carbon dioxide $\left(\mathrm{CO}_{2}\right)$ concentrations have been increasing exponentially as a result of anthropogenic $\mathrm{CO}_{2}$ emissions from fossil fuel burning, deforestation, land clearing and fire. Higher concentrations of $\mathrm{CO}_{2}$ and other greenhouse gasses in the atmosphere are causing an imbalance between incoming solar radiation and outgoing infrared radiation (Forster et al., 2007). The increased radiative forcing is causing global temperatures to rise. As a result, global and regional climate patterns are changing. The effects of global warming (rising temperatures, changing circulation patterns, rising sea levels, melting ice caps and higher frequencies of extreme weather events such as droughts, severe storms, and flooding) will have severe impacts on ecosystems worldwide and will affect the livelihoods of millions of people (IPCC, 2007).

Anthropogenic carbon dioxide emissions attributed to the global warming remain small however in comparison to natural sources coming from oceans and the terrestrial biosphere. The circulation of carbon through the atmosphere with the terrestrial biosphere, the ocean biosphere and the Earth's crust is known as the global carbon cycle (Fig. 1).

As illustrated in Figure 1, the global carbon pools contain 39,000 petagram carbon $\left(\mathrm{Pg}=10^{15} \mathrm{~g}\right)$ in oceanic pools, 6,000 Pg C bound in fossil fuels, 3,150 Pg stored as soil carbon, $750 \mathrm{Pg}$ in atmospheric carbon, and $650 \mathrm{Pg} \mathrm{C}$ stored in vegetation (Sabine et al., 2004). Soil carbon stocks alone contain four times more carbon than is stored in the atmospheric pool and nearly five times that in vegetation pool. The carbon pools are interconnected with each other and circulate carbon from one pool to the other. The exchanges of carbon between pools are called fluxes. In the terrestrial carbon cycle, $121 \mathrm{Pg} \mathrm{C}$

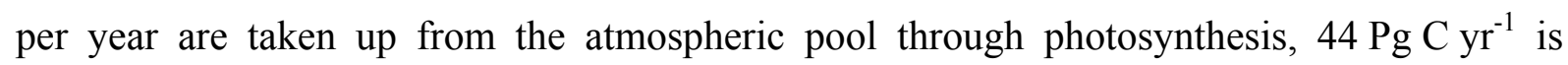
returned to the atmosphere through aboveground plant respiration and $75 \mathrm{Pg} \mathrm{C} \mathrm{yr}^{-1}$ by soil respiration (Luo and Zhou, 2006).

Prior to human manipulation of the carbon cycle, upward fluxes (emissions) into the atmosphere from natural sources were almost equally offset by transfers back into other carbon reservoirs (Schlesinger et al., 2000). The imbalance created by man-made carbon dioxide emissions illustrates that even slight changes in atmospheric $\mathrm{CO}_{2}$ concentrations will have severe consequences on global climate change. Global warming induced changes in terrestrial ecosystem functions and specifically in carbon allocations and stocks can therefore have potentially severe consequences on return fluxes to the atmosphere (Heimann and Reichstein, 2008). 


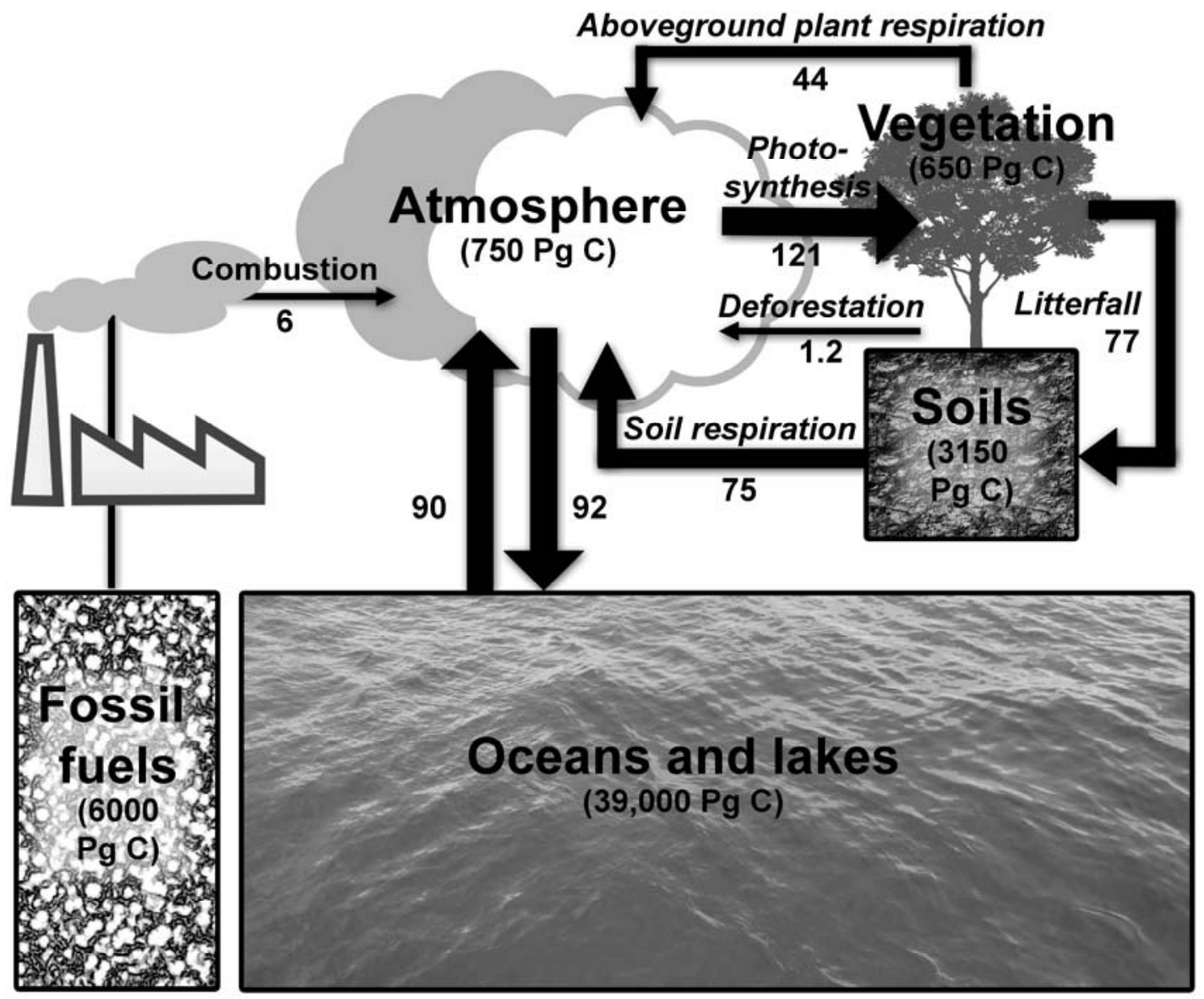

Figure 1: A simplified version of the global carbon cycle highlighting the carbon pools and fluxes associated with the atmosphere, the terrestrial biosphere and the oceans. The pools are expressed in Petagram $\left(\mathrm{Pg}=10^{15} \mathrm{~g}\right)$ and fluxes, indicated using arrows are in Pg $\mathrm{yr}^{-1}$ (Adapted from Brady and Weil (1999)).

Carbon dioxide concentrations and fluxes in the global carbon cycle have major influences on the dynamics of the global climate: on the hydrosphere, the atmosphere, the biosphere and on the pedosphere. While many studies have focused on the atmospheric and hydrospheric changes as well as on the impacts of climate change on the biosphere, very little emphasis has been given to soil carbon dynamics, especially in tropical environments.

\section{Soil respiration}

In the terrestrial environment, photosynthetic processes fix atmospheric carbon dioxide and convert $\mathrm{CO}_{2}$ to organic carbon compounds. Some of the carbon compounds produced are utilized by plants as an energy source, which in the process release $\mathrm{CO}_{2}$ back to the atmosphere. This is called plant respiration. Moreover, plants use carbon compounds to grow new leaves, roots, and wood. While leaves and roots may store carbon for a few months or years, wood can potentially retain carbon for decades or even centuries. Eventually however, 
when the organic matter dies it is decomposed by microorganisms, which in the process releases $\mathrm{CO}_{2}$ back into the atmosphere. This is referred to as heterotrophic respiration. Accumulated organic residues from dead plants and microbial biomass make up soil organic matter (SOM). The carbon stored in SOM can persist in the soil for hundreds to thousands of years before eventually being broken down. Respiration from roots is called belowground autotrophic respiration. Soil respiration, also referred to as $\mathrm{CO}_{2}$ efflux, is a combination of both heterotrophic and belowground autotrophic sources (Luo and Zhou, 2006).

Respiration is a biochemical process of living organisms (plants, micro-organisms, and animals), and the rate and quantity of $\mathrm{CO}_{2}$ produced through this process is determined by biological productivity of organisms and the environmental variables that affect them. Both soil temperature and soil moisture are regarded as the primarily controlling variables that influence soil respiration (Davidson et al., 2000, Raich and Schlesinger, 1992, Risk et al., 2002). Additionally however, soil $\mathrm{pH}$, soil texture, soil aeration and soil fertility are also important factors (Luo and Zhou, 2006).

\section{Drought effects on tropical ecosystems}

The complex chain of reactions caused by global temperature rises will also affect regional hydrological cycles (Bates et al., 2008). Anticipated increases in temperatures, combined with decreased precipitation, will enhance evapotranspiration and decrease soil moisture. Consequently, drought occurrence will become more common in many regions of the world. In the tropics, droughts have been linked to changes in sea surface temperatures, which through associated changes in atmospheric circulation patterns affects regional precipitation (Bates et al., 2008). The periodic El Niño Southern Oscillation (ENSO) phenomenon is one such anomaly, which historically has been shown to cause droughts. Quinn et al. (1978) for example, found that the ENSO phenomenon were associated with $93 \%$ of droughts experienced in Indonesia between 1830 and 1953. Recent research indicates that climatic changes will increase the frequency of the ENSO phenomenon (Timmermann et al., 1999). Climate change prediction models also anticipate regional increases in drought occurrence and intensity across the tropics (Cox et al., 2004, Sheffield and Wood, 2008).

Droughts will not only have potentially dire consequences on food production and human livelihoods, but it will also have direct effects on the global and regional carbon cycles. Drought induced carbon flux changes can take a number of forms including: increased fires (Page et al., 2002), increased vegetation mortality (Clark, 2004, Van Nieuwstadt and Sheil, 
2005, Williamson et al., 2000) and changes in biomass partitioning (Brando et al., 2008, Nepstad et al., 1994). Severe water deficits in plants can among other effects cause catastrophic xylem embolisms, cell dehydration, reduce leaf size, and carbon starvation due to stomata closure (Farooq et al., 2009). Indirectly, stressed ecosystem also become increasingly vulnerability to insects and diseases (McDowell et al., 2008). The extent of drought stress will depend on the mechanisms available to withstand the drier conditions. Plant adaptations and acclimations to these stresses include deep and prolific root systems, osmotic adjustment, increased diffusive resistance, and development of small and succulent leaves (Farooq et al., 2009).

Droughts will not only have aboveground effects but will also have direct and indirect consequences on soil surface and belowground biological processes. Soil moisture changes are known to affect microbial activity, root growth and turnover, decomposition processes, leaf litterfall and aboveground biomass productivity (Davidson et al., 2008). The conceptual diagram of soil $\mathrm{CO}_{2}$ production and transport, shown in Figure 2, is a modification of the model developed by Fang and Montcrieff (1999). The diagram demonstrates how $\mathrm{CO}_{2}$ production from roots and microbial respiration is influenced by environmental conditions (temperature, soil moisture, and soil oxygen). The rate and quantity of $\mathrm{CO}_{2}$ respired at the soil surface is a function of gas diffusivity, which is regulated by soil water contents, soil physical properties and temperature (de Jong and Schappert, 1972). In the event of a drought, both altered soil physical conditions (less water in the soil profile), and vegetation drought responses (changes in litterfall, carbohydrate transfers, root activity and root mortality), will consequently affect belowground $\mathrm{CO}_{2}$ production and emission dynamics.

Tropical soils are estimated to contain nearly one third of the global soil carbon stock (approximately $692 \mathrm{Pg} \mathrm{C}$ ) (excluding permafrost soils and wetlands) (Jobbágy and Jackson, 2000). Therefore, given the natural short residence times of carbon in tropical soil and the higher than average $\mathrm{CO}_{2}$ production, carbon pools in the tropics may be particularly vulnerable to changing soil moisture regimes due to drought (Amundson, 2001, Trumbore, 2006). The increased frequency of severe weather events already observed in recent history, as well as the fact that tropical soils store large amounts of carbon, remind us that a better understanding of soil carbon dynamics in tropical soils in a changing climate is of utmost importance to better predicting future carbon fluxes to the atmosphere. 


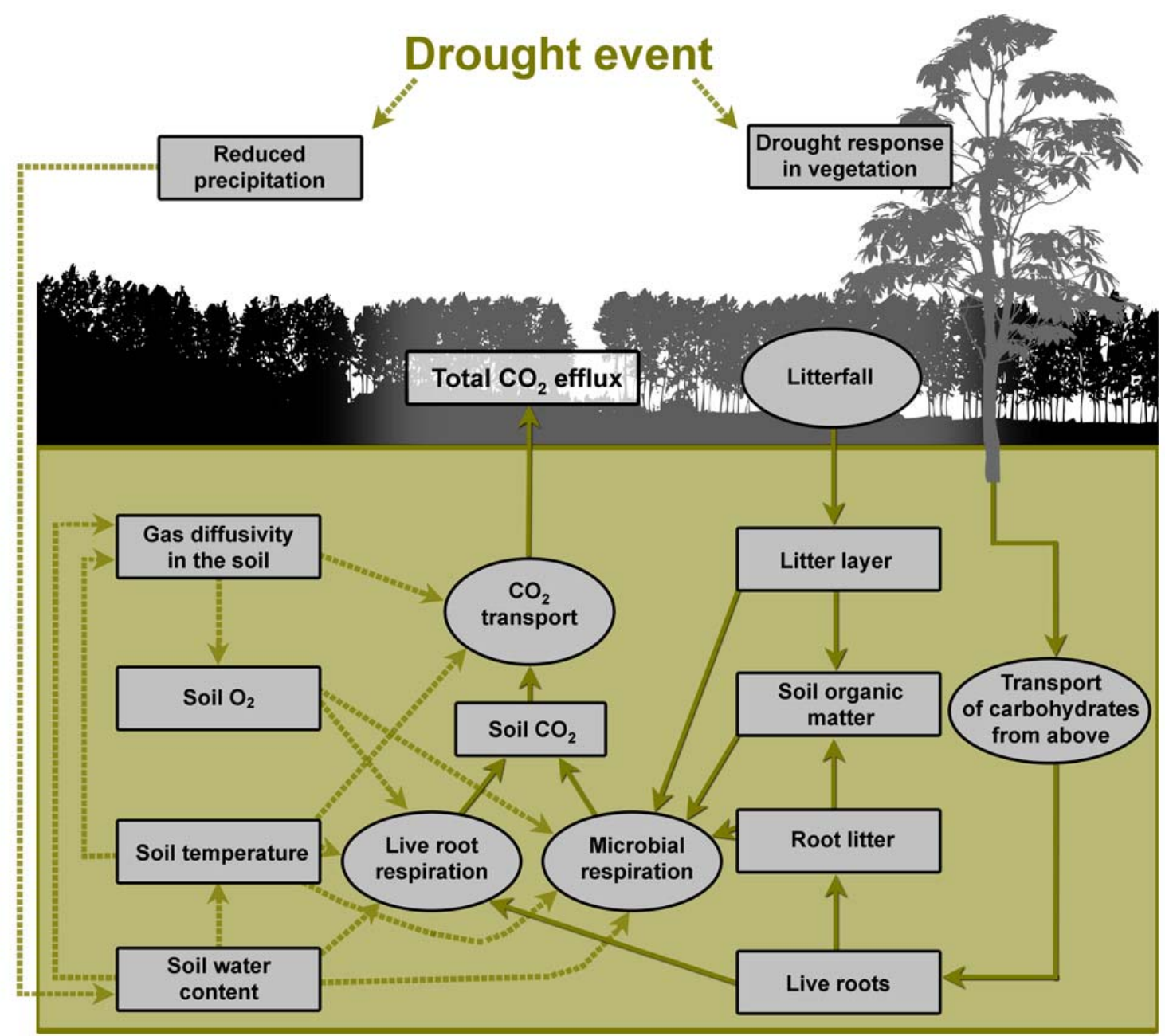

Figure 2: Soil $\mathrm{CO}_{2}$ efflux processes. A conceptual diagram describing drought event influences on soil surface and belowground soil $\mathrm{CO}_{2}$ efflux processes (Modified from Fang and Montcrieff (1999)). Rectangles indicated state variables, ellipses indicate processes; solid lines indicate carbon flows, while dashed lines indicate the influence of environmental conditions on gas transport.

\section{Project objectives and justifications}

In comparison to aboveground biomass estimations, relatively little is known on belowground carbon dynamics despite the fact that they contain five times more carbon. The research undertaken in this dissertation attempts to understand the fate of belowground carbon and the return fluxes to the atmosphere during and after a drought in Sulawesi. We focused on two ecosystems, one in an undisturbed sub-montane tropical forest and a second in a cacao (Theobroma cacao) and Gliricidia sepium agroforestry system. These two ecosystems were selected because of their regional importance to understanding carbon dynamics and, in the case of cacao, because of its rapidly expanding landuse and tremendous economic importance to small-scale farmers. The focus of this study was to examine how an experimental drought affects soil respiration. Specifically the research objectives were as follows: 
1. To characterize the temporal drought effects and ecosystem recuperation on soil respiration and soil $\mathrm{CO}_{2}$ production.

2. To identify the environmental controls regulating soil $\mathrm{CO}_{2}$ efflux and production.

3. To partition $\mathrm{CO}_{2}$ production sources and to identify how they react to drought and rewetting.

4. To identify spatial patterns in soil $\mathrm{CO}_{2}$ efflux.

\section{Experiment design and implementation}

The experiment was conducted within the framework of the Stability of Rainforest Margins (STORMA) project, a multidisciplinary research project funded by the German Science Foundation (DFG) which focused on issues of social and ecological sustainability of the Lore Lindu National Park (Fig. 3).
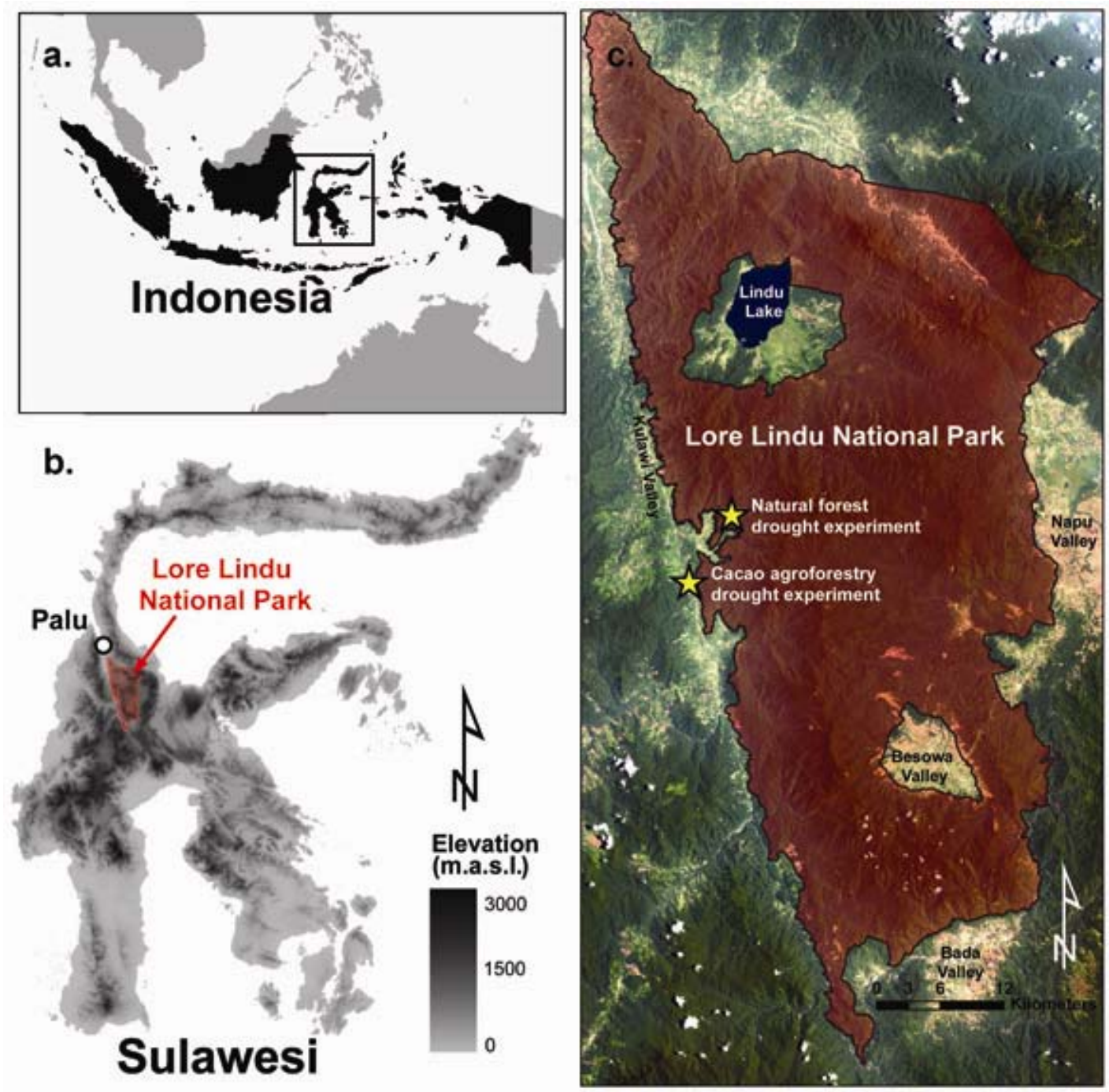

Figure 3: The location of the two drought simulation experiments in (a) Indonesia, (b) Sulawesi, (c) Lore Lindu National Park. 
Two drought simulation experiments were conducted at the western edge of the National Park: one in a cacao / Gliricidia agroforestry plantation and a second in a natural sub-montane tropical forest. To simulate drought effects, we established large-scale throughfall diversion roofs in both ecosystems. The aim of establishing the roofs was to divert incoming water away from the plot and subsequently dry out the underlying soil. The experiment was set up using a stratified random design experiment, whereby soil respiration under the three roof plots was compared with three adjacent control plots which received normal precipitation (Fig. 4 and 5). The roofs were built in the understory of each ecosystem at a height ranging from 1.2 to 2.0 meters above the ground. Each roof experiment consisted of several thousand individual throughfall diversion panels and a series of gutters through which diverted water flowed through to a location down slope of the plot (Fig. 6a and b). The panels which were long and narrow $(0.5 \times 5 \mathrm{~m})$ consisted of a bamboo frame onto which transparent plastic was attached.

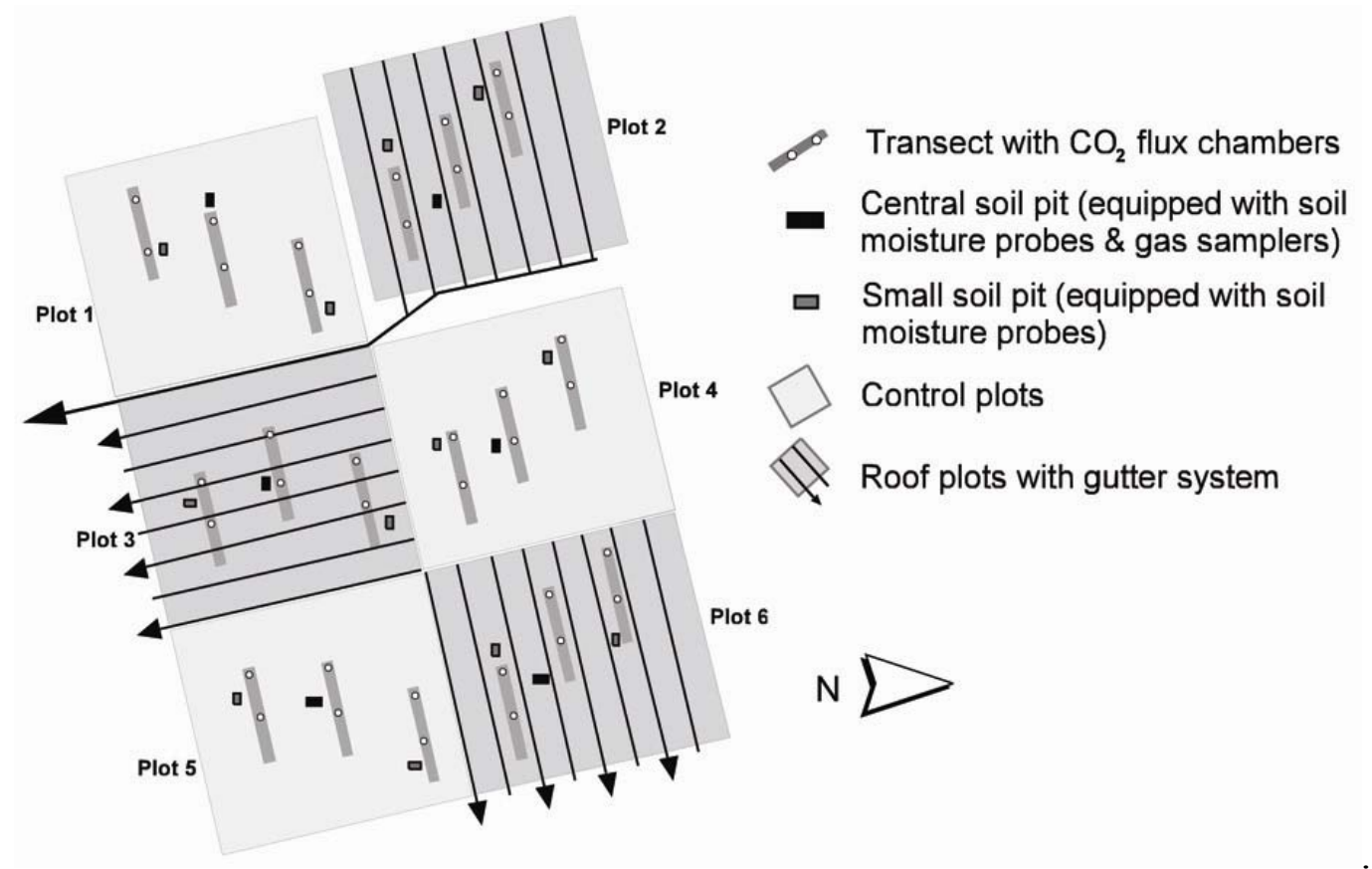

Figure 4: Drought simulation experiment plot layout in the cacao / Gliricidia agroforestry system

Soil $\mathrm{CO}_{2}$ dynamics were measured every two weeks spatially across the experimental plots and vertically within the soil profile down to 2.5 meters. Spatial measurements of soil $\mathrm{CO}_{2}$ efflux were measured at 36 permanently installed measurement chambers spread out across the plots. $\mathrm{CO}_{2}$ efflux was measured using a portable infrared $\mathrm{CO}_{2}$ gas analyzer (IRGA). In the soil profile, soil $\mathrm{CO}_{2}$ production profiles were modeled using soil air $\mathrm{CO}_{2}$ concentrations from different depths in the soil profile and the respective volumetric water content for each 
measurement date in combination with other soil physical properties. The modelling approach utilized was first described by de Jong and Schappert (1972).

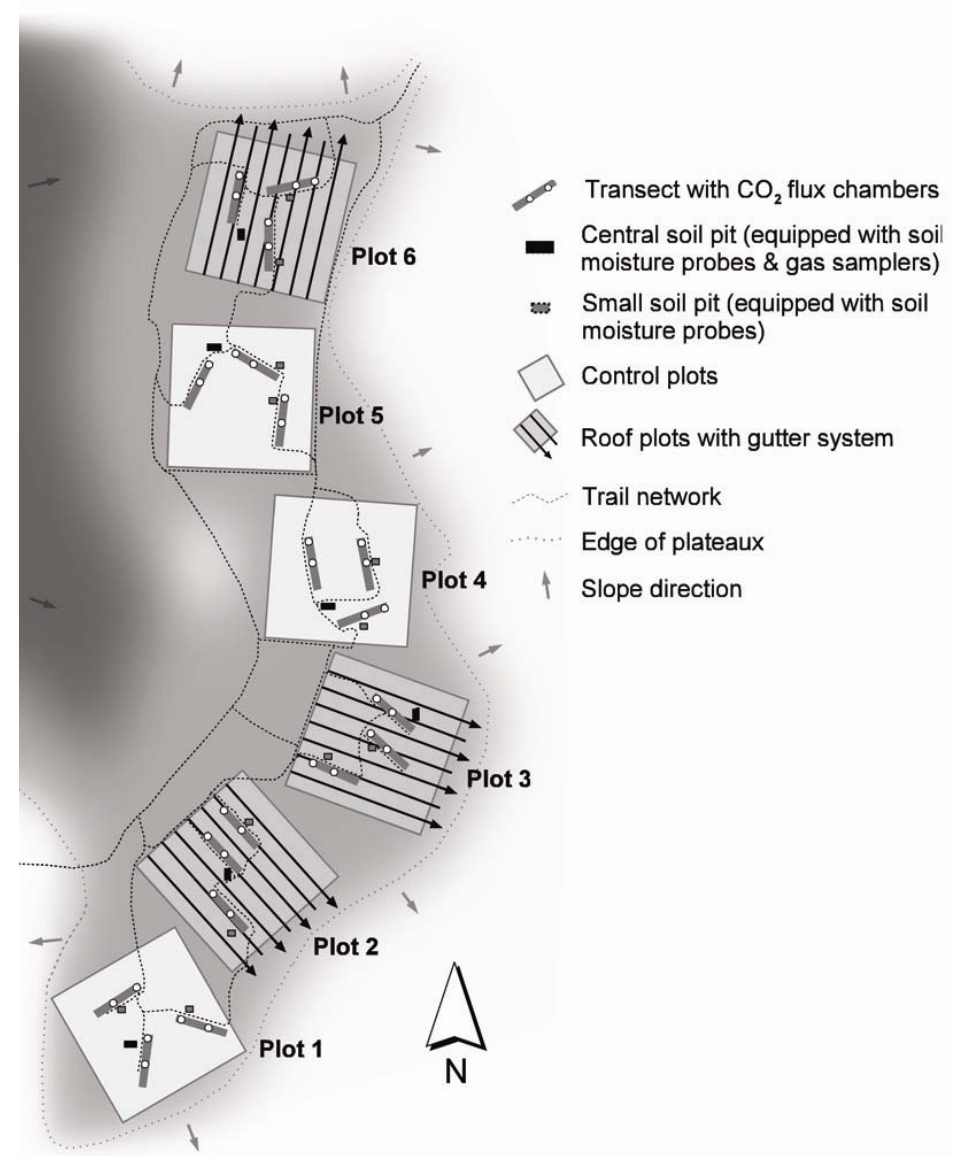

Figure 5: Drought simulation experiment plot layout of the tropical forest site

Furthermore, $\mathrm{CO}_{2}$ contribution from the leaf litter layer was measured at each site in an additional litter removal / litter doubling experiment. At the forest site, an additional experiment was set up to separate belowground respiration into autotrophic and heterotrophic sources using a root trenching and exclusion design.
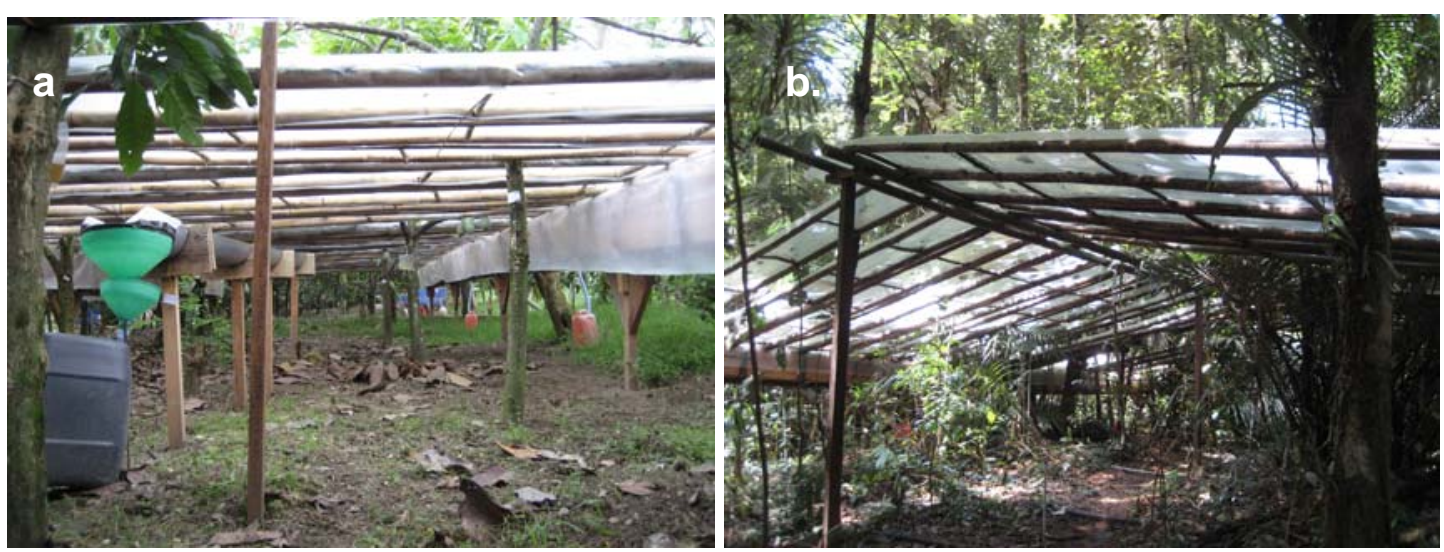

Figure 6: Pictures of the throughfall displacement roof in a) the cacao agroforestry site and $b$ ) the sub-montane tropical forest site 
Further details into the site descriptions and measurement methodologies for each respective site are elaborated on at greater length in the Materials and Methods sections in Chapter 2 for the cacao agroforestry study and Chapter 3 for the natural forest site.

This dissertation constitutes the research from two experiments. Chapter two describes how soil $\mathrm{CO}_{2}$ efflux in a cacao agroforest ecosystem is affected by a 13 months simulated drought. Chapter three reports on belowground $\mathrm{CO}_{2}$ production dynamics spatially as well as vertically in a 24.5 month drought simulation experiment conducted in an undisturbed natural forest. Chapter four is a synthesis of the results of the two studies and attempts to extrapolate results to regional and global scales. 


\section{CHAPTER 2}

SPATIAL AND TEMPORAL EFFECTS OF DROUGHT ON SOIL $\mathrm{CO}_{2}$ EFFLUX IN A CACAO AGROFORESTRY SYSTEM IN SULAWESI, INDONESIA

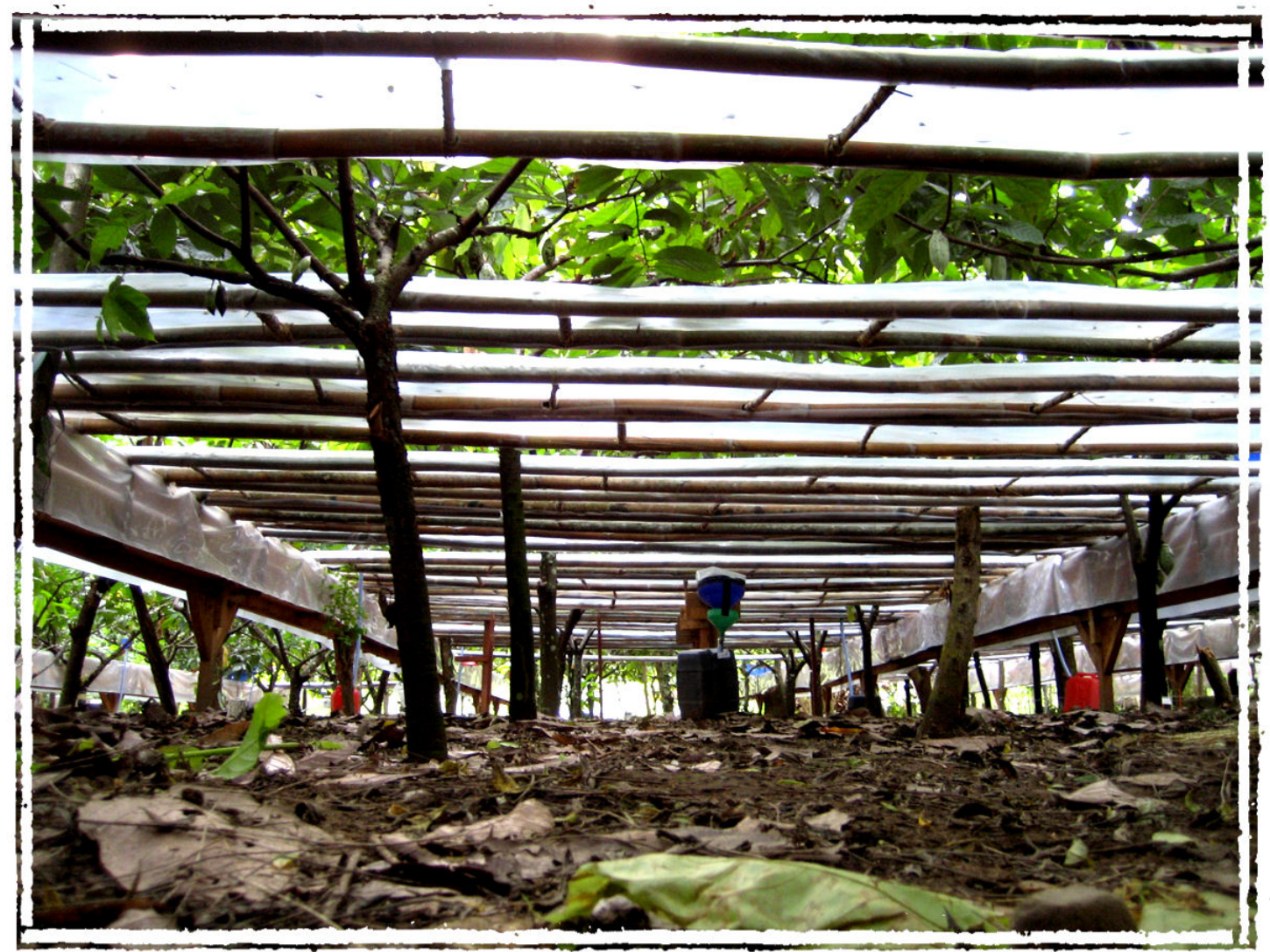

A REVISED VERSION IS PUBLISHED IN BIOGEOSCIENCES, 2010: 7, 1223-1235. 


\title{
SPATIAL AND TEMPORAL EFFECTS OF DROUGHT ON SOIL CO $\mathrm{CO}_{2}$ EFFLUX IN A CACAO AGROFORESTRY SYSTEM IN SULAWESI, INDONESIA
}

\author{
Oliver van Straaten ${ }^{1}$, Edzo Veldkamp ${ }^{1}$, Michael Köhler ${ }^{2}$, Iswandi $\mathrm{Anas}^{3}$ \\ ${ }^{1}$ Buesgen-Institute, Soil Science of Tropical and Subtropical Ecosystems, Georg-August-University of \\ Goettingen, Buesgenweg 2, 37077 Goettingen, Germany \\ ${ }^{2}$ Burckhardt-Institute, Tropical Silviculture and Forest Ecology, Georg-August-University of Goettingen, \\ Buesgenweg 2, 37077 Goettingen, Germany \\ ${ }^{3}$ Department of Soil Science, Faculty of Agriculture, Bogor Agricultural University (IPB), Jl. Raya \\ Pajajaran Bogor 16143, Indonesia
}

\begin{abstract}
Climate change induced droughts pose a serious threat to ecosystems across the tropics and subtropics, particularly to those areas not adapted to natural dry periods. In order to study the vulnerability of cacao (Theobroma cacao) - Gliricidia sepium agroforestry plantations to droughts a large scale throughfall displacement roof was built in Central Sulawesi, Indonesia. In this 19month experiment, we measured soil surface $\mathrm{CO}_{2}$ efflux (soil respiration) in three roof plots compared with three adjacent control plots. Soil respiration rates peaked at intermediate soil moisture and either decreased under increasingly dry conditions (drought induced), or under increasingly wet conditions (as evidenced in control plots). The roof plots exhibited a slight decrease in soil respiration compared to the control plots (average $13 \%$ decrease). The strength of the drought effect was spatially variable - while some measurement chamber sites reacted strongly ("responsive") to the decrease in soil water content (up to $\left.\mathrm{R}^{2}=0.70\right)(\mathrm{n}=11)$, others did not react at all ("non-responsive") $(\mathrm{n}=7)$. A significant correlation was measured between 'responsive' soil respiration chamber sites and sap flux density ratios of cacao $(\mathrm{R}=0.61)$ and Gliricidia $(\mathrm{R}=0.65)$. Leaf litter $\mathrm{CO}_{2}$ respiration decreased as conditions became drier. During dry periods the litter layer contributed approximately $3-4 \%$ of the total $\mathrm{CO}_{2}$ efflux and up to $40 \%$ during wet periods. $\mathrm{A} \mathrm{CO}_{2}$ flush was recorded during the rewetting phase that lasted for approximately two weeks, during which time accumulated labile carbon stocks mineralized. The net effect on soil $\mathrm{CO}_{2}$ emissions over the duration of the experiment was neutral, control plots respired $11.1 \pm 0.5 \mathrm{Mg} \mathrm{C} \mathrm{ha}^{-1} \mathrm{yr}^{-1}$, while roof plots respired $10.5 \pm 0.5 \mathrm{MgC} \mathrm{ha}^{-1} \mathrm{yr}^{-1}$.
\end{abstract}

Keywords: Indonesia, agroforestry, drought, Theobroma cacao, Gliricidia sepium, soil respiration, $\mathrm{CO}_{2}$, soil moisture

Received: 25 November 2009, Accepted: 9 April 2010

Citation: van Straaten O, Veldkamp E, Köhler M, Anas I (2010) Spatial and temporal effects of drought on soil $\mathrm{CO}_{2}$ efflux in a cacao agroforestry system in Sulawesi, Indonesia. Biogeosciences, 7, 1223-1235. 


\section{Introduction}

In recent decades, Indonesia has experienced severe droughts that were related to El Niño Southern Oscillation (ENSO) events (Quinn et al., 1978, Sheffield and Wood, 2008). Some climate prediction models suggest that droughts in Indonesia may become more frequent and more severe in the future (Sheffield and Wood, 2008, Timmermann et al., 1999). Changes in precipitation patterns due to climatic change, including droughts, will have direct effects on agricultural productivity (Sivakumar et al., 2005) and the terrestrial biosphere carbon cycle (Tian et al., 2000). Understanding how ecosystems and specifically carbon dynamics respond to droughts is important given the feedback potentials to the atmosphere from carbon dioxide $\left(\mathrm{CO}_{2}\right)$ emissions. Decreases in precipitation have been shown to affect plant root dynamics, litter fall, soil organic matter decomposition, nutrient mineralization rates, as well as soil aeration - which in turn affects gas diffusion and microbial processes (Davidson et al., 2004). Exactly how an ecosystem will react to drought conditions is largely dependent on the mechanisms it has available to adapt to droughts. The presence or absence of deep root systems is one such mechanism. Studies carried out in tropical forests of Latin America suggest that ecosystems with deep rooted trees are more capable to mitigate drought effects (Davidson et al., 2004, Nepstad et al., 1994).

Droughts in Indonesia pose a potential threat to both natural forest ecosystems and agricultural production systems such as cacao (Theobroma cacao). In the last 25 years, Indonesia has experienced a boom in cocoa production and has since become the third largest producer of cocoa beans worldwide (FAO, 2009). Nearly $80 \%$ of the cocoa beans produced in Indonesia are grown in Sulawesi. It is unknown how well cacao agroforestry plantations are adapted to drought conditions, although a recent socio-economic survey by Keil et al. (2008) in central Sulawesi found that cocoa production is vulnerable to drought. Unlike cacao trees which tend to have a shallow rooting architecture (Kummerow et al., 1982), agroforestry over-story trees such as Gliricidia (Gliricidia sepium) often have deeper root systems.

To date, little has been published on belowground carbon dynamics in agroforestry systems (Bailey et al., 2009, Hergoualc'h et al., 2008, Oelbermann et al., 2006), and as far as we are aware, no soil $\mathrm{CO}_{2}$ efflux measurements have been carried out in tropical agroforestry systems in relation to drought stress.

In a replicated experiment, we investigated how a cacao - Gliricidia agroforestry plantation in central Sulawesi, Indonesia reacted to an experimental drought. In an earlier 
paper by Schwendenmann et al. (2010) it was shown that this agroforest was surprisingly resilient to drought conditions which was explained by a combination of complementary use of soil water resources and acclimation. Here we report how the experimental drought affected soil $\mathrm{CO}_{2}$ production and efflux. The specific research objectives for this study were twofold:

1. To determine how belowground carbon dynamics (specifically $\mathrm{CO}_{2}$ production) reacted to a simulated drought and the subsequent rewetting phase.

2. To identify the controls driving $\mathrm{CO}_{2}$ efflux.

At the beginning of the experiment we suspected that this agroforestry system would be vulnerable to drought stress and we hypothesized that soil respiration rates will show strong decreases across the plantation with the severity and duration of the drought affecting the degree of the $\mathrm{CO}_{2}$ drought response. Furthermore, if the drought becomes so severe that there is significant root mortality $\mathrm{CO}_{2}$ emissions may become more difficult to predict, as a drought-induced reduction in root and heterotrophic respiration may be compensated for by an increase in dead roots which may lead to an increase in decomposition. Finally, during the rewetting phase following the drought we expected a strong increase in $\mathrm{CO}_{2}$ production in the drought plots.

\section{Materials and Methods}

\subsection{Site description}

The drought simulation experiment was conducted in a seven year old cacao agroforestry plantation on the western periphery of the Lore Lindu National Park $\left(1.552^{\circ} \mathrm{S}, 120.020^{\circ} \mathrm{E}\right)$ in Central Sulawesi, Indonesia at an elevation of $560 \mathrm{~m}$ above sea level (a.s.1.). Established in December 2000, the plantation was composed of a Gliricidia (Gliricidia sepium (Jacq.) Kunth ex Steud.) overstory $\left(\sim 330\right.$ trees $\left.\mathrm{ha}^{-1}\right)$ and a cacao (Theobroma cacao L) understory $\left(\sim 1,030\right.$ trees $\left.\mathrm{ha}^{-1}\right)$. The ground was largely devoid of undergrowth herbs and grasses except for a few patches of grass in open areas. We selected a site that was located on a gentle slope $\left(8-12^{\circ}\right)$, where the ground water table $(>4.5 \mathrm{~m})$ was deeper than the tree rooting zone. The region experiences two mild rainy seasons per year. The average annual precipitation at the Gimpu meteorological station (417 m.a.s.l.) five kilometres south of the experimental site was $2092 \mathrm{~mm}$. The mean annual temperature for 2002 - 2006 was $25.5^{\circ} \mathrm{C}$ (Schwendenmann et al., 2010). 
The soil has been classified as a Cambisol with a sandy loam texture (Leitner and Michalzik, unpublished data). The top $75 \mathrm{~cm}$ of soil has a relatively homogeneous texture, a stone content of $15-25 \%$ and a bulk density of $1.31 \pm 0.06 \mathrm{~g} \mathrm{~cm}^{-3}$. Below $75 \mathrm{~cm}$ the sub-soil is heterogeneous, made up of saprolite, irregular granitic rock fragments embedded in a quartz-feldspar rich loam. The bulk density of the subsoil is $1.56 \pm 0.08 \mathrm{~g} \mathrm{~cm}^{-3}$. Soil chemical and physical properties for the control and roof plot soil profiles are summarized in Table 1.

While the majority of cacao fine roots (diameter $<2 \mathrm{~mm}$ ) are predominantly concentrated at the soil surface (top $40 \mathrm{~cm}$ ), the Gliricidia fine roots penetrate to greater depths (Moser et al., 2010). Fine roots of both tree species extended to a maximum depth of $2.4 \mathrm{~m}$.

Table 1: Soil physical and chemical properties: Bulk density, soil texture, carbon and nitrogen content, effective cation exchange capacity (ECEC) and $\mathrm{pH}\left(\mathrm{H}_{2} \mathrm{O}\right)$ of the $250 \mathrm{~cm}$ soil profile. The values are means $\pm 1 \mathrm{SE}, \mathrm{n}=3$.

\begin{tabular}{|c|c|c|c|c|c|c|c|c|}
\hline Depth & $\begin{array}{l}\text { Bulk density } \\
\left(\mathrm{g} \mathrm{cm}^{-3}\right)\end{array}$ & Sand (\%) & $\begin{array}{l}\text { Soil Texture } \\
\text { Silt (\%) }\end{array}$ & Clay (\%) & $\begin{array}{l}\text { Carbon } \\
\left(\mathrm{g} \mathrm{kg}^{-1}\right)\end{array}$ & $\begin{array}{l}\text { Nitrogen } \\
\left(\mathrm{g} \mathrm{kg}^{-1}\right)\end{array}$ & $\begin{array}{c}\text { ECEC } \\
\left(\mathrm{cmol} \mathrm{kg}^{-1}\right)\end{array}$ & $\begin{array}{l}\text { Soil pH } \\
\left(\mathrm{H}_{2} \mathrm{O}\right)\end{array}$ \\
\hline \multicolumn{9}{|c|}{ Control Plots } \\
\hline-5 & $1.27 \pm 0.02$ & $60.7 \pm 1.7$ & $25.7 \pm 0.2$ & $13.6 \pm 1.6$ & $16.6 \pm 1.4$ & $1.5 \pm 0.1$ & $7.7 \pm 1.3$ & $5.8 \pm 0.3$ \\
\hline-10 & $1.31 \pm 0.01$ & $54.1 \pm 1.8$ & $31.1 \pm 2.4$ & $14.8 \pm 1.3$ & $10.7 \pm 1.3$ & $1.0 \pm 0.1$ & $6.6 \pm 0.6$ & $5.6 \pm 0.1$ \\
\hline-20 & $1.33 \pm 0.02$ & $55.1 \pm 1.0$ & $28.3 \pm 0.9$ & $16.5 \pm 0.5$ & $6.4 \pm 0.1$ & $0.6 \pm 0.0$ & $7.3 \pm 1.3$ & $5.9 \pm 0.3$ \\
\hline-40 & $1.31 \pm 0.02$ & $53.9 \pm 0.0$ & $25.5 \pm 1.2$ & $20.6 \pm 1.2$ & $4.2 \pm 0.3$ & $0.4 \pm 0.0$ & $5.3 \pm 0.8$ & $5.7 \pm 0.0$ \\
\hline-75 & $1.36 \pm 0.08$ & $58.6 \pm 2.8$ & $22.2 \pm 2.6$ & $19.2 \pm 1.8$ & $3.4 \pm 0.3$ & $0.4 \pm 0.0$ & $7.5 \pm 1.9$ & $5.9 \pm 0.0$ \\
\hline \multicolumn{9}{|c|}{ Roof Plots } \\
\hline-5 & $1.23 \pm 0.02$ & $59.6 \pm 0.9$ & $28.4 \pm 1.8$ & $12.1 \pm 2.7$ & $16.3 \pm 2.4$ & $1.6 \pm 0.2$ & $9.9 \pm 1.2$ & $6.0 \pm 0.1$ \\
\hline-10 & $1.26 \pm 0.02$ & $55.9 \pm 1.1$ & $28.2 \pm 1.8$ & $16.0 \pm 1.1$ & $14.5 \pm 2.9$ & $1.3 \pm 0.2$ & $9.0 \pm 0.3$ & $6.4 \pm 0.1$ \\
\hline-20 & $1.30 \pm 0.0$ & $56.2 \pm 3.0$ & $28.1 \pm 2.6$ & $15.6 \pm 0.4$ & $7.7 \pm 1.1$ & $0.7 \pm 0.1$ & $7.9 \pm 0.1$ & $6.3 \pm 0.0$ \\
\hline-40 & $1.32 \pm 0.04$ & $56.1 \pm 1.7$ & $27.4 \pm 2.6$ & $16.6 \pm 1.6$ & $4.6 \pm 0.1$ & $0.4 \pm 0.0$ & $5.6 \pm 0.2$ & $6.0 \pm 0.1$ \\
\hline-75 & $1.37 \pm 0.01$ & $57.3 \pm 1.2$ & $23.4 \pm 1.5$ & $19.3 \pm 0.9$ & $3.3 \pm 0.2$ & $0.4 \pm 0.0$ & $7.9 \pm 2.5$ & $5.8 \pm 0.3$ \\
\hline
\end{tabular}

\subsection{Experimental design}

We established the experiment in a stratified random design using six plots in a one hectare area. Each plot was $40 \times 35 \mathrm{~m}$ in dimension. Three plots were left undisturbed (control) while three treatment plots, hereafter called "roof plots", were used to simulate drought conditions. In the "roof" plots we built a transparent roof below the plantation canopy to divert throughfall away from the plot. The roof was built at a height of approximately $1.2 \mathrm{~m}$ and consisted of approximately 1500 individual bamboo panels 
$(0.5 \times 4.6 \mathrm{~m})$, which were covered by polyethylene plastic sheets. The roof was initially $60 \%$ closed, with small gaps located around the tree stems and between some panels. In January 2008 , the roof closure was further increased to approximately $80 \%$, by building smaller panels in order to close some of the bigger gaps. Runoff was diverted into a series of wooden, plastic lined gutters and channelled down-slope of the plot. Every two weeks leaf litter that accumulated on the roof panels was transferred back to the soil surface. Temperature, humidity and incident radiation under the panels were unaffected by the establishment of the roof. Along the perimeter of each plot we dug a $0.4 \mathrm{~m}$ trench and lined it with plastic so as to prevent lateral and surface water flows from entering the plots.

All measurements were made within a 'core zone' $(30 \times 25 \mathrm{~m})$ in the plot, leaving a $5 \mathrm{~m}$ buffer zone along the inside of the plot boundary to avoid edge effects. Per plot one central soil pit $(0.8 \mathrm{~m}$ width $\times 1.6 \mathrm{~m}$ length $\times 3.0 \mathrm{~m}$ depth $)$ was dug and equipped with gas samplers, thermocouples and soil moisture probes. Three parallel transects per plot were set up within the 'core zone' for soil $\mathrm{CO}_{2}$ flux measurements.

The experiment began on 27 January, 2007 with a one month (33 days) baseline evaluation phase (pre-treatment) during which conditions prior to roof closure were evaluated. The roof was closed on 1 March, 2007 and remained closed for 13 months (404 days). After the roof opening on 10 April, 2008 measurements continued for an additional five months to 27 August, 2008 (141 days) to monitor the recovery of the ecosystem.

\subsection{Soil surface $\mathrm{CO}_{2}$ efflux measurements}

We determined the soil surface $\mathrm{CO}_{2}$ efflux (soil respiration) using dynamic closed chambers (Parkinson, 1981, Norman et al., 1992). At each plot, two circular polyvinyl chloride (PVC) chamber bases $\left(0.045 \mathrm{~m}^{2}\right.$ area, $0.15 \mathrm{~m}$ height $)$ were deployed in each of three parallel transects. In total six chambers were established per plot. Chamber bases were embedded $1-2 \mathrm{~cm}$ into the soil surface. At each chamber base we removed all emergent vegetation prior to measurement, and fanned the air above the chamber for at least one minute in order to bring the soil surface $\mathrm{CO}_{2}$ concentrations to near atmospheric concentrations. We also measured the chamber height at three places around the chamber base to get a good estimate of air volume within the chamber headspace. Measurements entailed attaching a chamber hood (12 cm height) tightly to the chamber base. Air in the headspace was subsequently circulated by a small battery-operated pump at a rate of $0.8 \mathrm{~L} \mathrm{~min}^{-1}$ between the chamber and an infrared $\mathrm{CO}_{2}$ gas analyzer (IRGA) (LI-800; Li-Cor Inc., Lincoln, NE, USA). The chamber was closed for 5 min $30 \mathrm{sec}$. Atmospheric 
pressure was maintained within the chamber during measurements by using a small metal vent $(0.1 \mathrm{~cm}$ in diameter and $2.5 \mathrm{~cm}$ length $)$ installed on top of the chamber hood. Carbon dioxide concentrations were recorded every 5 seconds using a datalogger (Campbell CR800). A two point calibration of the infrared $\mathrm{CO}_{2}$ gas analyzer was done in the laboratory between measurement campaigns. The first point calibration was with a 'zero' standard gas, which was created by removing $\mathrm{CO}_{2}$ from the air by running air in a loop through a scrubber column of soda lime (4-8 mesh). The second point calibration was made using a $\mathrm{CO}_{2}$ standard gas $(700 \mathrm{ppm}$, Deuste Steininger $\mathrm{GmbH}$, Mühlhausen, Germany), while a third $\mathrm{CO}_{2}$ standard gas (356 ppm, Deuste Steininger $\mathrm{GmbH}$, Mühlhausen, Germany) was used to test the quality and accuracy of the calibration.

Soil respiration flux was calculated from a 2.5 minute time window during which $\mathrm{CO}_{2}$ concentrations increased linearly; the coefficient of determination $\left(\mathrm{R}^{2}\right)$ usually exceeded 0.993. Simultaneous to $\mathrm{CO}_{2}$ efflux sampling we measured soil and air temperature with a handheld electronic thermometer (Greisinger GMH 3210) with a $12 \mathrm{~cm}$ measurement probe, and soil moisture using a portable TDR (Campbell Scientific Hydrosense - CS620) unit at 3 points around the chamber base. Measurements were made every two weeks between 8 am and $5 \mathrm{pm}$. The sequence in which plots were measured was randomized during each sampling campaign to minimize effects from diurnal fluctuations. In total, 36 soil respiration measurements were made per sampling campaign using the portable infrared $\mathrm{CO}_{2}$ gas analyzer. During the experimental period we carried out 47 measurement campaigns. Due to an equipment failure with the IRGA we did not measure soil respiration in August 2007.

To study the contribution of leaf litter to $\mathrm{CO}_{2}$ efflux, we randomly selected six experiment chambers in the control plots. At each of the selected sites, two additional chambers were installed directly adjacent to the 'main' chamber ( $<1 \mathrm{~m}$ away). We removed litter from one chamber and placed it into the second chamber. The 'main' chamber was left undisturbed and used as a control. The difference in $\mathrm{CO}_{2}$ efflux between the three chambers was compared. Measurements were made during 36 measurement campaigns.

\subsection{Soil air $\mathrm{CO}_{2}$ concentrations and soil moisture depth profiles}

Gas samples for $\mathrm{CO}_{2}$ concentration analyses were collected from one central soil pit per plot. Samples were taken on a bi-weekly basis in tandem with the soil respiration measurements. The gas samplers consisted of thin stainless-steel tubes $(1 \mathrm{~mm}$ inner 
diameter), where one end was perforated with small holes and the other end was fitted with an airtight septum holder. The samplers were inserted horizontally into the soil profile at $10,20,40,75,150$ and $250 \mathrm{~cm}$ depths. Samplers in the top $75 \mathrm{~cm}$ were $1 \mathrm{~m}$ in length, while the samplers inserted at greater depths $(150$ and $250 \mathrm{~cm})$ were slightly longer $(1.5 \mathrm{~m})$ to take into consideration the diffusion losses near the soil pit wall. Each sampler was equipped with a thermocouple (Type K) at its tip so that temperature could be recorded at the time of sampling with a handheld unit (Greisinger GMH 3210). Before taking a gas sample, $5 \mathrm{~mL}$ of air was extracted and discarded to clear the sampler of any stagnant 'dead' air. We took the gas samples by connecting a pre-evacuated, air-tight glass vial $(50 \mathrm{~mL})$ to the sampler's septum holder with a syringe needle and short flexible plastic tube and then opened a two-way stop valve on the glass vial to suck in the gas sample. A sample was also taken at the soil surface by sticking a polypropylene syringe (with $5 \mathrm{~cm}$ needle) into the ground and drawing a sample.

Samples were analyzed in a laboratory at Tadulako University in Palu, Sulawesi, within 72 hours after collection in the field. We measured the $\mathrm{CO}_{2}$ concentration of each sample using a gas chromatograph (GC) (GC-11, Delsi Instruments, Suresnes, France) with thermal conductivity detector (TCD). Sample $\mathrm{CO}_{2}$ concentrations were calculated by comparing the integrated peak areas to that of two known standard gas concentrations $(0.07 \%$ and $3.5 \%$, Deuste Steininger GmbH, Mühlhausen, Germany), to make a two point calibration.

Additional to the $\mathrm{CO}_{2}$ concentration and temperature measurements, we also measured volumetric soil water content using time domain reflectometry (TDR) sensors (Campbell CS616) in three soil pits per plot. TDR sensors were installed adjacent to each gas sampler, in the central pit, by inserting them into the undisturbed soil at the end of a $30 \mathrm{~cm}$ hole dug horizontally into the soil pit wall. Soil moisture was recorded hourly using a datalogger (Campbell CR1000). Due to high rock content in the soil we could not install TDR sensors in three plots at $250 \mathrm{~cm}$ depth. Using undisturbed soil samples we calibrated the water content measurements using the methodology described by Veldkamp \& O'Brien (2000). Volumetric water content was recalculated to soil matric potential using soil water retention curves developed by (van Straaten, unpublished data).

Soil $\mathrm{CO}_{2}$ concentration measurements were made during 46 field campaigns, in tandem with the IRGA soil respiration measurements. One additional field campaign was missed due to a large landslide that limited access to the site with the gas sampling equipment. 


\section{$2.5 \mathrm{CO}_{2}$ leaching losses}

To determine whether the downward flux from leaching accounted for an important $\mathrm{CO}_{2}$ exit pathway losses we calculated the amount of $\mathrm{CO}_{2}$ dissolved in water and linked it with modeled drainage estimates. According to Henry's Law, $\mathrm{CO}_{2}$ dissolved in water is proportional to the partial pressure of $\mathrm{CO}_{2}$ above the solution and the $\mathrm{CO}_{2}$ Bunsen absorption coefficient. When carbon dioxide dissolves into water it can produce two possible reactions (Eq. 1 and 2). The solubilisation of $\mathrm{CO}_{2}$ gas:

$$
\mathrm{CO}_{2}(\text { gas }) \rightarrow \mathrm{CO}_{2}(\mathrm{aq})
$$

and hydration of $\mathrm{CO}_{2}(\mathrm{aq})$ to form carbonic acid

$$
\mathrm{CO}_{2}(\mathrm{aq})+\mathrm{H}_{2} \mathrm{O} \rightarrow \mathrm{H}_{2} \mathrm{CO}_{3}(\mathrm{aq})
$$

However, given the low proportion of $\mathrm{H}_{2} \mathrm{CO}_{3}$ (aq) relative to $\mathrm{CO}_{2}$ (aq) it is possible to lump their concentrations together with Henry's law. The dissolved $\mathrm{CO}_{2}$ was calculated as follows:

$$
\mathrm{M}-\mathrm{CO}_{2} \mathrm{w}=\mathrm{CO}_{2} \mathrm{a} \times \mathrm{VWC} \times \mathrm{B}
$$

whereby $M-C_{2} w$ is the $\mathrm{CO}_{2}$ content dissolved in the liquid phase $\left(\mathrm{g} \mathrm{CO}_{2} \mathrm{~m}^{-3}\right), \mathrm{CO}_{2} a$ is the partial pressure of $\mathrm{CO}_{2}$ (concentration) in the soil air $\left(\mathrm{g} \mathrm{CO}_{2} \mathrm{~m}^{-3}\right)$ at atmospheric air pressure, VWC is the soil's volumetric water content and $B$ is the Bunsen solubility coefficient for $\mathrm{CO}_{2}$. The Bunsen coefficient is the volume of gas that can be absorbed by one cubic meter of water at standard atmospheric air pressure, at $24^{\circ} \mathrm{C}$, the $\mathrm{CO}_{2}$ Bunsen coefficient is $0.7771 \mathrm{~g} \mathrm{~m}^{-3}$.

Dissolved $\mathrm{CO}_{2}$ was calculated for the gas samples taken at $250 \mathrm{~cm}$ soil depth and interpolated to give daily values of dissolved $\mathrm{CO}_{2}$ throughout the duration of the experiment period. Subsequently, dissolved $\mathrm{CO}_{2}$ was multiplied with daily modeled soil water drainage to determine $\mathrm{CO}_{2}$ leaching losses. Soil drainage from roof and control plots were modeled using HYDRUS 1D (Šimůnek et al., 2008) with measured transpiration rates, net precipitation and soil water contents as input. The method has been described in greater detail in Köhler et al.(in preparation). Leaching losses were calculated only from 
10 February, 2007 to 5 June, 2008 because of the shorter time frame in which soil water drainage was modeled.

\subsection{Isotope analysis}

To identify the origin of the high $\mathrm{CO}_{2}$ concentrations in deep soil, ${ }^{13} \mathrm{CO}_{2}$ isotope signatures were measured. One soil air sample was taken from each plot at $250 \mathrm{~cm}$ depth, stored in airtight, stainless steel vials and transported to the Centre for Stable Isotope Research and Analysis (KOSI, Georg-August-University of Goettingen, Germany) for analysis using a Isotope Ratio Mass Spectrometer (Finnigan MAT Delta Plus, Bremen, Germany). The isotopic signature can indicate whether the $\mathrm{CO}_{2}$ was produced either biologically or from geological origins.

\subsection{Data analysis}

We divided the experiment into three time periods: pre-treatment, treatment and posttreatment. Throughout the experiment, roof plot measurements were compared to adjacent control plots to decipher roof plot ecosystem drought response from normal fluctuations. Individual soil $\mathrm{CO}_{2}$ efflux chamber measurements were averaged for each plot at each measurement date and logarithmically transformed to normalize data distributions. The significance of the drought effect difference was tested using mixed linear effects models for the three time periods mentioned above, the overall experiment period (from start to finish) and an extra time interval during the last three months of the treatment period during which drought effects were most pronounced. In the model, the desiccation treatment was considered a fixed effect while the measurement day (from day 1 to day 579) and plot were considered as random effects. Differences were considered significant if $\mathrm{P} \leq 0.05$. Additionally, temporal autocorrelation in this time series $\mathrm{CO}_{2}$ flux dataset was corrected for by using a first order autoregressive model.

The relationship between soil $\mathrm{CO}_{2}$ efflux and soil moisture (at $10 \mathrm{~cm}$ ), soil surface temperature, Gliricidia and cacao sap flux densities, and chamber distance from tree stem were tested with linear regressions. All statistical analyses were done using the statistical package R version 2.8.1 (R Development Core Team, 2008). 


\section{Results}

\subsection{Volumetric soil water content and soil temperature}

During the pre-treatment phase, volumetric soil water content of all six experiment plots were in the same range for each respective sampling depth (Fig. 1c). Approximately ten days after roof closure, soil water contents began to diverge between the control and roof plots. Soil moisture contents in the plots under the roof decreased simultaneously at all depths, apart from the depth of $250 \mathrm{~cm}$ depth which began drying out only after a period of two and a half months. Although gaps in the roof did allow some throughfall to enter, the water recharge was limited to the upper soil layers and was never enough to recharge the soil under roof to control plot levels. A natural drought in January - February 2008 reduced soil water contents in both roof and control plots. The drying effect was recorded down to $250 \mathrm{~cm}$ depth in the control plots. Minimum soil water contents in the roof plots were experienced during this dry spell. Upon roof opening in April 2008, soil water contents in the roof plots quickly rose to near control plot levels.

Soil surface temperature exhibited little fluctuation throughout the duration of the experimental period, ranging from a minimum temperature of $21.8^{\circ} \mathrm{C}$ to a maximum temperature of $24.8^{\circ} \mathrm{C}$. The average soil temperature at $5 \mathrm{~cm}$ depth was unaffected by the roof installation, measuring $23.2 \pm 0.8^{\circ} \mathrm{C}$ and $23.0 \pm 0.7^{\circ} \mathrm{C}($ mean $\pm \mathrm{SD})$ for the roof and control plots respectively. At $250 \mathrm{~cm}$ depth, soil temperatures were slightly higher than at the surface and averaged $24.0 \pm 0.4^{\circ} \mathrm{C}($ mean $\pm \mathrm{SD})$.

\subsection{Soil surface $\mathrm{CO}_{2}$ efflux}

Soil surface $\mathrm{CO}_{2}$ efflux was highly variable in both space and time. Spatially, the average coefficient of variation of the 18 roof plot and 18 control plot chambers was $52 \%$ and $46 \%$ respectively over the period of the experiment. The temporal coefficient of variation for individual chamber measurements was slightly lower in the control plots (40\%) in comparison to the treatment plots $(53 \%)$. 


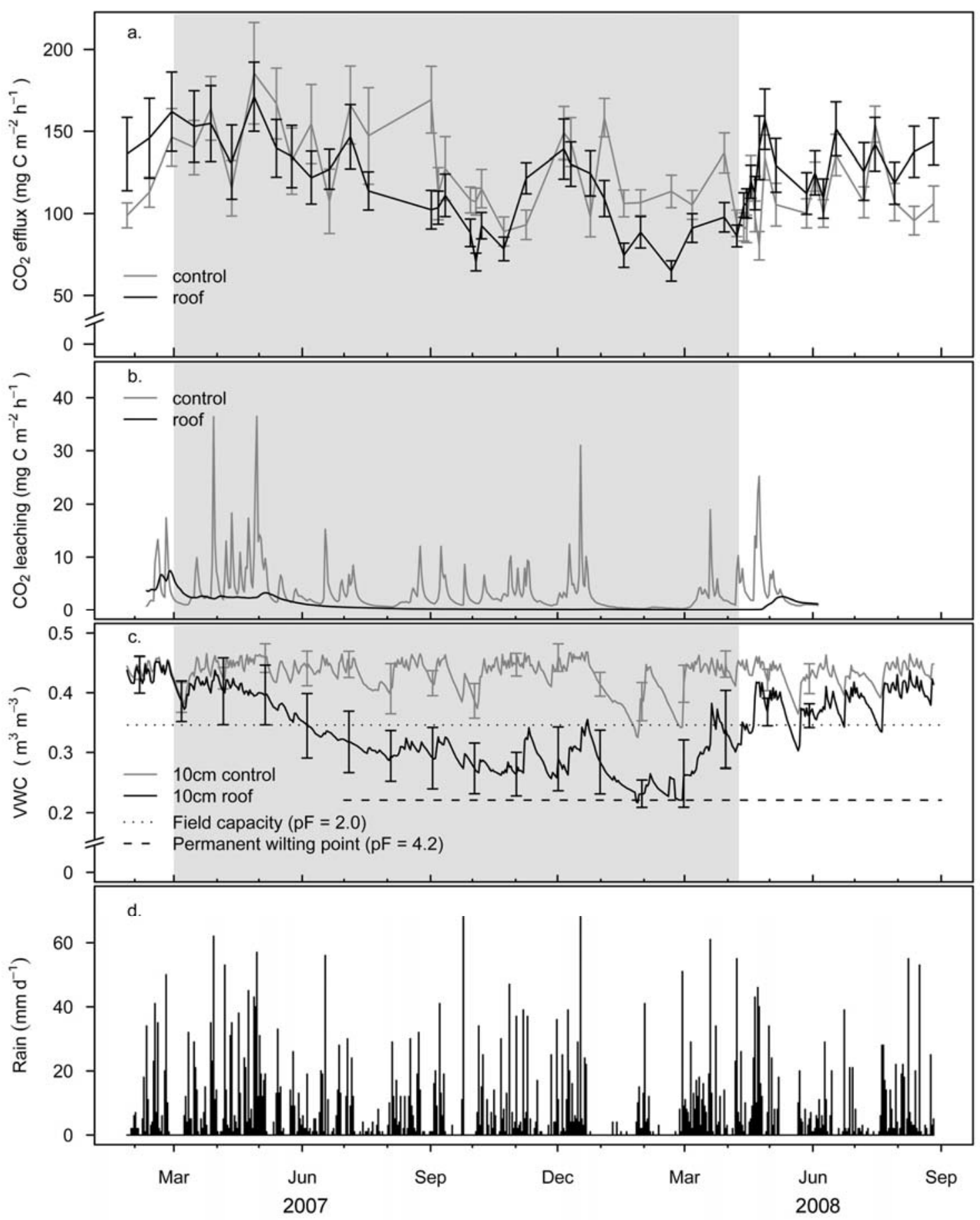

Figure 1: Soil $\mathrm{CO}_{2}$ efflux, soil $\mathrm{CO}_{2}$ leaching, volumetric water content and daily precipitation. (a) Average soil surface $\mathrm{CO}_{2}$ efflux in control and roof plots, (b) average soil $\mathrm{CO}_{2}$ leaching losses in control and roof plots, (c) average volumetric water content at $10 \mathrm{~cm}$ soil depth in control and roof plots and (d) daily precipitation. Error bars indicate $\pm 1 \mathrm{SE}$. The shaded area indicates the period of roof closure.

During the pre-treatment phase, soil $\mathrm{CO}_{2}$ efflux measurements were slightly higher in the roof plots as compared to the control, though not statistically significant $(P=0.13)$ (Fig. 1a and Table 2). Following roof closure in March 2007, soil respiration rates in the roof plots began a slow decline that lasted until late October 2007. From early November 
until mid December 2007, roof plot respiration rates experienced a short lived peak followed by a second decline during a two month natural drought. Respiration rates reached a minimum level in late February 2008 and thereafter remained low until roof opening in April 2008. During the treatment period the control plots did not exhibit any distinct temporal trend although soil $\mathrm{CO}_{2}$ efflux variability was highest during the first half year and less so thereafter.

The overall differences in average soil $\mathrm{CO}_{2}$ efflux between the control and the roof plots were relatively minor. Soil $\mathrm{CO}_{2}$ efflux declined only slightly in the control plots in comparison to the roof plots. On average, roof plots respired $13 \%$ less than the control plots, although this difference was not statistically significant $(\mathrm{P}=0.16)$. In the last three months of the simulated drought the onset of a natural dry spell in combination with improved roof closure resulted in a further decline in the soil $\mathrm{CO}_{2}$ efflux. During this time the roof plots averaged $75 \%$ of the control soil respiration, a decline of $25 \%(\mathrm{P}<0.05)$. Immediately upon roof opening, in April 2008, we measured a flush of soil $\mathrm{CO}_{2}$. Within three days, soil $\mathrm{CO}_{2}$ efflux exceeded the control plots by more than $15 \%$. Over the next five months the average roof plot $\mathrm{CO}_{2}$ efflux remained consistently above control plot efflux levels, although the treatment means were not significantly different. One roof plot chamber was removed from the analysis shortly after roof opening as it suddenly began producing very high $\mathrm{CO}_{2}$ fluxes.

The cumulative $\mathrm{CO}_{2}$ respired from control and roof plots was not significantly different, indicating the drought had a $\mathrm{CO}_{2}$ neutral effect. The cumulative $\mathrm{CO}_{2}$ flux from the 579-day experiment was $17.5 \pm 0.75 \mathrm{Mg} \mathrm{Cha}^{-1}$ and $16.6 \pm 0.74 \mathrm{Mg} \mathrm{Cha}^{-1}$ for the control and roof plots respectively. Annually this equates to $11.1 \pm 0.5 \mathrm{Mg} \mathrm{C} \mathrm{ha}^{-1} \mathrm{yr}^{-1}$ for the control plot and $10.5 \pm 0.5 \mathrm{MgC} \mathrm{ha}^{-1} \mathrm{yr}^{-1}$ for the roof plot.

Although the overall drought response in the roof plots was relatively moderate, 11 of the 18 efflux chambers in the roof plots exhibited stronger drought effects than the others (Fig. 3). Drought effects were most pronounced at chamber sites already producing high $\mathrm{CO}_{2}$ before the roof closure. We used the coefficient of determination $\left(\mathrm{R}^{2}\right)$ of a linear regression between $\mathrm{CO}_{2}$ efflux and the soil moisture as an index of drought response (hereafter called the "drought response index") and plotted it spatially (Fig. 2). The drought response appeared to be localized, as some chamber sites measured strong relationships to soil water content changes (up to $\mathrm{R}^{2}=0.70$ ), while other chambers often located nearby measured little to no response to decreasing soil water contents. 
Over the course of the 19-month measurement period, no distinguishable seasonal patterns in either precipitation (Fig. 1d) or in air temperature were measured (data not shown).

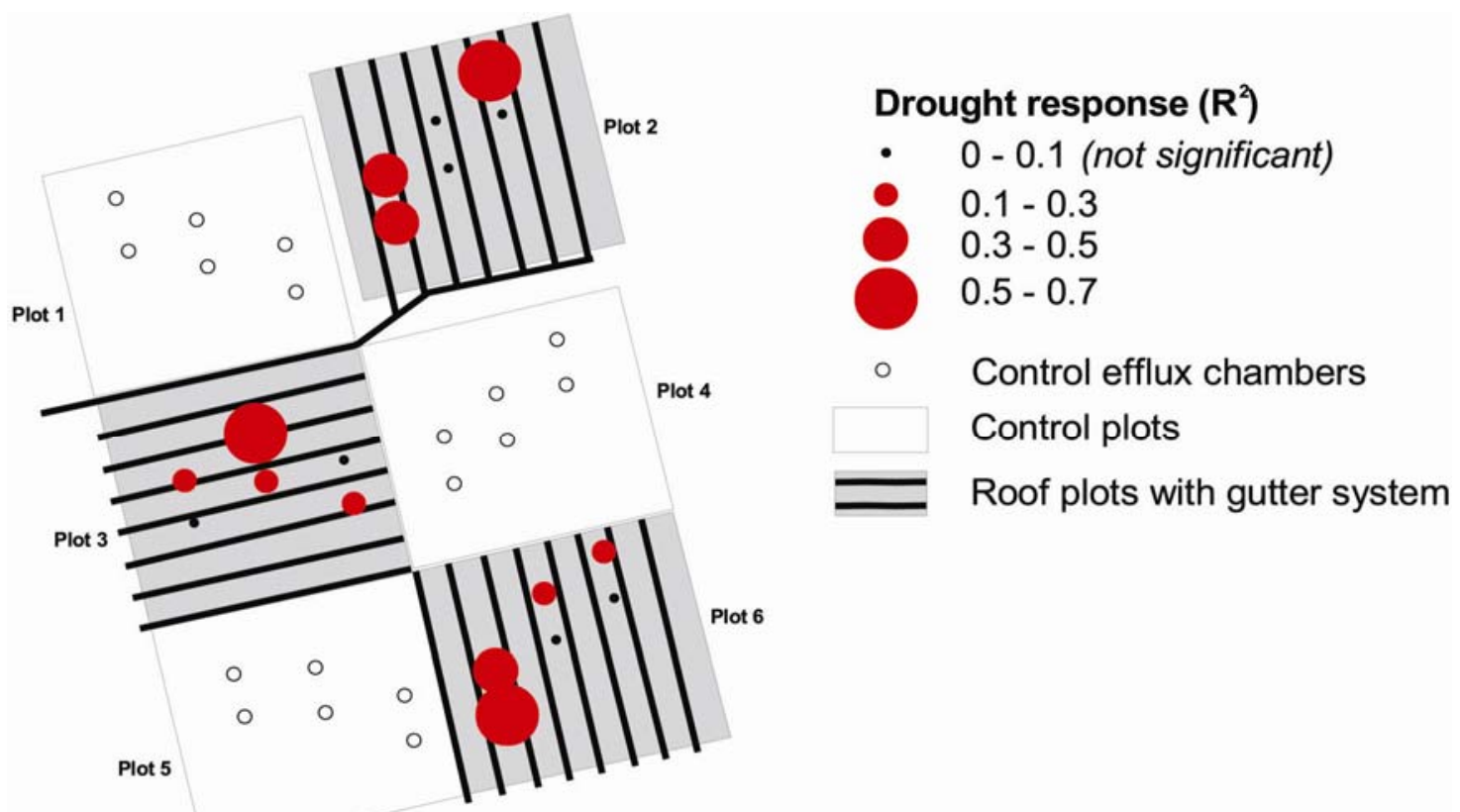

Figure 2: Drought responsiveness map. Schematic of cacao agroforestry plot layout and response of $\mathrm{CO}_{2}$ flux chambers to soil water content changes. The coefficient of determination $\left(\mathrm{R}^{2}\right)$ for the $\mathrm{CO}_{2}$ efflux to volumetric water content was used as index of how strong a chamber reacted to changes in soil moisture.

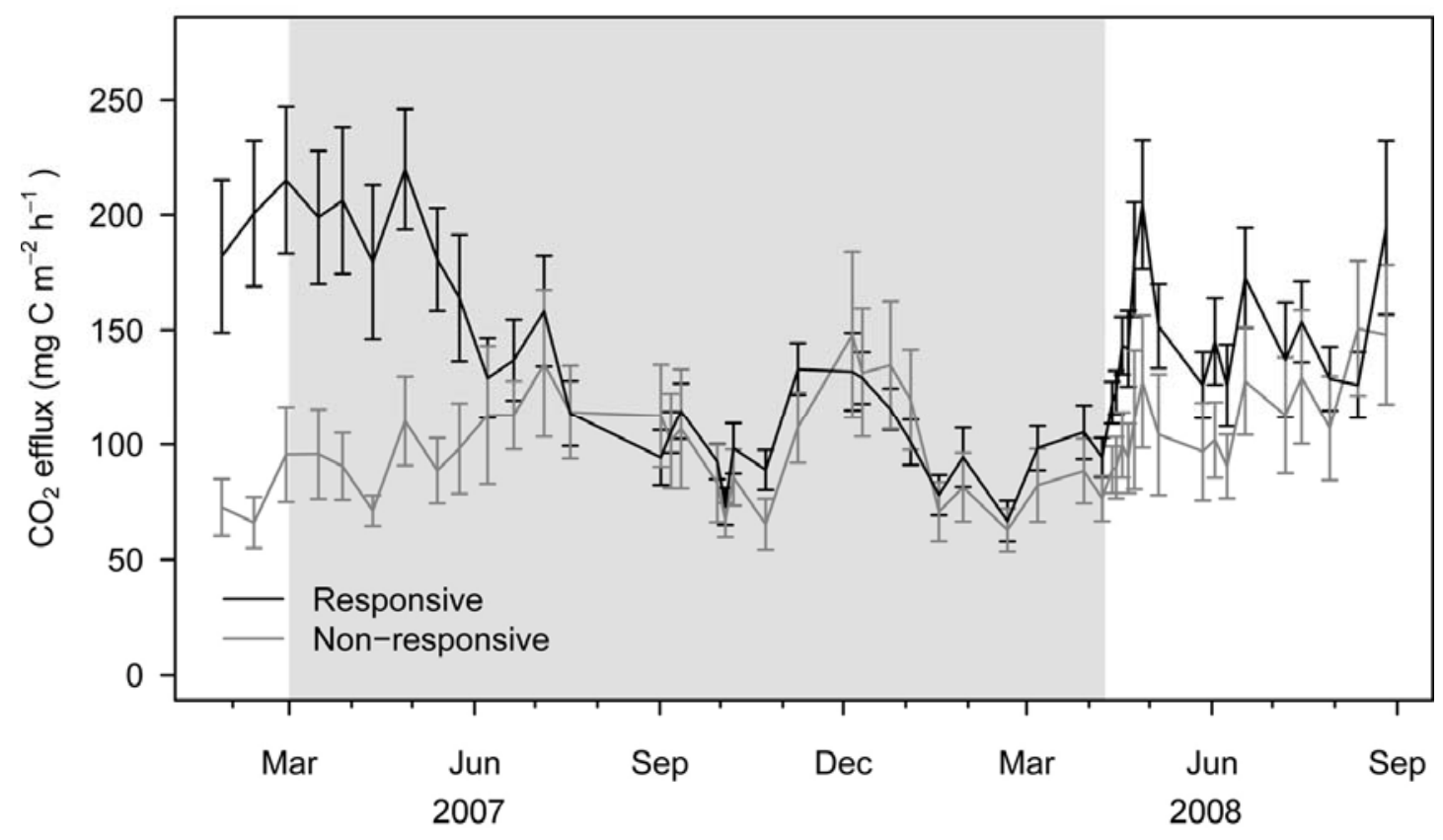

Figure 3: Drought responsive versus non-responsive $\mathrm{CO}_{2}$ efflux comparison in the roof plots. Error bars indicate $\pm 1 \mathrm{SE}$. The shaded area indicates the period of roof closure. 
Table 2: Experiment soil surface $\mathrm{CO}_{2}$ efflux $\left(\mathrm{mg} \mathrm{C} \mathrm{m}^{-2} \mathrm{~h}^{-1}\right)$ and soil air $\mathrm{CO}_{2}$ concentrations (\%) for different soil depths for the pre-treatment, treatment, post-treatment. Mean value \pm 1 SE. $n=$ number of sampling campaigns.

\begin{tabular}{|c|c|c|c|c|c|c|c|c|c|c|c|c|}
\hline & \multirow[b]{2}{*}{$\mathrm{n}$} & \multicolumn{2}{|c|}{ Pre-treatment } & \multicolumn{3}{|c|}{ Treatment } & \multicolumn{3}{|c|}{ Post-treatment } & \multicolumn{3}{|c|}{ Entire experiment period } \\
\hline & & Control & Roof & $\mathrm{n}$ & Control & Roof & $\mathrm{n}$ & Control & Roof & $\mathrm{n}$ & Control & Roof \\
\hline $\mathrm{CO}_{2}$ efflux $\left(\mathrm{mg} \mathrm{C} \mathrm{m}^{-2} \mathrm{~h}^{-1}\right)$ & 3 & $118.0 \pm 15.6$ & $142.5 \pm 31.8$ & 28 & $131.8 \pm 7.6$ & $114.7 \pm 6.8$ & 16 & $112.0 \pm 6.4$ & $129.4 \pm 8.5$ & 47 & $126.2 \pm 5.4$ & $119.5 \pm 5.4$ \\
\hline Soil $\mathrm{CO}_{2}$ concentrations $(\%)$ & 3 & & & 28 & & & 15 & & & 46 & & \\
\hline$-5 \mathrm{~cm}$ & & $0.4 \pm 0.2$ & $0.5 \pm 0.3$ & & $1.3 \pm 0.2$ & $0.6 \pm 0.0$ & & $1.3 \pm 0.2$ & $1.2 \pm 0.1$ & & $1.2 \pm 0.1$ & $0.8 \pm 0.1$ \\
\hline$-10 \mathrm{~cm}$ & & $3.7 \pm 0.9$ & $5.1 \pm 0.6$ & & $2.4 \pm 0.2$ & $1.2 \pm 0.1$ & & $2.8 \pm 0.2$ & $2.7 \pm 0.1$ & & $2.6 \pm 0.2$ & $1.8 \pm 0.1$ \\
\hline$-20 \mathrm{~cm}$ & & $5.7 \pm 0.4$ & $6.0 \pm 0.5$ & & $4.0 \pm 0.2$ & $1.7 \pm 0.2$ & & $5.0 \pm 0.2$ & $3.8 \pm 0.1$ & & $4.4 \pm 0.1$ & $2.4 \pm 0.1$ \\
\hline$-40 \mathrm{~cm}$ & & $6.1 \pm 0.5$ & $7.8 \pm 0.4$ & & $4.9 \pm 0.2$ & $2.4 \pm 0.2$ & & $5.5 \pm 0.3$ & $4.5 \pm 0.1$ & & $5.1 \pm 0.2$ & $3.2 \pm 0.2$ \\
\hline$-75 \mathrm{~cm}$ & & $7.1 \pm 0.5$ & $8.5 \pm 0.4$ & & $6.3 \pm 0.2$ & $3.2 \pm 0.2$ & & $7.4 \pm 0.3$ & $5.5 \pm 0.1$ & & $6.6 \pm 0.2$ & $4.0 \pm 0.2$ \\
\hline$-150 \mathrm{~cm}$ & & $9.9 \pm 0.3$ & $10.3 \pm 0.4$ & & $9.2 \pm 0.2$ & $5.7 \pm 0.3$ & & $10.1 \pm 0.2$ & $7.6 \pm 0.2$ & & $9.5 \pm 0.1$ & $6.3 \pm 0.2$ \\
\hline$-250 \mathrm{~cm}$ & & $12.4 \pm 0.2$ & $12.3 \pm 0.7$ & & $11.6 \pm 0.2$ & $8.7 \pm 0.3$ & & $12.2 \pm 0.1$ & $10.6 \pm 0.1$ & & $11.8 \pm 0.1$ & $9.3 \pm 0.2$ \\
\hline
\end{tabular}




\subsection{Controls regulating $\mathrm{CO}_{2}$ efflux}

Soil $\mathrm{CO}_{2}$ efflux exhibited a strong relationship with soil moisture. $\mathrm{CO}_{2}$ efflux peaked under intermediate soil moisture contents (between $\mathrm{pF} 1$ and 2) and decreased when conditions became either wetter $\left(\mathrm{R}^{2}=0.34, \mathrm{P}<0.01\right)$, or drier $\left(\mathrm{R}^{2}=0.71, \mathrm{P}<0.01\right)$ (Fig. 4). The rate of change (slope) at the wet end of the moisture spectrum was steeper than at the drier end. Soil temperature had little effect on soil $\mathrm{CO}_{2}$ efflux. Only in the control plots did we find a significant, but weak, positive relationship with soil temperature $\left(R^{2}=0.16\right.$, $\mathrm{P}<0.01)$. There was no relationship found between soil moisture and soil temperature.

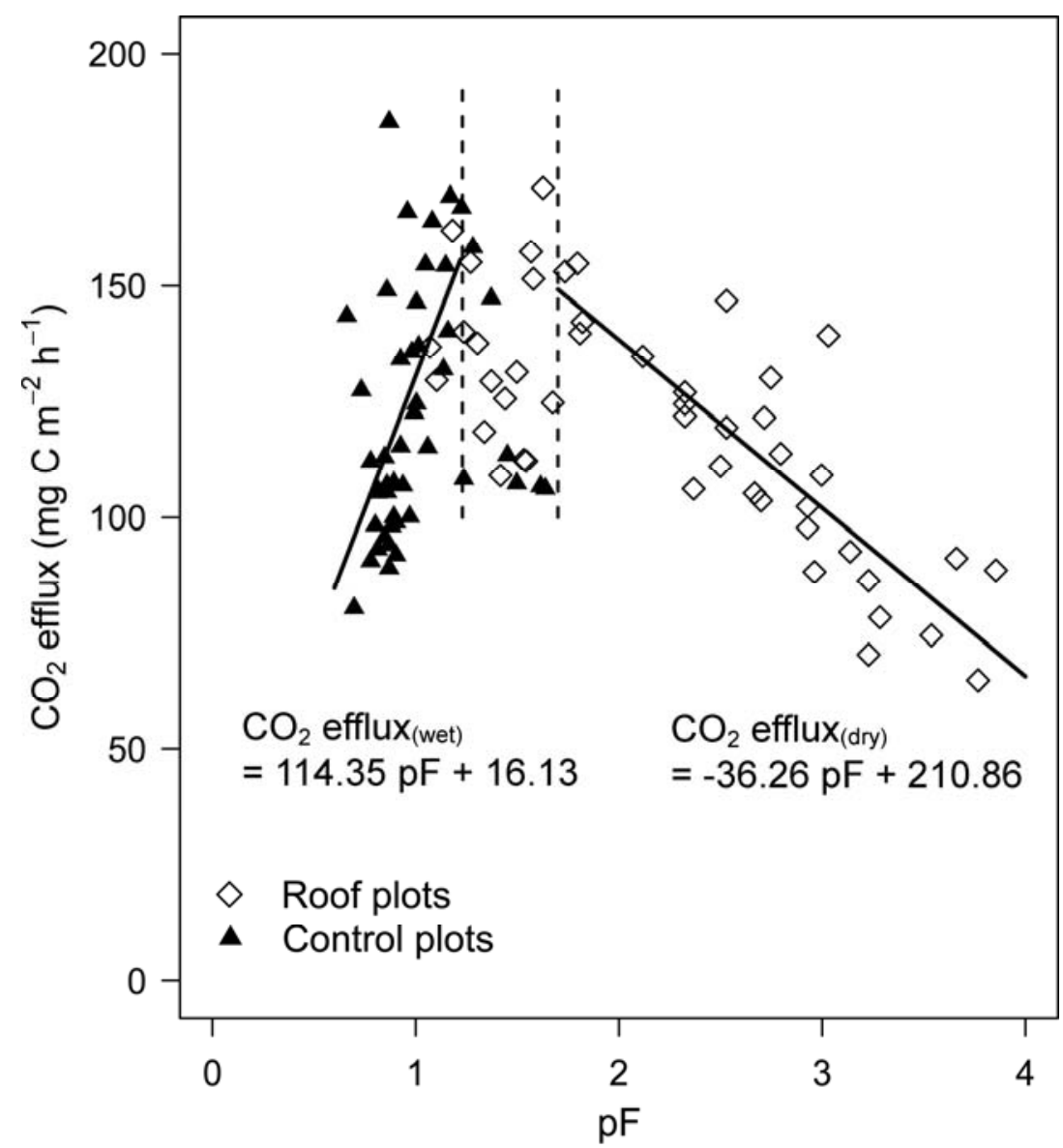

Figure 4: Relationship between soil water potential (pF) and soil $\mathrm{CO}_{2}$ efflux (Wet relationship: $R^{2}=0.34, P<0.001$, Dry relationship: $R^{2}=0.71, P<0.001$ ) showing the average soil $\mathrm{CO}_{2}$ efflux measurements from roof and control plots for each measurement campaign. Each point represents the average of $18 \mathrm{CO}_{2}$ efflux measurements. Soil moisture was measured using TDR sensors from three soil pits per plot embedded horizontally at $10 \mathrm{~cm}$ soil depth.

A weak diurnal pattern was detected in soil respiration, whereby $\mathrm{CO}_{2}$ efflux was lowest early in the early morning before 8 am and rose steadily throughout the day reaching a 
maximum in the late afternoon between 4 and $6 \mathrm{pm}$ (Table 3). No night-time measurements were made.

Table 3: Diurnal soil $\mathrm{CO}_{2}$ efflux, soil temperature and air temperature during daytime hours. The mean values are \pm 1 SE.

\begin{tabular}{|c|c|c|c|c|c|c|c|}
\hline & Time & $\mathrm{n}$ & $\begin{array}{c}\text { Roof Plot } \\
\text { Soil CO } \mathrm{CO}_{2} \text { flux } \\
{\left[\mathrm{mg} \mathrm{C} \mathrm{m}^{-2} \mathrm{~h}^{-1}\right]}\end{array}$ & $\mathrm{n}$ & $\begin{array}{l}\text { Control Plot } \\
\text { Soil } \mathrm{CO}_{2} \text { flux } \\
{\left[\mathrm{mg} \mathrm{C} \mathrm{m}^{-2} \mathrm{~h}^{-1}\right]} \\
\end{array}$ & $\begin{array}{c}\text { Soil } \\
\text { temperature } \\
{\left[{ }^{\circ} \mathrm{C}\right]} \\
\end{array}$ & $\begin{array}{c}\text { Air } \\
\text { temperature } \\
{\left[{ }^{\circ} \mathrm{C}\right]} \\
\end{array}$ \\
\hline Early morning & 06:00-08:00 & 19 & $95.0 \pm 12.5$ & 9 & $107.6 \pm 12.6$ & $23.1 \pm 0.2$ & $22.7 \pm 0.5$ \\
\hline Mid morning & 08:00-10:00 & 238 & $110.0 \pm 3.8$ & 267 & $109.3 \pm 3.3$ & $22.9 \pm 0.0$ & $24.3 \pm 0.1$ \\
\hline Late morning & $10: 00-12: 00$ & 318 & $124.0 \pm 4.0$ & 292 & $118.6 \pm 3.6$ & $23.0 \pm 0.0$ & $26.6 \pm 0.1$ \\
\hline Early afternoon & $12: 00-14: 00$ & 149 & $127.9 \pm 6.0$ & 141 & $125.3 \pm 6.0$ & $23.3 \pm 0.0$ & $27.6 \pm 0.1$ \\
\hline Mid afternoon & $14: 00-16: 00$ & 71 & $132.8 \pm 9.6$ & 85 & $142.0 \pm 8.6$ & $23.8 \pm 0.1$ & $26.6 \pm 0.2$ \\
\hline Late afternoon & 16:00-18:00 & 36 & $131.9 \pm 12.8$ & 36 & $138.3 \pm 12.8$ & $24.2 \pm 0.1$ & $25.4 \pm 0.1$ \\
\hline
\end{tabular}

Soil respiration was found to decrease with distance from cacao tree stems $\left(\mathrm{R}^{2}=0.22\right.$, $\mathrm{P}<0.01$ ), but showed not relationship with distance from Gliricidia trees. $\mathrm{CO}_{2}$ efflux measurement chambers were established between 1.1 and 2.1 meters from the nearest tree. In the roof plots, the $\mathrm{CO}_{2}$ drought response index declined with distance from cacao tree stems $\left(\mathrm{R}^{2}=0.23, \mathrm{P}=0.053\right)$, but showed no relationship with distance to Gliricidia tree stems

\subsection{Leaf litter respiration}

The leaf litter layer contributed on average $16.8 \%$ of the total respired $\mathrm{CO}_{2}$ efflux. Although we did not measure the moisture of the litter layer directly there is a strong indication that respiration rates were positively related to the moisture regime of the leaf litter. Soil moisture probes located at $10 \mathrm{~cm}$ soil depth showed a positive linear relationship $\left(\mathrm{R}^{2}=0.20, \mathrm{P}<0.01\right)$ between soil moisture and the leaf litter $\mathrm{CO}_{2}$ efflux contribution. In other words, when conditions were dry $\mathrm{CO}_{2}$ efflux from the litter was low and did not contribute much to the overall soil flux $(\sim 3-4 \%$ of the total flux). However, when conditions were wet, leaf litter $\mathrm{CO}_{2}$ efflux increased and became an important $\mathrm{CO}_{2}$ production source contributing up to $40 \%$ of the overall $\mathrm{CO}_{2}$ efflux. The leaf litter $\mathrm{CO}_{2}$ contribution to the overall control plot $\mathrm{CO}_{2}$ flux over the duration of experiment is shown in Figure 5. 


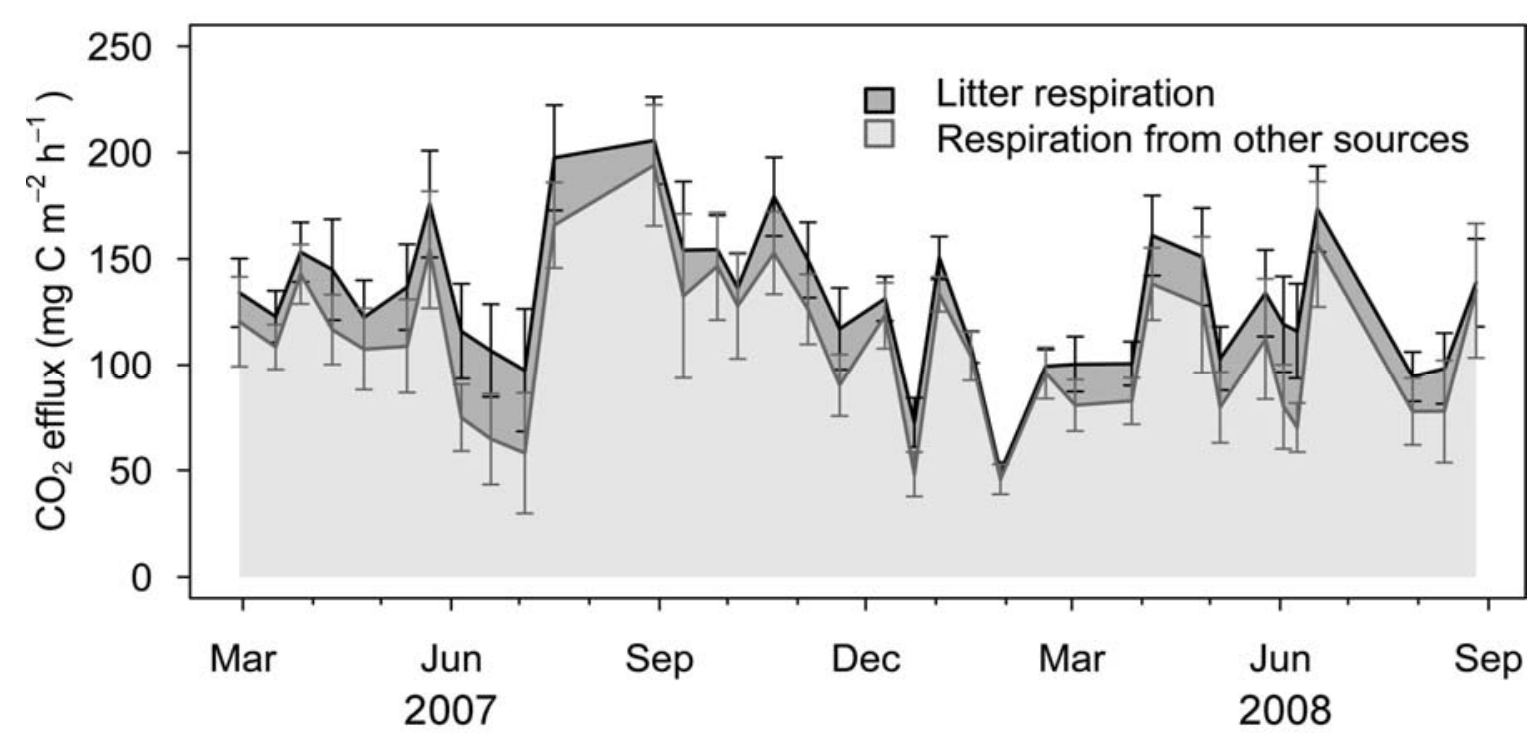

Figure 5: $\mathrm{CO}_{2}$ efflux from leaf litter contribution study in the control plots. The dark grey colour indicates the $\mathrm{CO}_{2}$ production derived from leaf litter, while the light grey colour denotes the $\mathrm{CO}_{2}$ production from within the soil profile from other sources. The error bars indicate the standard error of the six measurements per sampling date.

\subsection{Soil profile $\mathrm{CO}_{2}$ concentrations}

Soil $\mathrm{CO}_{2}$ concentrations increased with soil depth, displaying an exponential shape in concentration rise (Table 2$)$, where concentrations near the soil surface $(0-10 \mathrm{~cm})$ were relatively low and increased rapidly with depth (between $20-75 \mathrm{~cm}$ depth) and finally approached an asymptote at deeper soil depths $(150-250 \mathrm{~cm})$. Average $\mathrm{CO}_{2}$ concentrations in the control plots over duration of the experiment period at $250 \mathrm{~cm}$ were $11.8 \%$ - this is more than 300 times higher than atmospheric $\mathrm{CO}_{2}$. The highest recorded $\mathrm{CO}_{2}$ concentration was $15.3 \%$ in October 2007 in one of the control plots.

During the pre-treatment period soil $\mathrm{CO}_{2}$ concentrations in the control and treatment plots were similar for each respective soil depth (Fig. 6). Upon roof closure, $\mathrm{CO}_{2}$ concentrations in the roof plots began to decline in tandem with the drying out of the soil profile. $\mathrm{CO}_{2}$ concentrations declined steadily over the 13-month treatment period and reached a minimum level in the last month of the induced drought. $\mathrm{CO}_{2}$ concentrations reached lows of between $17 \%$ (at $10 \mathrm{~cm}$ depth) and $52 \%$ (at $250 \mathrm{~cm}$ depth) of the control plot levels. During the driest period of the simulated drought the soil $\mathrm{CO}_{2}$ concentration depth profile was nearly linear in shape, supposedly saturating at a deeper depth than from which we sampled. Although $\mathrm{CO}_{2}$ concentrations in the control plots remained relatively constant throughout the treatment period, a sharp drop was measured at all soil depths in January - February 2008, during a phase of natural drought. When we opened the roof in 
April 2008, $\mathrm{CO}_{2}$ concentrations rose quickly; within a one month period $\mathrm{CO}_{2}$ concentrations at all depths rose to near control plot levels whereby $\mathrm{CO}_{2}$ concentrations at shallower depths rebounded faster than in the subsoil. Thereafter, $\mathrm{CO}_{2}$ concentrations levelled off, and remained lower than the control plot until the end of the experiment in August 2008.

The $\delta \mathrm{C}^{13}$ isotope signature of the six $\mathrm{CO}_{2}$ gas samples was $-23.63 \pm 0.19 \%$ (mean $\pm \mathrm{SD}$ ) indicating that the $\mathrm{CO}_{2}$ present in the soil profile is biologically produced and most likely produced by $\mathrm{C}_{3}$ plants - e.g. cacao and Gliricidia.

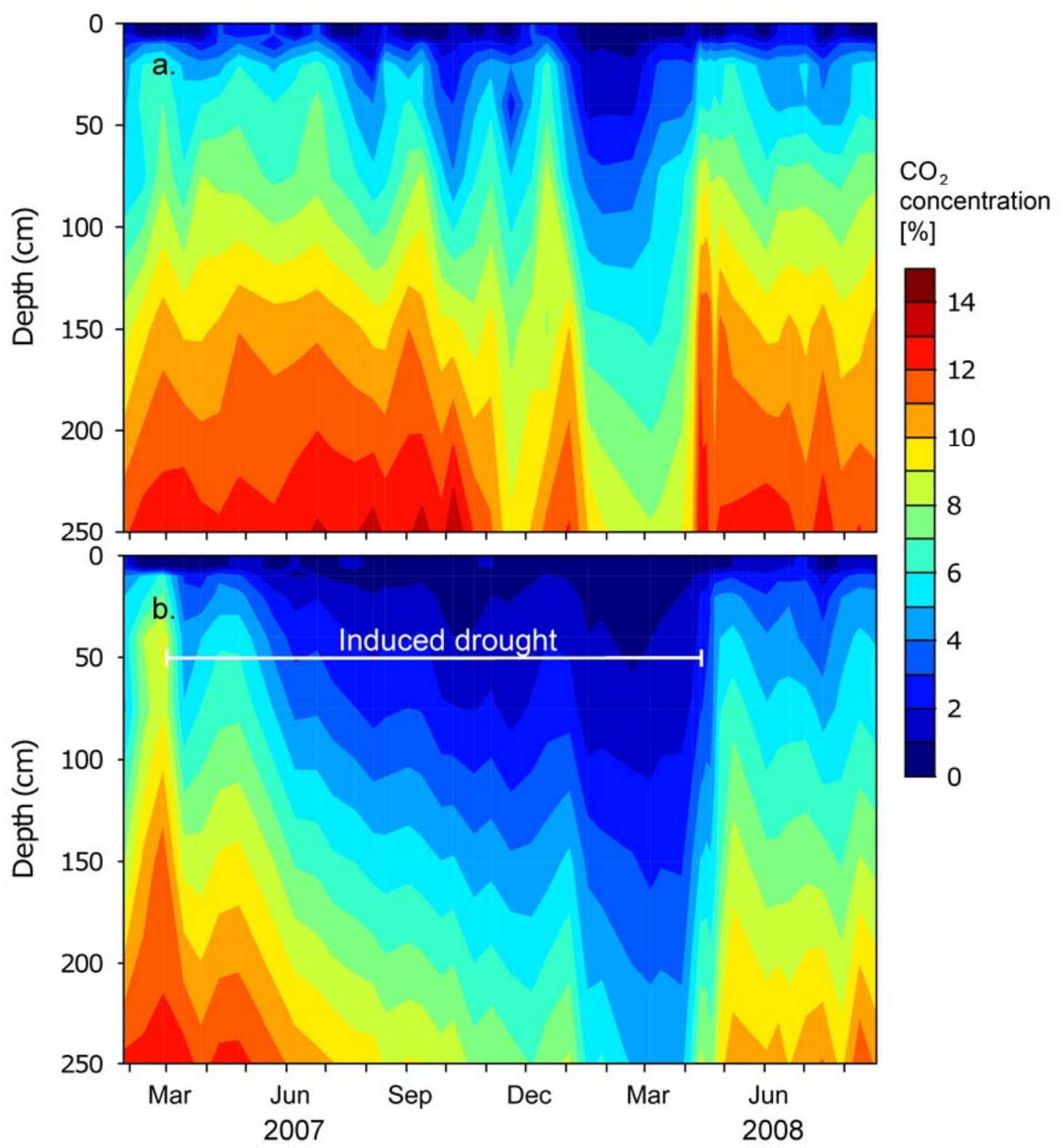

Figure 6: Isopleths of average soil $\mathrm{CO}_{2}$ concentrations (\%) in the soil profile of (a) control plots and (b) roof plots in soil air throughout the experiment period. 


\section{6 $\mathrm{CO}_{2}$ leaching losses}

The control plots on average stored $93 \%$ of the total carbon dioxide in soil water as aqueous $\mathrm{CO}_{2}$, while the remaining $7 \%$ was present in the gaseous phase. In the roof plots, on average $65 \%$ of the total $\mathrm{CO}_{2}$ was dissolved in soil water.

Dissolved $\mathrm{CO}_{2}$ drainage losses during the experiment period are shown in Fig. 1b. In the control plots $\mathrm{CO}_{2}$ leaching losses spiked during periods of high drainage. They reached as high as $36.5 \mathrm{mg} \mathrm{C} \mathrm{m}^{-2} \mathrm{~h}^{-1}$ (15\% of the total $\mathrm{CO}_{2}$ flux), on a single day. However, on average the $\mathrm{CO}_{2}$ drainage in the control plots remained low at $3.5 \mathrm{mg} \mathrm{C} \mathrm{m}^{-2} \mathrm{~h}^{-1}$, which is $2.6 \%$ of the overall surface flux. In the roof plots, $\mathrm{CO}_{2}$ leaching was even lower given the drier soil profile and reduced drainage discharge. During the treatment period soil water drainage approached zero. In these plots the $\mathrm{CO}_{2}$ leaching losses were on average $0.82 \mathrm{mg} \mathrm{C} \mathrm{m}^{-2} \mathrm{~h}^{-1}$.

\section{Discussions}

\section{1 $\mathrm{CO}_{2}$ fluxes in a cacao agroforestry system}

As far as we are aware this study represents the first in situ measurements of soil $\mathrm{CO}_{2}$ dynamics of a cacao agroforestry ecosystem. Measured $\mathrm{CO}_{2}$ efflux rates indicate that the ecosystem is very productive as respiration rates were within or slightly below the range measured in tropical forest ecosystems in Asia (Adachi et al., 2006, Ohashi et al., 2008), and in Latin America (Davidson et al., 2008, Davidson et al., 2000, Schwendenmann et al., 2003, Sotta et al., 2006).

Prior to roof closure, three pre-treatment one-day field campaigns showed no difference in the average soil respiration rates between the control and roof plots. Roof plot respiration averages were slightly higher than the control and are attributed to the higher bulk densities in the control plots.

The main controlling variable driving soil $\mathrm{CO}_{2}$ efflux in this ecosystem was soil moisture. Soil respiration peaked at intermediate soil water contents and declined under both wetter and drier conditions (Fig. 4). Unlike the gradual decline observed in soil respiration when conditions got drier (as was observed in the roof plots and will be discussed later), soil respiration rates in the control plots often plummeted when moist soil became slightly wetter. This is evident by the steep slope shown at wet end of the moisture spectrum. As a result, the $\mathrm{CO}_{2}$ flux in the control plots exhibited strong efflux fluctuations 
with minor changes in soil moisture. The reduction in soil $\mathrm{CO}_{2}$ efflux under the saturated conditions may be a result of a diffusion block that prevented $\mathrm{CO}_{2}$ from exiting the soil through the saturated pore space, and / or prevented oxygen from diffusing into the soil subsequently creating anaerobic conditions (Luo and Zhou, 2006).

$\mathrm{CO}_{2}$ production from the leaf litter was sensitive to moisture conditions. When external conditions were wet, the litter layer could contributed as much as $40 \%$ of the total $\mathrm{CO}_{2}$ efflux, however when conditions were dry, the $\mathrm{CO}_{2}$ contributions from the litter layer was nearly zero percent.

Soil temperature displayed a slightly positive relationship with soil $\mathrm{CO}_{2}$ efflux (data not shown). The temperature influence was however not very predominant given the small temperature variation (in total $3^{\circ} \mathrm{C}$ ) experienced during the 19 month experimental period. In contrast to studies conducted in rainforests in the Amazon basin (Wofsy et al., 1988) and in Costa Rica (Schwendenmann et al., 2003) the influence of solar radiation on plant photosynthesis was not measured in our soil respiration measurements for this site.

Dissolved $\mathrm{CO}_{2}$ leaching beyond $250 \mathrm{~cm}$ soil depth proved to be only a minor $\mathrm{CO}_{2}$ exit flux (Fig. 1b). Considering the high proportion of $\mathrm{CO}_{2}$ stored in the liquid phase, the overall $\mathrm{CO}_{2}$ leaching flux from below $250 \mathrm{~cm}$ was relatively low $\left(3.5\right.$ and $0.8 \mathrm{mg} \mathrm{C} \mathrm{m}^{-2} \mathrm{~h}^{-1}$ for control and roof plots respectively). This is in line or slightly higher than $\mathrm{CO}_{2}$ leaching fluxes reported by Schwendenmann and Veldkamp (2006) and Johnson et al. (2008). The diffusion of carbon dioxide through soil water along the $\mathrm{CO}_{2}$ concentration gradient is considered negligible since liquid phase diffusion (in free water) is more than 8,000 times slower than $\mathrm{CO}_{2}$ transport through free air (Moldrup et al., 2000).

\subsection{Drought effects on soil $\mathrm{CO}_{2}$ efflux}

In contrast to our initial hypotheses, the cacao agroforestry system did not exhibit a strong $\mathrm{CO}_{2}$ efflux response to the induced drought. Instead, the average $\mathrm{CO}_{2}$ efflux declined moderately (13\%) in the roof plots in comparison to the adjacent control plots during the simulated drought. The overall muted $\mathrm{CO}_{2}$ efflux response may be attributed to a number of reasons:

The nature in which $\mathrm{CO}_{2}$ efflux responds to soil moisture may have obscured effect differences between control and roof plots. As has been observed in earlier studies (Davidson et al., 2000, Schwendenmann et al., 2003, Sotta et al., 2006), a pronounced peak of soil $\mathrm{CO}_{2}$ emission was measured at intermediate soil water contents and declined 
under both drier and wetter conditions (Fig. 4). Therefore, when we compare average soil respiration rates between roof plots and control plots during a time when the roof plots were dry and when the control plots were saturated, not only would the measured respiration rates in the roof plots be depressed because of the induced drought, but respiration rates in control plots would also be lower because of the high soil water content.

We have several indirect indications that different $\mathrm{CO}_{2}$ sources reacted differently to drought stress. The first indirect indication comes from the spatial variability of soil respiration across the project area. While eleven efflux chamber sites in the roof plots showed relatively strong declines in soil $\mathrm{CO}_{2}$ efflux as the soil dried out, the other seven efflux chambers, often just a few meters away, exhibited little to no reaction (Fig. 2 and Fig. 3). This localized drought response is indicative of the contrasting processes taking place directly below the respective chambers. The second indirect indication was that soil $\mathrm{CO}_{2}$ efflux from chambers that exhibited strong drought response correlated closely to the sap flux ratios of both cacao $(\mathrm{R}=0.61, \mathrm{P}<0.01)$ and Gliricidia trees $(\mathrm{R}=0.65, \mathrm{P}=0.01)$ as reported by Schwendenmann et al. (2010). In contrast, those chambers that did not exhibit a drought sensitive $\mathrm{CO}_{2}$ efflux did not correlate significantly with sap flux density. Although this does not necessarily establish a causal relationship between soil $\mathrm{CO}_{2}$ efflux and tree sap flux, it does however show that when tree metabolisms slowed down, we correspondingly measured lower $\mathrm{CO}_{2}$ effluxes from the drought responsive efflux chambers. Our interpretation is that these drought responsive chambers, which had higher than average respiration rates even during the pre-treatment measurements, were situated above active roots and the onset of drought conditions induced tree drought stress which resulted in root respiration decreases. This is substantiated by the strong correlation between the average soil respiration prior to roof closure (pre-treatment) and the drought response index $\left(\mathrm{R}^{2}=0.76, \mathrm{P}<0.01, \mathrm{n}=18\right)$. This means that the high flux chambers were situated above already active $\mathrm{CO}_{2}$ production sources, very likely active roots, which were susceptible to drought stress.

Furthermore, the drought effect on autotrophic respiration was again detected when examining the relationship between soil $\mathrm{CO}_{2}$ efflux and the distance to tree stems. We found that the drought response index declined with distance from cacao tree stems suggesting that cacao rooting activity near the stem declined during the induced drought while further away the effect was not as pronounced. We also found that average soil $\mathrm{CO}_{2}$ respiration rates declined with distance from cacao tree stems in both control and roof 
plots. Soil compaction was excluded as a potential explanatory variable for these decreases, as bulk density cores taken at $0.25 \mathrm{~m}$ distance intervals outward from the tree stem to a maximum distance of $1.75 \mathrm{~m}$, failed to show any systematic increases with distance ( $n=6$ cacao trees). Stem flow and the potentially wetter conditions around the tree base was also excluded as an explanatory variable as we did not find an evident relationship between the average soil moisture and the respective distance to the tree.

Unlike the cacao trees, we did not observe similar tree distance relationships with Gliricidia trees. This is thought to be primarily due to the deeper and more diffuse root architecture and rooting behaviour exhibited by Gliricidia fine roots (Moser et al., 2010), which may have masked measurable effects with distance. A Deuterium $(\delta \mathrm{D})$ study by Schwendenmann et al. (2010) found that tree water uptake was partitioned vertically in the soil horizon, where cacao accessed water from the upper horizons while Gliricidia explored for water in deeper soil layers.

Additionally, a root excavation exercise done by Moser et al. (2010) at the site, found that coarse roots of both cacao and Gliricidia were primarily concentrated around the tree stems while fine root (diameter $<2 \mathrm{~mm}$ ) distributions extended well into the agroforestry plantation. Other studies by Harteveld et al. (2008) and Kummerow et al. (1982) confirm that cacao fine roots extend well beyond the stem and are primarily concentrated in the uppermost $30 \mathrm{~cm}$. Although overall autotrophic respiration rates appeared to decline, Moser et al. (2010) reported that cacao and Gliricidia fine root biomass remained unchanged at all soil depths to $250 \mathrm{~cm}$, over the duration of the 13-month induced drought. These findings suggest that regardless of the drought stress, the trees still continued to maintain and build new fine roots required to search for available water resources.

The litter layer, as was previously mentioned, is sensitive to changes in moisture regimes. Therefore, given that the litter layer would have dried out relatively quickly, the effect on soil respiration would have also been correspondingly fast. By the end of the roof experiment, in April 2008, considerable amounts of leaf litter had accumulated on the ground of the roof plots, although leaf litter fall was unaffected by the induced drought (Schwendenmann et al., 2010). This is an additional indication that decomposition rates decreased under the drier conditions.

Although we have little data to substantiate how heterotrophic $\mathrm{CO}_{2}$ respiration from soil microorganisms in the bulk soil reacted to the drought, the results from the leaf litter study clearly show that heterotrophic respiration was sensitive to droughts. 


\subsection{Belowground $\mathrm{CO}_{2}$ dynamics}

Baseline carbon dioxide concentrations in deep soil air were among the highest ever reported for soils. The average $\mathrm{CO}_{2}$ concentration at $250 \mathrm{~cm}$ soil depth in the control plots was $11.8 \%$, and peaked at $15.3 \%$, during the 19 -month experiment. As far as we are aware of no other study has found $\mathrm{CO}_{2}$ concentrations of this magnitude so close to the soil surface. The $\delta \mathrm{C}^{13}$ isotope signature $\left(-23.63 \%\right.$ ) confirmed that the $\mathrm{CO}_{2}$ was produced by biological sources and most likely originated from plants having a $\mathrm{C}_{3}$ photosynthetic pathway - such as cacao or Gliricidia.

The high $\mathrm{CO}_{2}$ concentrations in soils of the cacao agroforestry ecosystem are thought to be caused by a diffusion block that prevented $\mathrm{CO}_{2}$ molecules from travelling upward along the concentration gradient to the atmosphere. Gaseous $\mathrm{CO}_{2}$ diffusion was slowed down by the soil medium's high bulk density (low porosity), high concentration of coarse rock fragments as well as soil water. Each of these components would have increased the tortuousness of the gas pathway to the soil surface. During wet conditions $\mathrm{CO}_{2}$ concentrations were high in the soil air, as the pore-space would have been saturated with water and resulted in slow diffusion. However, as soon as the soil dried out the $\mathrm{CO}_{2}$ concentrations began to decline, as there were more open air filled pore-spaces available for $\mathrm{CO}_{2}$ diffusion. This trend is apparent in both the roof plots (where we artificially manipulated the soil moisture) and in the control plots during a natural drought in January - February 2008 (Fig. 6). In and of itself, the soil air $\mathrm{CO}_{2}$ concentrations do not say very much about the soil carbon allocation dynamics, but highlight the $\mathrm{CO}_{2}$ storage capacity of the soil.

Attempts to determine $\mathrm{CO}_{2}$ production shifts with time vertically within the soil profile by modelling $\mathrm{CO}_{2}$ production from soil air $\mathrm{CO}_{2}$ concentrations with a one dimensional gas transport model were not successful. We believe that due to the high rock fragment content and the heterogeneous composition of the sub-soil various assumptions required by the gas transport model were not met.

\subsection{Rewetting phases}

In November 2007, approximately halfway through the simulated drought period, soil respiration rates in the roof plots (at both drought responsive and non-responsive chamber sites) experienced a short lived rebound that lasted for approximately two months. The rebound coincided with two small rewetting peaks measured in the uppermost $40 \mathrm{~cm}$ of the 
soil, during an extended period of intense rain showers. During this time it is speculated that the $\mathrm{CO}_{2}$ flush resulted from a sudden burst in root activity and a pulse of microbial activity which mineralized built up organic compounds.

The second and planned rewetting phase took place after the first rain showers following the roof opening in April 2008, at which time we measured a flush of $\mathrm{CO}_{2}$ from the soil surface that lasted for approximately two weeks. During this time the labile carbon stocks that had accumulated during the induced drought (including dead roots, accumulated litter and other organic compounds) probably mineralized. Additionally, tree roots may have responded to the favourable soil moisture conditions and at minimum resumed normal activity, or extended their root network. Schwendenmann et al. (2010) reported that sap flux densities of both cacao and Gliricidia trees recovered quickly.

Beyond the initial two week flush, average soil $\mathrm{CO}_{2}$ fluxes remained slightly but not significantly above control plot averages until the end of the measurement period in late August 2008. This is likely due to two reasons: 1) the time the ecosystem required to return to equilibrium - for trees to extend their root systems and for microorganisms to decompose built up carbon stocks, or 2) it may reflect the effect of slightly higher bulk densities in the control plots.

\section{Conclusions}

Although, there were evidently some carbon reallocation responses to drought periods in the cacao agroforestry ecosystem, the net effect on soil $\mathrm{CO}_{2}$ production and emission over the duration of the experiment was neutral. During the 13-month treatment phase, we observed slight decreases in soil respiration in the roof plots likely due to localized changes in root activity, and declines in decomposition rates both above and belowground. The decline in soil respiration in the treatment period were however compensated for during the post-treatment phase (after roof opening), when accumulated labile carbon stocks, both above and below ground mineralized, and when trees recovered from their drought stress. 


\section{CHAPTER 3}

EFFECTS OF A SIMUlated DROUGHT ON SOIL $\mathrm{CO}_{2}$ PRODUCTION IN A SUB-MONTANE TROPICAL FOREST IN CENTRAL SULAWESI, INDONESIA

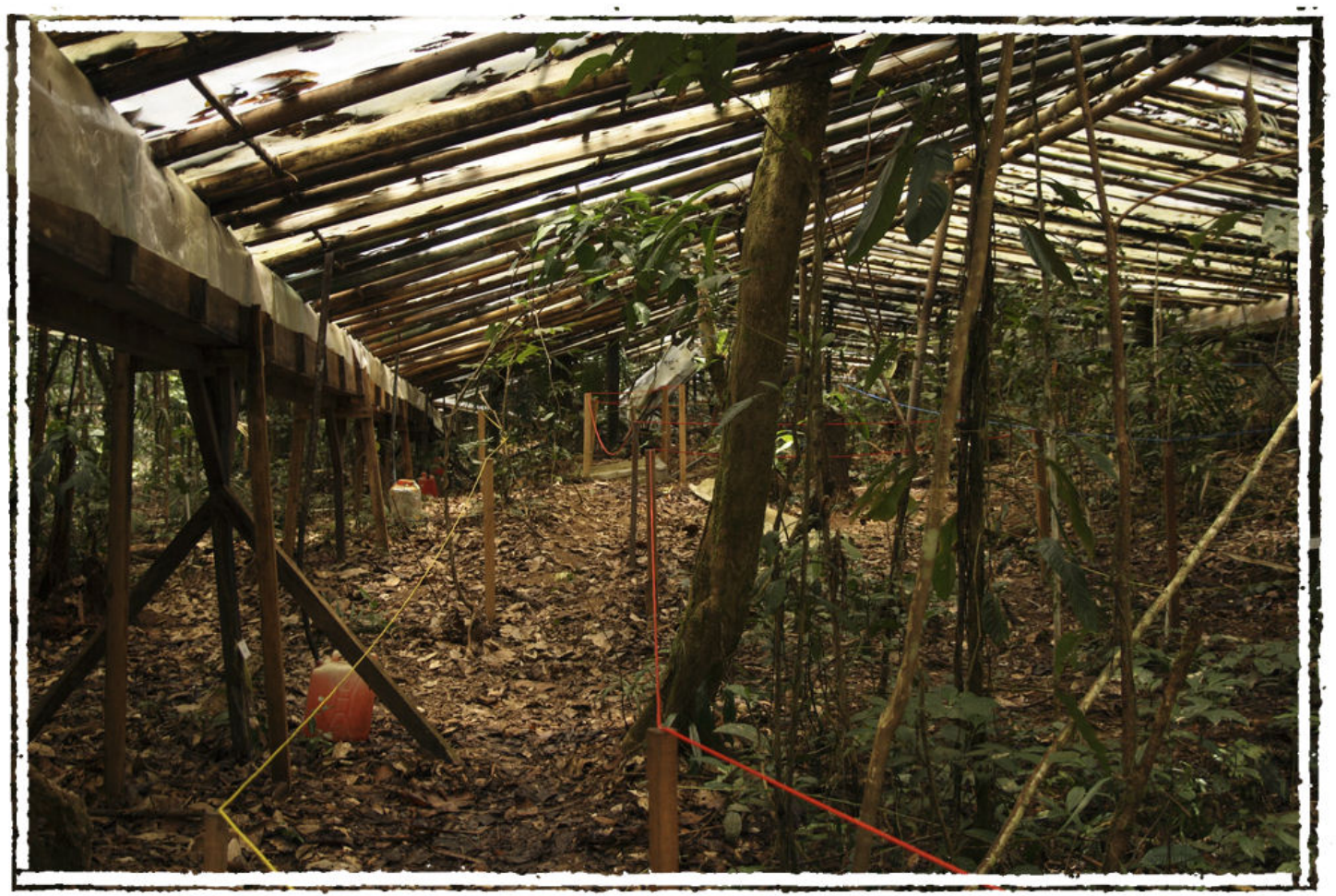

A REVISED VERSION HAS BEEN SUBMITTED TO GLOBAL CHANGE BIOLOGY 


\title{
EFFECTS OF A SIMULATED DROUGHT ON SOIL $\mathrm{CO}_{2}$ PRODUCTION IN A SUB- MONTANE TROPICAL FOREST IN CENTRAL SULAWESI, INDONESIA
}

\author{
Oliver van Straaten ${ }^{1}$, Edzo Veldkamp ${ }^{1}$, Marife D. Corre ${ }^{1}$ \\ 1 Buesgen-Institute, Soil Science of Tropical and Subtropical Ecosystems, Georg-August-University of \\ Goettingen, Buesgenweg 2, 37077 Goettingen, Germany
}

\begin{abstract}
Drought response on soil $\mathrm{CO}_{2}$ production dynamics was examined in a sub-montane tropical rainforest (1050 m.a.s.1.) in central Sulawesi, Indonesia. A large-scale throughfall displacement roof was built in the ecosystem understory to simulate drought conditions. During the 31 month experiment, soil $\mathrm{CO}_{2}$ production was measured biweekly both vertically within the soil profile to $2.5 \mathrm{~m}$ depth by using a one dimensional gas diffusion model and also spatially across the plot area by measuring surface $\mathrm{CO}_{2}$ efflux at permanently embedded chambers distributed throughout the project area. We additionally partitioned $\mathrm{CO}_{2}$ production into leaf litter, belowground heterotrophic (microbial) and autotrophic (root) respiration sources. During the 24.5 month induced drought the sub-montane tropical rainforest experienced a severe decrease in soil $\mathrm{CO}_{2}$ production. Soil $\mathrm{CO}_{2}$ efflux decreased by an average of $39 \%$ in comparison to the control during induced drought period. Soil moisture, the main variable controlling $\mathrm{CO}_{2}$, exhibited a strong positive linear relationship with soil $\mathrm{CO}_{2}$ production $\left(\mathrm{R}^{2}=0.72\right)$. A two phase ecosystem drought response was observed. During the first phase, which lasted nine months, leaf litter respiration declined as did the $\mathrm{CO}_{2}$ production between 30 and $70 \mathrm{~cm}$ soil depth. During the second phase of the experiment (the next 16 months) drought conditions intensified further and belowground $\mathrm{CO}_{2}$ production from heterotrophic and autotrophic sources decreased at all soil depths. Leaf litter respiration remained negligible. Recuperation after the drought was slow and did not rebound to control plot levels. Although overall soil $\mathrm{CO}_{2}$ emission decreased in the roof plots in comparison to the control during the experiment, the full extent of drought impact on $\mathrm{CO}_{2}$ emissions may require years to determine as accumulated coarse woody debris that died as a result of drought stress needs time to decompose.
\end{abstract}

Keywords: Indonesia, ENSO, drought, soil respiration, carbon dioxide production, soil moisture 


\section{Introduction}

The tropical forest ecosystems of Southeast Asia are currently under threat of climate change. Some climate models predict that droughts related to the El Niño Southern Oscillation (ENSO) phenomenon will increase in frequency and intensity in Indonesia and region (Sheffield and Wood, 2008, Timmermann et al., 1999). Changes in precipitation regimes can alter both aboveground and belowground carbon stock allocations (Davidson et al., 2004). Since tropical forest soils store one third of the global soil carbon within the top meter of soil (Jobbágy and Jackson, 2000) and much of the stored carbon has a short residence time (Amundson, 2001) changes in precipitation regimes can have rapid impact on stored carbon stocks (Trumbore et al., 1995). Understanding how belowground carbon dynamics react to a changing climate is of fundamental importance to better predict the strength and direction of carbon fluxes to and from the atmosphere.

Ecosystem drought response is largely dependent on the mechanisms available to adapt to drought and the site specific soil water retention characteristics (Davidson et al., 2008, Sotta et al., 2007). The presence or absence of deep roots is one of the adaptation mechanisms used to mitigate drought effects (Nepstad et al., 1994). There are indications that ecosystems that experience regular but strong dry seasons, such as the forests in the eastern Amazon, have adapted and developed deeper root systems to access water resources deeper in the soil profile (Nepstad et al., 1994). In contrast, ecosystems that receive a high amount of rainfall and do not experience regular extended dry seasons, such as forests in Indonesia, typically have shallower root systems (Schenk and Jackson, 2002) which may therefore render them more vulnerable to droughts.

While there has already been extensive research done on drought effects in the tropical forests of Latin America (Brando et al., 2008, Fisher et al., 2007, Nepstad et al., 2002c, Phillips et al., 2009), relatively little emphasis has focused on drought vulnerabilities of tropical forests in Southeast Asia. To evaluate the drought susceptibility of Indonesia's tropical forests we established a large-scale throughfall manipulation experiment on an upland forest site on the island of Sulawesi. In this paper we report on soil carbon dioxide production dynamics measured spatially across the experiment plots, vertically within the soil profile to 2.5 meters depth. We also partitioned $\mathrm{CO}_{2}$ production into leaf litter, belowground heterotrophic (microbial), and autotrophic (root) respiration sources. The objectives of this study were two-fold:

1. To identify how different $\mathrm{CO}_{2}$ production sources react to drought and subsequent rewetting. 
2. To identify the temporal and spatial controls regulating soil $\mathrm{CO}_{2}$ production.

Our expectations were that this sub-montane tropical forest ecosystem will be drought sensitive. This ecosystem has rarely, if ever, experienced extended dry periods and accordingly has not adapted mechanisms to deal with drought. We hypothesize that the ecosystem would exhibit a progressive decrease in soil respiration as different $\mathrm{CO}_{2}$ production sources begin to exhibit drought stress. The ecosystem recovery would depend highly on the severity of the drought and whether plants die due to drought stress.

\section{Materials and Methods}

\subsection{Site description}

The simulated drought experiment was carried out in a old-growth pre-montane tropical forest on the eastern edge of the Lore Lindu National Park in central Sulawesi, Indonesia $\left(1.494^{\circ} \mathrm{S}, 120.057^{\circ} \mathrm{E}\right)$ at 1,050 meters above sea level (m.a.s.l.). The plots were established in the remote Pono Valley, a two hour walk from the village of Toro on a geomorphological terrace in an otherwise rugged and steep landscape. This site was selected because of its undisturbed condition, its well drained soils, the deep water table ( $>4 \mathrm{~m}$ ) and a mild slope $\left(0-20^{\circ}\right)$, which provided good conditions for the building of the throughfall displacement roof. The forest has a high tree species diversity with about 130 species $\mathrm{ha}^{-1}$, an average tree stem density of 456 stems per hectare $(>10 \mathrm{~cm} \mathrm{DBH})$ and a canopy height of about $45 \mathrm{~m}$ (Culmsee and Pitopang, 2009).

The site's heavily weathered soil have been classified as a Ferralsol (World Reference Base for Soil Resources, Leitner and Michalzik, unpublished data), having a clay-loam texture dominated by kaolinite clay and hematite. The topsoil (top $40 \mathrm{~cm}$ ) was acidic with a $\mathrm{pH}$ of $4.5\left(\mathrm{pH}\left(\mathrm{H}_{2} \mathrm{O}\right)\right.$, it had a low bulk density $0.9 \mathrm{~g} \mathrm{~cm}^{-3}$, and a $\mathrm{C}: \mathrm{N}$ ratio of 13.3. Soil chemical and physical properties for the control and roof plot soil profiles are summarized in Table 1. Organic matter decomposition rates were rapid as was evident by the thin organic layer mat (on average $3.8 \mathrm{~cm}$ thick). The majority of both fine and course roots were concentrated within the top $20 \mathrm{~cm}$ of soil (74\% and $91 \%$ respectively)(Hertel et al., 2009).

Precipitation at the site, measured at a climate tower installed onsite, was 2,901 mm yr in 2008. The mean air temperature was $20.6^{\circ} \mathrm{C}$. No clear seasonal pattern in either 
precipitation or air temperature was observed during the 2.5 year weather record (March 2007 - October 2009).

Table 1: Soil physical and chemical properties: bulk density, soil texture, carbon and nitrogen content, effective cation exchange capacity (ECEC) and $\mathrm{pH}\left(\mathrm{H}_{2} \mathrm{O}\right)$ of the $250 \mathrm{~cm}$ soil profile. The values are means \pm 1 SE. For all variables $n=3$, except bulk density $n=6$.

\begin{tabular}{|c|c|c|c|c|c|c|c|c|}
\hline Depth & $\begin{array}{l}\text { Bulk density } \\
\left(\mathrm{g} \mathrm{cm}^{-3}\right)\end{array}$ & Sand (\%) & $\begin{array}{l}\text { Soil texture } \\
\text { Silt (\%) }\end{array}$ & Clay (\%) & $\begin{array}{l}\text { Carbon } \\
\left(\mathrm{g} \mathrm{kg}^{-1}\right)\end{array}$ & $\begin{array}{l}\text { Nitrogen } \\
\left(\mathrm{g} \mathrm{kg}^{-1}\right) \\
\end{array}$ & $\begin{array}{c}\text { ECEC } \\
\left(\mathrm{cmol} \mathrm{kg}^{-1}\right) \\
\end{array}$ & $\begin{array}{l}\text { Soil pH } \\
\left(\mathrm{H}_{2} \mathrm{O}\right)\end{array}$ \\
\hline \multicolumn{9}{|c|}{ Control Plots } \\
\hline-5 & $0.73 \pm 0.05$ & $32.3 \pm 2.1$ & $30.3 \pm 2.3$ & $37.6 \pm 2.7$ & $34.1 \pm 7.0$ & $2.8 \pm 0.5$ & $7.2 \pm 0.4$ & $4.3 \pm 0.1$ \\
\hline-10 & $0.86 \pm 0.04$ & $27.7 \pm 2.7$ & $31.9 \pm 3.9$ & $40.4 \pm 6.1$ & $28.7 \pm 4.4$ & $2.1 \pm 0.3$ & $5.7 \pm 0.3$ & $4.3 \pm 0.0$ \\
\hline-20 & $0.92 \pm 0.04$ & $27.8 \pm 2.2$ & $29.6 \pm 4.2$ & $42.6 \pm 5.0$ & $15.2 \pm 1.8$ & $1.1 \pm 0.1$ & $4.9 \pm 0.2$ & $4.7 \pm 0.1$ \\
\hline-40 & $1.08 \pm 0.07$ & $28.7 \pm 2.7$ & $34.5 \pm 5.7$ & $36.8 \pm 4.7$ & $13.9 \pm 1.3$ & $1.0 \pm 0.1$ & $4.5 \pm 0.4$ & $4.6 \pm 0.1$ \\
\hline-75 & $1.32 \pm 0.02$ & $31.8 \pm 1.4$ & $39.9 \pm 4.4$ & $28.2 \pm 5.8$ & $6.4 \pm 0.3$ & $0.4 \pm 0.0$ & $5.4 \pm 0.7$ & $4.7 \pm 0.1$ \\
\hline-150 & $1.34 \pm 0.03$ & $36.1 \pm 1.5$ & $49.6 \pm 1.3$ & $14.3 \pm 1.7$ & $3.5 \pm 0.3$ & $0.2 \pm 0.0$ & $6.0 \pm 0.7$ & $5.0 \pm 0.1$ \\
\hline-250 & $1.27 \pm 0.08$ & $36.5 \pm 5.9$ & $52.6 \pm 9.0$ & $10.9 \pm 3.1$ & $3.2 \pm 0.5$ & $0.2 \pm 0.0$ & $5.8 \pm 1.2$ & $5.2 \pm 0.0$ \\
\hline \multicolumn{9}{|c|}{ Roof Plots } \\
\hline-5 & $0.70 \pm 0.03$ & $26.3 \pm 2.9$ & $36.1 \pm 2.4$ & $37.6 \pm 1.6$ & $29.1 \pm 3.0$ & $2.4 \pm 0.2$ & $7.0 \pm 0.4$ & $4.4 \pm 0.3$ \\
\hline-10 & $0.81 \pm 0.02$ & $24.6 \pm 2.6$ & $35.9 \pm 1.6$ & $39.5 \pm 1.6$ & $25.6 \pm 1.8$ & $1.9 \pm 0.1$ & $5.5 \pm 0.0$ & $4.4 \pm 0.0$ \\
\hline-20 & $0.92 \pm 0.03$ & $24.7 \pm 2.4$ & $38.9 \pm 4.5$ & $36.4 \pm 2.9$ & $18.8 \pm 2.0$ & $1.3 \pm 0.2$ & $5.2 \pm 0.5$ & $4.7 \pm 0.2$ \\
\hline-40 & $1.13 \pm 0.01$ & $26.1 \pm 1.8$ & $38.7 \pm 3.6$ & $35.3 \pm 4.0$ & $10.8 \pm 0.3$ & $0.7 \pm 0.0$ & $5.3 \pm 0.2$ & $4.6 \pm 0.1$ \\
\hline-75 & $1.30 \pm 0.02$ & $31.7 \pm 2.8$ & $37.9 \pm 1.7$ & $30.4 \pm 4.4$ & $6.7 \pm 1.0$ & $0.4 \pm 0.1$ & $5.6 \pm 0.3$ & $5.2 \pm 0.1$ \\
\hline-150 & $1.28 \pm 0.02$ & $33.7 \pm 6.6$ & $42.4 \pm 5.7$ & $23.9 \pm 5.5$ & $4.0 \pm 0.4$ & $0.2 \pm 0.0$ & $5.2 \pm 0.9$ & $5.1 \pm 0.1$ \\
\hline-250 & $1.25 \pm 0.06$ & $31.6 \pm 8.2$ & $52.0 \pm 9.9$ & $16.5 \pm 2.2$ & $3.0 \pm 0.5$ & $0.2 \pm 0.0$ & $6.0 \pm 0.2$ & $5.2 \pm 0.1$ \\
\hline
\end{tabular}

\subsection{Experimental design}

We established the experiment in a stratified random design using six plots, each $40 \times 40 \mathrm{~m}$ in size, spread out over an area of approximately five hectares. While three plots were left undisturbed (control), three treatment plots, hereafter called "roof plots", were used to simulate drought conditions. In the simulated drought plots we built a transparent roof below the plantation canopy to divert throughfall away from the plot. The roof consisted of transparent polyethylene plastic sheets mounted on several thousand individual bamboo frames $(0.5 \times 5 \mathrm{~m})$ at an average height of $1.7 \mathrm{~m}$ above the ground. The roof was initially $\pm 70 \%$ closed, and only small gaps remained around the tree stems and between some panels. In early 2008, the roof closure was further increased to approximately $\pm 90 \%$ by building custom sized panels to close gaps around tree stems and odd sized openings. Runoff was diverted into a series of wooden, plastic lined gutters and channelled down-slope away from the plots. Every two weeks the leaf litter that accumulated on the roof panels was transferred back to the soil surface. Temperature, humidity and incident radiation under the panels were unaffected by the establishment of 
the roof. Along the perimeter of each plot a $0.4 \mathrm{~m}$ trench was dug and lined with plastic so as to prevent lateral and surface water flows from entering the plots.

All measurements were made within a 'core zone' $(30 \times 30 \mathrm{~m})$ in the plot, leaving a $5 \mathrm{~m}$ buffer zone along the inside of the plot boundary to avoid edge effects. Per plot one central soil pit $(0.8 \mathrm{~m}$ width $\times 1.6 \mathrm{~m}$ length $\times 3.0 \mathrm{~m}$ depth $)$ was dug and equipped with gas samplers, thermocouples and soil moisture probes. Three transects per plot were set up within the 'core zone' for soil $\mathrm{CO}_{2}$ flux measurements.

Carbon dioxide respiration measurements began in early February, 2007, two and a half months prior to the roof closure in the treatment plots. These pre-treatment measurements were made to verify that control and roof plots did not exhibit any initial systematic differences. The roof was closed at the beginning of May 2007 and remained closed for 24.5 months. The roof was opened in mid May, 2009 and measurements continued for an additional four months to monitor the recovery of the ecosystem.

\subsection{Measurements of soil surface $\mathrm{CO}_{2}$ efflux}

Soil surface $\mathrm{CO}_{2}$ efflux from soil respiration was measured using the dynamic closed chamber method described by Parkinson (1981). Soil $\mathrm{CO}_{2}$ efflux was measured every two weeks during the 31 month simulated drought experiment using a portable infrared $\mathrm{CO}_{2}$ gas analyzer (IRGA) mounted on a backpack frame. In total, 68 field visits were made. Two measurement campaigns (field visits) were missed in August 2007 due to an equipment failure with the gas analyzer (IRGA). During each field visit $\mathrm{CO}_{2}$ efflux was measured at 36 chamber sites spread out over the six plots. The round chamber bases (0.045 $\mathrm{m}^{2}$ area, $0.15 \mathrm{~m}$ height) made from polyvinyl chloride (PVC) were deployed in each plot in three randomly situated transects (two chamber bases per transect). A detailed explanation of the $\mathrm{CO}_{2}$ efflux measurements and the IRGA calibration is described in van Straaten et al.(2010).

Two additional experiments were carried out to partition soil $\mathrm{CO}_{2}$ production sources into three components: 1) leaf litter respiration 2) autotrophic (root) respiration in the top $30 \mathrm{~cm}$ and 3) belowground heterotrophic (microorganism) respiration. In the litter contribution experiment, we randomly selected six experiment chambers (from the drought experiment) in the control plot and installed two additional chambers directly adjacent to these 'main' chambers ( $<1 \mathrm{~m}$ away). We transferred litter from one chamber into the second chamber. The 'main' chamber was left undisturbed and used as a control. Leaf litter respiration $\left(\mathrm{R}_{\mathrm{L}}\right)$ was calculated by subtracting the soil $\mathrm{CO}_{2}$ efflux respired by the empty 
chamber with no leaf litter from the control chamber. Measurements were conducted during 62 of the 68 field visits made for the drought experiment measurements. Six measurements were missed because of inclement weather conditions.

The partition between autotrophic $\left(\mathrm{R}_{\mathrm{A}}\right)$ root respiration and belowground heterotrophic respiration $\left(\mathrm{R}_{\mathrm{H}}\right)$ was determined using a root trenching technique similar to the method described by Wang and Yang (2007). In each plot, two drought experiment chamber locations were randomly selected. Next to the 'main' chamber we installed an additional second chamber, around which a $30 \mathrm{~cm}$ deep trench was dug, approximately $15 \mathrm{~cm}$ from the outside of the chamber base. This is hereafter referred to as a "trenched" chamber. The excavation cut incoming roots and with it the supply of photosynthates from plants. The trench was double lined with a heavy duty plastic and backfilled with the original soil. In total, twelve chamber pairs were installed (six in the control and six in the roof plots) in late November 2008. Prior to making the first measurements we waited for a period of four weeks to allow soil respiration to equilibrate and the dead roots some time to decompose. Soil $\mathrm{CO}_{2}$ efflux measurements from the chamber pairs (trenched and untrenched) were made within a period of ten minutes of another. Respiration rates were subsequently compared. The $\mathrm{CO}_{2}$ respired from the trenched chambers theoretically constituted the "heterotrophic" component. The belowground heterotrophic respiration component was calculated by subtracting the $\mathrm{CO}_{2}$ produced by the litter layer (as determined from the leaf litter - soil moisture relationship) from total heterotrophic respiration. Root respiration was calculated as the difference between the trenched and the un-trenched chambers.

It should be recognized however, that the trenching approach has a few known shortcomings. The heterotrophic (microbial) respiration may be overestimated because roots are still active below the trenching zone and will therefore contribute to the $\mathrm{CO}_{2}$ flux measured in the trenched chamber. However, this error is regarded as small considering that the majority of roots are located in the top $30 \mathrm{~cm}(80 \%$ of the fine roots and $95 \%$ of the coarse roots). Secondly, the cut roots during the trenching will decompose and in doing so will respire $\mathrm{CO}_{2}$, which again overestimates heterotrophic respiration. Lastly, soil moisture conditions would also have been modified in the trenched region since the absence of live roots meant that there was no active water uptake.

The trenching experiment chambers were measured biweekly. In total 20 measurements were carried out between December 21, 2008 and September 9, 2009. 


\subsection{Root biomass}

Following the completion of the infrared $\mathrm{CO}_{2}$ gas analyzer (IRGA) field measurements in September 2009 all the $\mathrm{CO}_{2}$ efflux chambers were excavated to a depth of $10 \mathrm{~cm}$. Roots were separated from the soil, dried and then weighed to determine the root biomass. We separated the roots into three categories: fine roots $(<2 \mathrm{~mm}$ diameter $)$, medium roots (between $2 \mathrm{~mm}$ and $10 \mathrm{~mm}$ diameter) and large roots (>10 $\mathrm{mm}$ diameter).

\subsection{Soil air $\mathrm{CO}_{2}$ concentrations and soil moisture depth profiles}

Gas samples for analyses of $\mathrm{CO}_{2}$ concentrations were collected from one central soil pit per plot. Samples were taken on a bi-weekly basis in tandem with the soil surface respiration measurements. Gas samplers were installed horizontally into the soil profile at different depths in the soil profile $(10,20,40,75,150$ and $250 \mathrm{~cm})$. While the $1 \mathrm{~mm}$ inner diameter gas samplers in the top $75 \mathrm{~cm}$ were $1 \mathrm{~m}$ long, the samplers at $150 \mathrm{~cm}$ and $250 \mathrm{~cm}$ depth were 2 meters in length to avoid errors introduced by horizontal diffusion losses through the pit wall. A detailed description of the gas samplers and the gas sampling technique is described by van Straaten et al .(2010). Soil $\mathrm{CO}_{2}$ concentration samples were taken during 70 field campaigns, in tandem with the IRGA soil respiration measurements.

Gas samples were analyzed in a laboratory at Tadulako University in Palu, Sulawesi, within 72 hours after collection in the field. The $\mathrm{CO}_{2}$ concentration of each sample was measured with a gas chromatograph (GC) (GC-11, Delsi Instruments, Suresnes, France) with a thermal conductivity detector (TCD). Sample $\mathrm{CO}_{2}$ concentrations were calculated by comparing the integrated peak areas to that of two known standard gas concentrations $(0.07 \%$ and $3.5 \%$, Deuste Steininger GmbH, Mühlhausen, Germany), to make a two point calibration.

Additional to the $\mathrm{CO}_{2}$ concentration and temperature measurements, we also measured volumetric soil water content using time domain reflectometry (TDR) sensors (Campbell CS616) in three soil pits per plot. While in the two secondary soil pits TDRs were installed at 10,40 and $75 \mathrm{~cm}$ depths, TDRs in the central soil pit were installed adjacent to each gas sampler at the same respective sampler's depth. The TDR sensors were inserted horizontally into the undisturbed soil at the end of a $30 \mathrm{~cm}$ hole dug into the soil pit wall. Soil moisture was recorded hourly using a datalogger (Campbell CR1000). Using undisturbed soil samples we calibrated the water content measurements using the methodology described by Veldkamp \& O'Brien (2000). TDR measurements began on 
March 27, 2007 in the roof plots and on May 31, 2007 in the control plots. The start of the measurements was delayed resulting from a lightning strike in March 2007 that damaged both dataloggers and TDR sensors. Volumetric water content was subsequently recalculated to water matrix potential using $\mathrm{pF}$ curves measured using pressure plates in the laboratory at the Georg-August-University of Goettingen, Germany (van Genuchten, 1980).

\section{$2.6 \mathrm{CO}_{2}$ production in soil profiles}

The vertical partitioning of $\mathrm{CO}_{2}$ production sources within the soil profile was modeled using the methodology described by de Jong and Schappert (1972). This approach requires five assumptions: 1) gaseous diffusion is the only mechanism of $\mathrm{CO}_{2}$ transport (no convective transport of $\left.\mathrm{CO}_{2}\right), 2$ ) changes in soil air $\mathrm{CO}_{2}$ concentrations over time are very small, i.e. conditions are considered steady state, 3) there are no $\mathrm{CO}_{2}$ sinks within the soil profile 4) horizontal or downward diffusion is considered negligible and 5) soil air pressure is at equilibrium with the soil surface.

Soil $\mathrm{CO}_{2}$ production was determined by calculating the difference between the $\mathrm{CO}_{2}$ flux coming in (from below) and going out (to upper layers above) for each horizontal $(5 \mathrm{~cm})$ layer. The $\mathrm{CO}_{2}$ flux of each layer was determined using Fick's first law of diffusion (Equation 1). It states that the rate of gaseous diffusion is proportional to the concentration gradient in space - in our case, soil depth. The mathematical equation is expressed as follows:

$$
F=-D_{s} \times \frac{\partial C}{\partial z}
$$

where $\mathrm{F}$ is the $\mathrm{CO}_{2}$ flux at any point in the soil profile $\left(\mathrm{mg} \mathrm{C} \mathrm{m}^{-2} \mathrm{~h}^{-1}\right) ; \mathrm{D}_{\mathrm{s}}$ is the gas diffusion coefficient of $\mathrm{CO}_{2}$ in soil $\left(\mathrm{cm}^{2} \mathrm{~s}^{-1}\right)$ and $\partial \mathrm{C} / \partial \mathrm{z}$ is the change in $\mathrm{CO}_{2}$ concentration $(\%)$ with change in soil depth $(\mathrm{cm})$.

The production term of each layer was calculated by adjusting Fick's second law (equation 2), which predicts how diffusion changes the concentration field with time.

$$
\frac{\partial C}{\partial t}=-\frac{\partial F}{\partial z}+S
$$


$\partial C / \partial t$ is the change in $\mathrm{CO}_{2}$ concentration in time $(\mathrm{t}) ; \partial \mathrm{F} / \partial \mathrm{z}$ is the change in $\mathrm{CO}_{2}$ flux with depth; and $\mathrm{S}$ is the sink / source term, i.e. the amount produced in each layer. Based on the steady-state assumption, $\partial C / \partial t$ is equal to zero. The production equation can therefore be rearranged to solve for S. Inserting equation 1 into the rearranged equation 2 we get the following:

$$
S=-\frac{\partial}{\partial z}\left(D_{s} \times \frac{\partial C}{\partial z}\right)
$$

The first step to solve this equation is to calculate the gas diffusion coefficient in soil $\left(D_{s}\right)$. $\mathrm{D}_{\mathrm{s}}$ is a fraction of the $\mathrm{CO}_{2}$ gas diffusion in free air $\left(\mathrm{D}_{\mathrm{o}}\right)$, which for $\mathrm{CO}_{2}$ is $0.139 \mathrm{~cm}^{2} \mathrm{~s}^{-1}$, at $273 \mathrm{~K}$ and $1013 \mathrm{hPa}$ pressure. Within the soil profile the diffusion coefficient is slower than it is in free air because soil particles and soil water increase the tortuousness of the gas pathway. High bulk density (low porosity) will slow gaseous diffusion. Likewise, a saturated wet soil will have much of the pore-space occupied by water which slows gaseous diffusion. Liquid phase $\mathrm{CO}_{2}$ diffusion (in free water) is negligible as it is more than 8,000 times slower than $\mathrm{CO}_{2}$ transport through free air (Moldrup et al., 2000).

There have been a number of equations developed in the past century to predict diffusion coefficients through different soil media (Millington and Quirk, 1961, Millington and Shearer, 1971, Moldrup et al., 2000, Penman, 1940, Sallam et al., 1984). For the soil conditions present at this site, the Penman (1940) equation best described the diffusion coefficient:

$$
\frac{D s}{D o}=0.66 \times a
$$

where $D_{s}$ is the $\mathrm{CO}_{2}$ gas diffusion coefficient in soil $\left(\mathrm{cm}^{2} \mathrm{~s}^{-1}\right), D_{o}$ is the $\mathrm{CO}_{2}$ gas diffusion coefficient in free air $\left(\mathrm{cm}^{2} \mathrm{~s}^{-1}\right)$, and $a$ is the air filled pore-space $\left(\mathrm{m}^{-3} \mathrm{~m}^{-3}\right)$. Soil porosity $\left(\mathrm{m}^{-}\right.$ $\left.{ }^{3} \mathrm{~m}^{-3}\right)$ and volumetric soil water content $\left(\mathrm{m}^{-3} \mathrm{~m}^{-3}\right)$ were linearly interpolated for all sampling depths. The air filled pore-space is simply the volume of air still in the porespace.

The second step to solving the production formula (equation 3 ) is to calculate the change in $\mathrm{CO}_{2}$ concentration with change in depth $(\partial \mathrm{C} / \partial \mathrm{z})$. Here we used an approach described by Gaudinski et al.(2000), whereby $\mathrm{CO}_{2}$ concentration profiles were fit with an exponential function (equation 5): 


$$
\left[\mathrm{CO}_{2}\right]_{z}=\mathrm{CO}_{2 \infty}\left(1-e^{-\beta z}\right)+0.04
$$

where, $\left[\mathrm{CO}_{2}\right]_{z}$ is $\mathrm{CO}_{2}$ concentration (\%) at soil depth z, $\mathrm{CO}_{2 \infty}$ is the asymptotic $\mathrm{CO}_{2}$ concentration reached at an infinite depth, $\beta$ is a fitted parameter, $\mathrm{z}$ is soil depth, and 0.04 is an adjustment factor to achieve near atmospheric $\mathrm{CO}_{2}$ concentrations at the soil surface. When the adjusted $\mathrm{R}^{2}$ from the exponential function was below 0.8 the soil $\mathrm{CO}_{2}$ production calculation was not carried out for that soil pit profile for that particular date as it was felt that the calculated function was inadequate to describe the measured $\mathrm{CO}_{2}$ values. This tended to occur when there was a build up of $\mathrm{CO}_{2}$ just below the soil surface which typically occurred after a rain shower where the upper soil layers became saturated and created a diffusion block. This is indicative of a non-steady state condition. The first derivative of the fit function (equation 5) was calculated to determine the rate of change of $\mathrm{CO}_{2}$ concentration with depth.

Using the calculations from the diffusion coefficient (equation 4) and the change of $\mathrm{CO}_{2}$ concentrations with change in depth (first derivative of equation 5) we could calculate the $\mathrm{CO}_{2}$ production for each vertical layer using equation 3 . We obtained an estimate of soil surface respiration by adding the fluxes from each layer. The quality of the modelling effort was evaluated by comparing the modeled surface flux with the measured surface flux using the IRGA.

\subsection{Isotope analysis}

To verify the origin of the $\mathrm{CO}_{2}$ within the soil profile ${ }^{13} \mathrm{CO}_{2}$ isotope signatures were measured. Soil air samples was taken from each of the control plots at $250 \mathrm{~cm}$ depth, stored in airtight, stainless steel vials and transported to the Centre for Stable Isotope Research and Analysis (KOSI, Georg-August-University of Goettingen, Germany) for analysis using a Isotope Ratio Mass Spectrometer (Finnigan MAT Delta Plus, Bremen, Germany). The isotopic signature can indicate whether the $\mathrm{CO}_{2}$ was produced either biologically or from geological sources. 


\subsection{Data analysis}

We divided the experiment into four time periods. The fist was the "pre-treatment period" which started on February 14, 2007 and lasted until the roof was closed on May 1, 2007 - a total of 77 days. The period of roof closure has been divided into two periods, the first being the initial nine months when the drought effect was still moderate hereafter called "treatment period \#1" (from May 1, 2007 to February 1, 2008; 276 days), followed by "treatment period \#2", which corresponded to the time when the drought effect was more severe and ran until May 15, 2009 when the roof was opened (470 days). The fourth was the "post-treatment period" which extended until September 10, 2009 (116 days).

Throughout the experiment, roof plot measurements were compared to adjacent control plots to compare roof plot ecosystem drought response to normal fluctuations. Individual soil $\mathrm{CO}_{2}$ efflux chamber measurements were averaged for each plot at each measurement date and logarithmically transformed in order to normalize data distributions. The significance of the drought effect difference was tested using linear mixed effects models for the four time periods mentioned above. In the model, the desiccation treatment was considered a fixed effect while the measurement day (from day 1 to day 939) and plot were considered as random effects. Differences were considered significant if $\mathrm{P} \leq 0.05$. Additionally, temporal autocorrelation in this time series $\mathrm{CO}_{2}$ flux dataset was corrected for by using a first order autoregressive model.

The relationship between overall soil $\mathrm{CO}_{2}$ efflux with soil moisture (at $10 \mathrm{~cm}$ depth), soil surface temperature, solar radiation, root biomass and the chamber distance from tree stem were tested using linear regressions. Non linear regressions were used to explain the heterotrophic respiration with soil moisture using an inverse parabolic function. Leaf litter respiration relationship with soil moisture was tested using an exponential function. The reported coefficient of determination $\left(\mathrm{R}^{2}\right)$ in the non-linear model was calculated in the same way as the linear model. An independent t-test was used to identify whether the difference between root biomass measurements between treatments was significant. All statistical analyses were done using the statistical package $\mathrm{R}$ version 2.8.1 (R Development Core Team, 2008). 


\section{Results}

\subsection{Soil moisture}

Soil moisture was recorded continuously in both roof and control plots (Fig. 1b) in a total of 18 soil pits across the project area (three soil pits per plot). Due to the installation delays described earlier, no TDR measurements were made in the control plots during the pre-treatment period, and consequently there is no direct pre-treatment comparison between the control and roof plots. However, soil moisture measurements in the roof plots at $10 \mathrm{~cm}$ depth were within the same range as was measured in the control plots once they were installed. Shortly after roof closure, we started to measure decreases in soil moisture at the soil surface in the drought simulation plots. In these plots the soil moisture decreased during the course of the experiment. During the first nine months (treatment period \#1) the soil surface in the roof plots experienced minor recharges from throughfall that entered between gaps in the roof panels. After the roof coverage was improved in early 2008 surface recharge was minimal. In January 2008, as a result of both improved roof coverage and a natural dry period, soil water contents in the roof plots dropped below permanent wilting point at $10 \mathrm{~cm}$ soil depth and remained below it until the roof was re-opened. At the driest point in the drought experiment in May 2009, just prior to roof opening, the volumetric water content was $0.342 \mathrm{~m}^{3} \mathrm{~m}^{-3}$, which is equivalent to a $\mathrm{pF}$ of 4.46 . According to our measurements permanent wilting point was not reached below a depth of $10 \mathrm{~cm}$. At deeper soil depth (150 and $250 \mathrm{~cm}$ respectively) the difference in soil moisture between the roof and control plots was not as pronounced. Following roof opening, soil moisture in the roof plots began to increase, however, due to the lack of sufficient rainfall in the following months the soil moisture did not return to control plot levels.

In the control plots, soil moisture remained on average wetter than field capacity and did not approach permanent wilting point at any point during the experiment. A strong natural drought was experienced between January and February 2008. The remainder of 2008 was very moist (Fig. 1c.). The onset of an El Niño Southern Oscillation phenomenon in 2009 brought drier conditions to the region, including less frequent rainfall events and as a consequence resulted in drier soil conditions. 


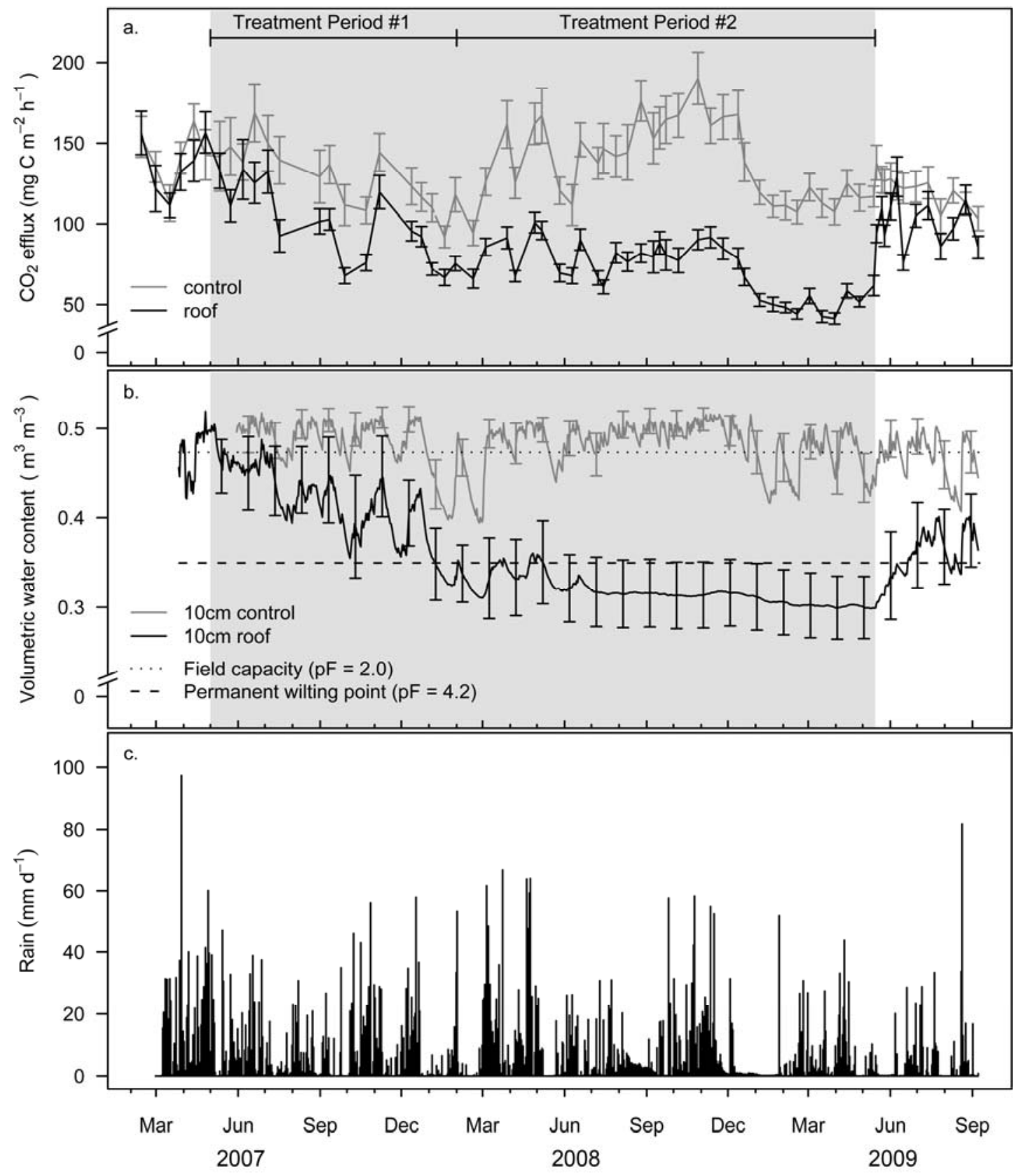

Figure 1: Soil $\mathrm{CO}_{2}$ efflux, volumetric water content and daily precipitation. (a) Average soil surface $\mathrm{CO}_{2}$ efflux in control and roof plots, (b) average volumetric water content (VWC) at $10 \mathrm{~cm}$ soil depth in control and roof plots and (c) daily precipitation. Error bars indicate $\pm 1 \mathrm{SE}$. The shaded area indicates the period of roof closure.

\subsection{Air and soil temperature}

During the two and a half year experiment, we did not measure a seasonal fluctuation in air temperature. Air temperatures just above the soil surface (measured using a handheld thermometer) fluctuated by a total of $7.1^{\circ} \mathrm{C}$ during the 31 month experiment period, ranging from a minimum of $18.5^{\circ} \mathrm{C}$ to a maximum of $25.6^{\circ} \mathrm{C}$ and averaged $22.1 \pm 1.4^{\circ} \mathrm{C}$ $($ mean $\pm \mathrm{SD})$. Air temperature reached a daily maximum in the early afternoon between 
12:00 and 14:00 (Table 3). Correspondingly, the temperature in the soil did not exhibit strong fluctuations, ranging by only $4.5^{\circ} \mathrm{C}$ from a minimum temperature of $19.0^{\circ} \mathrm{C}$ to a maximum of $23.5^{\circ} \mathrm{C}$. The average soil temperature was $20.8 \pm 0.8^{\circ} \mathrm{C}$ (mean $\pm \mathrm{SD}$ ). Daily soil temperature was highest during the late afternoon between 16:00 and 18:00 (Table 3). There was no soil temperature difference between roof and control plots. Soil temperature did not change with soil depth, although the temperature fluctuations became smaller.

\subsection{Soil $\mathrm{CO}_{2}$ efflux and environmental controls}

During the six field measurement campaigns made during the pre-treatment period, soil $\mathrm{CO}_{2}$ efflux emissions were not significantly different between control and roof plots (Table 2, Fig. 1a). Following roof closure, $\mathrm{CO}_{2}$ effluxes in the roof plots began to decline in comparison to the control. The drought effect was not very pronounced during the first nine months, until the end of February 2008. During this first phase of the drought the difference in soil $\mathrm{CO}_{2}$ effluxes between treatments exhibited an initial decline but levelled off at approximately $30 \mathrm{mg} \mathrm{C} \mathrm{m}^{-2} \mathrm{~h}^{-1}(23 \%)$ lower than the control. This first phase of the drought corresponds to treatment period \#1. In early March 2008 the difference in soil $\mathrm{CO}_{2}$ efflux between roof and control plots became more pronounced. During the second drought phase (treatment period \#2) the difference in soil respiration was on average $67 \mathrm{mg} \mathrm{C} \mathrm{m}^{-2} \mathrm{~h}^{-1}$ (48\% lower than the control). Soil $\mathrm{CO}_{2}$ effluxes in the roof plots reached a minimum in late March 2009, where the average respiration rates in the roof plot decreased by $61 \%$ compared to the control $(\mathrm{P}<0.01)$. Over the duration the roof was closed respiration rates decreased an average of $39 \%$ in comparison to the control. Immediately following roof opening $\mathrm{CO}_{2}$ efflux spiked and within a one week period the roof plots were only $14 \%$ lower than the control plots. In the 12 follow up measurements in the post treatment period, roof plot respiration rates increased but rarely surpassed control plot levels. There was only a marginal significant difference $(\mathrm{P}=0.07)$ between the control and roof plots during this time period. Over the duration of the experiment the average annual soil respiration from the control plots was $11.7 \pm 0.3 \mathrm{Mg} \mathrm{C} \mathrm{ha}^{-1}$, while the drought plots respired an annual average of $7.8 \pm 0.3 \mathrm{Mg} \mathrm{Cha}^{-1}$. 


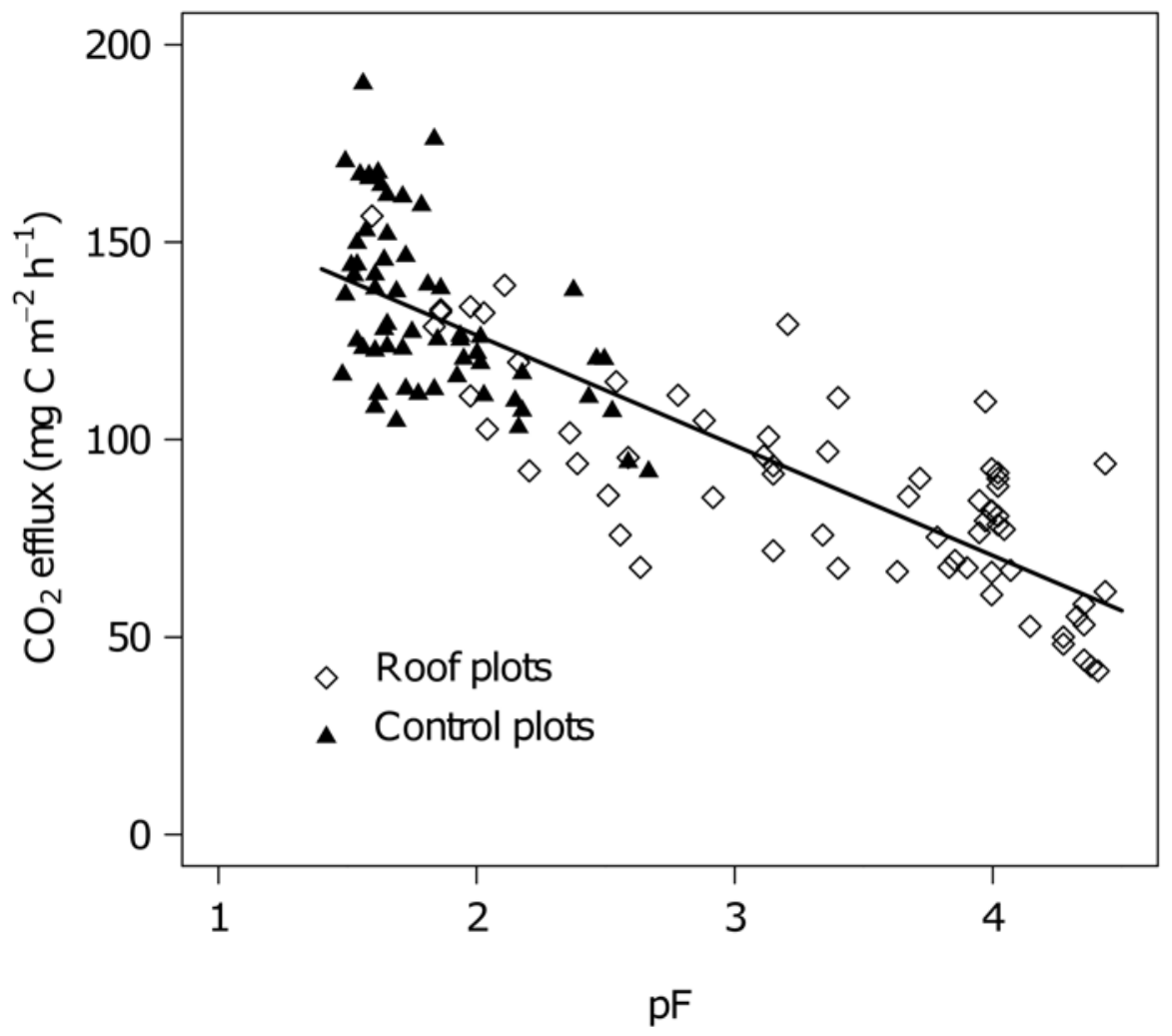

Figure 2: Relationship between soil water potential (pF) and soil $\mathrm{CO}_{2}$ efflux $\left(\mathrm{CO}_{2}\right.$ efflux $\left.=-27.9(\mathrm{pF})+182.3, \mathrm{R}^{2}=0.72, \mathrm{p}<0.05, \mathrm{n}=126\right)$ showing the average soil $\mathrm{CO}_{2}$ efflux measurements from roof and control plots for each measurement campaign. Each point represents the average of $18 \mathrm{CO}_{2}$ efflux measurements. Volumetric Soil moisture was measured using TDR sensors from three soil pits per plot embedded horizontally at $10 \mathrm{~cm}$ soil depth.

Soil $\mathrm{CO}_{2}$ efflux exhibited a strong linear relationship with soil moisture $\left(\mathrm{R}^{2}=0.72\right.$, $\mathrm{P}<0.01)$. Soil respiration rates were highest when soils were very wet and were lowest when soils were very dry (Fig. 2). No detectable relationship was measured between soil respiration and soil temperature or with solar radiation.

Additionally, no correlation was determined between soil moisture and soil temperature, nor was there a strong diurnal pattern exhibited in soil respiration during daytime hours (Table 3). 
Table 2: Experiment soil surface $\mathrm{CO}_{2}$ efflux $\left(\mathrm{mg} \mathrm{C} \mathrm{m}^{-2} \mathrm{~h}^{-1}\right)$, soil air $\mathrm{CO}_{2}$ concentrations (\%) and soil $\mathrm{CO}_{2}$ production for $50 \mathrm{~cm}$ depth intervals $\left(\mathrm{mg} \mathrm{C} \mathrm{m} \mathrm{h}^{-2}\right)$ for different soil depths for the pre-treatment, treatment, post-treatment. Mean value $\pm 1 \mathrm{SE}$. $\mathrm{n}=$ number of sampling campaigns.

\begin{tabular}{|c|c|c|c|c|c|c|c|c|c|c|c|c|}
\hline & \multicolumn{3}{|c|}{ Pre-treatment } & \multicolumn{3}{|c|}{ Treatment period $\# 1 *$} & \multicolumn{3}{|c|}{ Treatment period $\# 2 * *$} & \multicolumn{3}{|c|}{ Post-treatment } \\
\hline & $\mathrm{n}$ & Control & Roof & $\mathrm{n}$ & Control & Roof & $\mathrm{n}$ & Control & Roof & $\mathrm{n}$ & Control & Roof \\
\hline 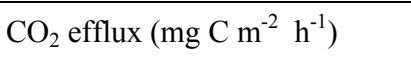 & 6 & $140.4 \pm 12.1$ & $133.4 \pm 12.6$ & 16 & $130.5 \pm 8.5$ & $100.5 \pm 6.5$ & 34 & $138.4 \pm 5.3$ & $71.6 \pm 2.9$ & 12 & $119.3 \pm 6.4$ & $100.6 \pm 5.9$ \\
\hline Soil $\mathrm{CO}_{2}$ concentrations $(\%)$ & 6 & & & 19 & & & 33 & & & 12 & & \\
\hline$-5 \mathrm{~cm}$ & & $0.2 \pm 0.1$ & $0.2 \pm 0.0$ & & $0.4 \pm 0.0$ & $0.3 \pm 0.0$ & & $0.4 \pm 0.0$ & $0.3 \pm 0.0$ & & $0.4 \pm 0.0$ & $0.3 \pm 0.0$ \\
\hline$-10 \mathrm{~cm}$ & & $0.5 \pm 0.0$ & $0.6 \pm 0.1$ & & $0.5 \pm 0.0$ & $0.5 \pm 0.0$ & & $0.5 \pm 0.0$ & $0.4 \pm 0.0$ & & $0.5 \pm 0.0$ & $0.5 \pm 0.0$ \\
\hline$-20 \mathrm{~cm}$ & & $0.8 \pm 0.0$ & $0.7 \pm 0.1$ & & $0.7 \pm 0.0$ & $0.5 \pm 0.0$ & & $0.7 \pm 0.0$ & $0.4 \pm 0.0$ & & $0.7 \pm 0.0$ & $0.5 \pm 0.0$ \\
\hline$-40 \mathrm{~cm}$ & & $1.2 \pm 0.0$ & $1.2 \pm 0.1$ & & $1.1 \pm 0.0$ & $0.8 \pm 0.0$ & & $1.0 \pm 0.0$ & $0.5 \pm 0.0$ & & $1.0 \pm 0.0$ & $0.7 \pm 0.0$ \\
\hline$-75 \mathrm{~cm}$ & & $1.4 \pm 0.1$ & $1.5 \pm 0.1$ & & $1.4 \pm 0.0$ & $1.1 \pm 0.1$ & & $1.3 \pm 0.0$ & $0.8 \pm 0.0$ & & $1.3 \pm 0.0$ & $1.1 \pm 0.0$ \\
\hline$-150 \mathrm{~cm}$ & & $3.2 \pm 0.1$ & $2.8 \pm 0.1$ & & $2.8 \pm 0.1$ & $2.3 \pm 0.1$ & & $2.4 \pm 0.1$ & $1.7 \pm 0.0$ & & $2.5 \pm 0.0$ & $2.2 \pm 0.0$ \\
\hline$-250 \mathrm{~cm}$ & & $3.6 \pm 0.1$ & $3.5 \pm 0.1$ & & $3.4 \pm 0.1$ & $3.3 \pm 0.1$ & & $3.0 \pm 0.1$ & $2.6 \pm 0.1$ & & $3.3 \pm 0.0$ & $3.0 \pm 0.1$ \\
\hline $\mathrm{CO}_{2}$ Production $\left(\mathrm{mg} \mathrm{C} \mathrm{m} \mathrm{m}^{-2} \mathrm{~h}^{-1}\right)$ & & & & 18 & & & 33 & & & 12 & & \\
\hline $0-50 \mathrm{~cm}$ & & - & - & & $69.4 \pm 3.7$ & $60.8 \pm 4.7$ & & $70.9 \pm 3.8$ & $56.0 \pm 1.7$ & & $65.6 \pm 2.5$ & $83.8 \pm 3.8$ \\
\hline $50-100 \mathrm{~cm}$ & & - & - & & $17.8 \pm 0.9$ & $13.0 \pm 1.5$ & & $17.4 \pm 0.9$ & $9.7 \pm 0.4$ & & $15.8 \pm 0.7$ & $13.5 \pm 1.0$ \\
\hline $100-150 \mathrm{~cm}$ & & - & - & & $10.3 \pm 0.3$ & $10.7 \pm 1.1$ & & $9.3 \pm 0.3$ & $5.7 \pm 0.3$ & & $9.2 \pm 0.3$ & $8.4 \pm 0.8$ \\
\hline $150-200 \mathrm{~cm}$ & & - & - & & $5.7 \pm 0.2$ & $6.5 \pm 0.4$ & & $4.6 \pm 0.2$ & $5.0 \pm 0.2$ & & $4.7 \pm 0.3$ & $4.8 \pm 0.2$ \\
\hline $200-250 \mathrm{~cm}$ & & - & - & & $3.6 \pm 0.2$ & $4.6 \pm 0.2$ & & $2.8 \pm 0.1$ & $4.4 \pm 0.1$ & & $3.2 \pm 0.2$ & $3.9 \pm 0.2$ \\
\hline Total $\mathrm{CO}_{2}$ production & & - & - & & $106.8 \pm 4.7$ & $95.6 \pm 7.4$ & & $105.1 \pm 4.9$ & $80.8 \pm 2.5$ & & $98.5 \pm 3.6$ & $114.5 \pm 4.9$ \\
\hline
\end{tabular}

* May 1, 2007 to January 31, 2008

** February 1, 2008 to May 15, 2009 
Table 3: Diurnal soil $\mathrm{CO}_{2}$ efflux, soil temperature and air temperature during daytime hours. The mean values are $\pm \mathrm{SE}$.

\begin{tabular}{|c|c|c|c|c|c|c|c|}
\hline & Time & $\mathrm{n}$ & $\begin{array}{c}\text { Roof Plot } \\
\text { Soil CO } \mathrm{CO}_{2} \text { flux } \\
{\left[\mathrm{mg} \mathrm{C} \mathrm{m}^{-2} \mathrm{~h}^{-1}\right]}\end{array}$ & $\mathrm{n}$ & $\begin{array}{l}\text { Control Plot } \\
\text { Soil CO } \mathrm{CO}_{2} \text { flux } \\
{\left[\mathrm{mg} \mathrm{C} \mathrm{m}^{-2} \mathrm{~h}^{-1}\right]}\end{array}$ & $\begin{array}{l}\text { Soil } \\
\text { temperature } \\
{\left[{ }^{\circ} \mathrm{C}\right]}\end{array}$ & $\begin{array}{l}\quad \text { Air } \\
\text { temperature } \\
{\left[{ }^{\circ} \mathrm{C}\right]}\end{array}$ \\
\hline Mid morning & 08:00-10:00 & 161 & $85.5 \pm 3.1$ & 155 & $117.9 \pm 4.3$ & $20.5 \pm 0.0$ & $20.6 \pm 0.1$ \\
\hline Late morning & $10: 00-12: 00$ & 423 & $87.5 \pm 1.8$ & 492 & $134.4 \pm 2.5$ & $20.7 \pm 0.0$ & $21.9 \pm 0.0$ \\
\hline Early afternoon & $12: 00-14: 00$ & 395 & $88.6 \pm 2.0$ & 389 & $136.8 \pm 2.7$ & $20.9 \pm 0.0$ & $22.6 \pm 0.0$ \\
\hline Mid afternoon & $14: 00-16: 00$ & 216 & $96.7 \pm 3.7$ & 174 & $131.2 \pm 3.5$ & $21.2 \pm 0.0$ & $22.5 \pm 0.1$ \\
\hline Late afternoon & $16: 00-18: 00$ & 14 & $91.0 \pm 13.0$ & 15 & $134.9 \pm 12.1$ & $21.2 \pm 0.1$ & $22.5 \pm 0.1$ \\
\hline
\end{tabular}

\section{4 $\mathrm{CO}_{2}$ production from leaf litter}

Leaf litter respiration contributed an average of $28 \%$ of the total $\mathrm{CO}_{2}$ flux $(35.6$ $\mathrm{mg} \mathrm{C} \mathrm{m} \mathrm{m}^{-2}$ ) (Fig. 3). The contribution percentage was highly correlated to the moisture regime of the leaf litter layer. Leaf litter $\mathrm{CO}_{2}$ respiration was highest when conditions were very wet and decreased exponentially when it became drier, finally approached an asymptote just above zero at a $\mathrm{pF}$ of approximately three (Fig. 5c). The litter layer contributed as much as $63 \%$ to the total respiration when the moisture regime was wet or as little as $4 \%$ when dry. Leaf litter respiration exhibited an exponential relationship with soil moisture sensors embedded in the ground at $10 \mathrm{~cm}$ depth $\left(\mathrm{R}^{2}=0.62, \mathrm{P}<0.001\right)$.

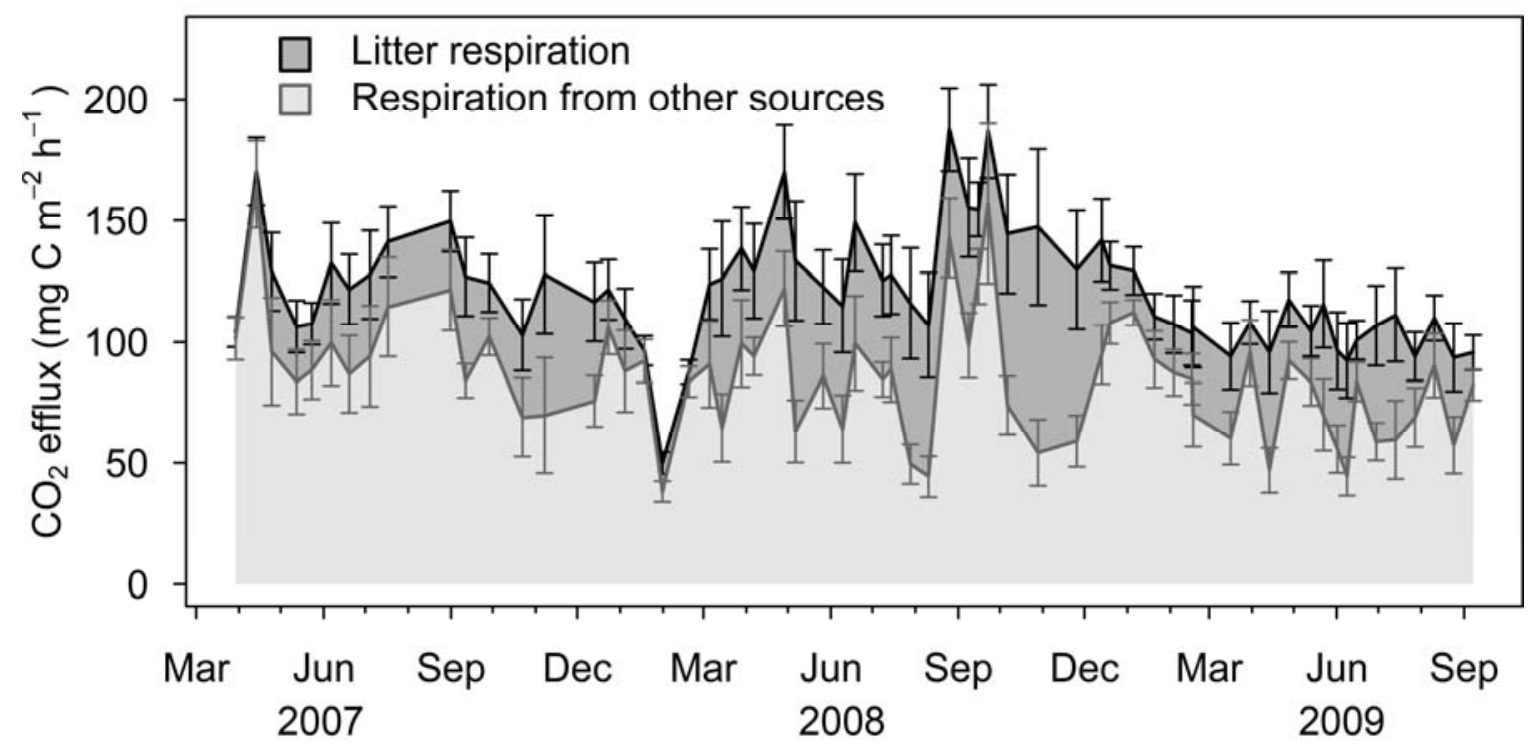

Figure 3: $\mathrm{CO}_{2}$ efflux from leaf litter contribution study in the control plots. The dark grey colour indicates the $\mathrm{CO}_{2}$ production derived from leaf litter, while the light grey colour denotes the $\mathrm{CO}_{2}$ production from within the soil profile from other sources. The error bars indicate the standard error of the six measurements per sampling date. 


\section{5 $\mathrm{CO}_{2}$ production from roots and belowground heterotrophic sources}

In the control plots, roots in the upper $30 \mathrm{~cm}$ contributed an average of $31 \%$ to the total soil $\mathrm{CO}_{2}$ production. In real terms this is an average emission of $39.8 \mathrm{mg} \mathrm{C} \mathrm{m}^{-2} \mathrm{~h}^{-1}$ (Fig. 4a). In the roof plots, the measurements made during the treatment period showed that under dry conditions $\mathrm{CO}_{2}$ efflux from roots still contributed on average $21 \%$ of the total soil respiration although the average emission was only $10.7 \mathrm{mg} \mathrm{C} \mathrm{m}^{-2} \mathrm{~h}^{-1}$ (Fig. 4b). We found that autotrophic (root) respiration exhibited a linear relationship with soil moisture $\left(\mathrm{R}^{2}=0.50, \mathrm{P}<0.001\right)($ Fig. $5 \mathrm{a})$. Autotrophic respiration also showed a significant positive correlation with solar radiation $\left(\mathrm{R}^{2}=0.39, \mathrm{P}<0.01\right)$ and a negative correlation with soil temperature $\left(\mathrm{R}^{2}=0.33, \mathrm{P}<0.01\right)$.

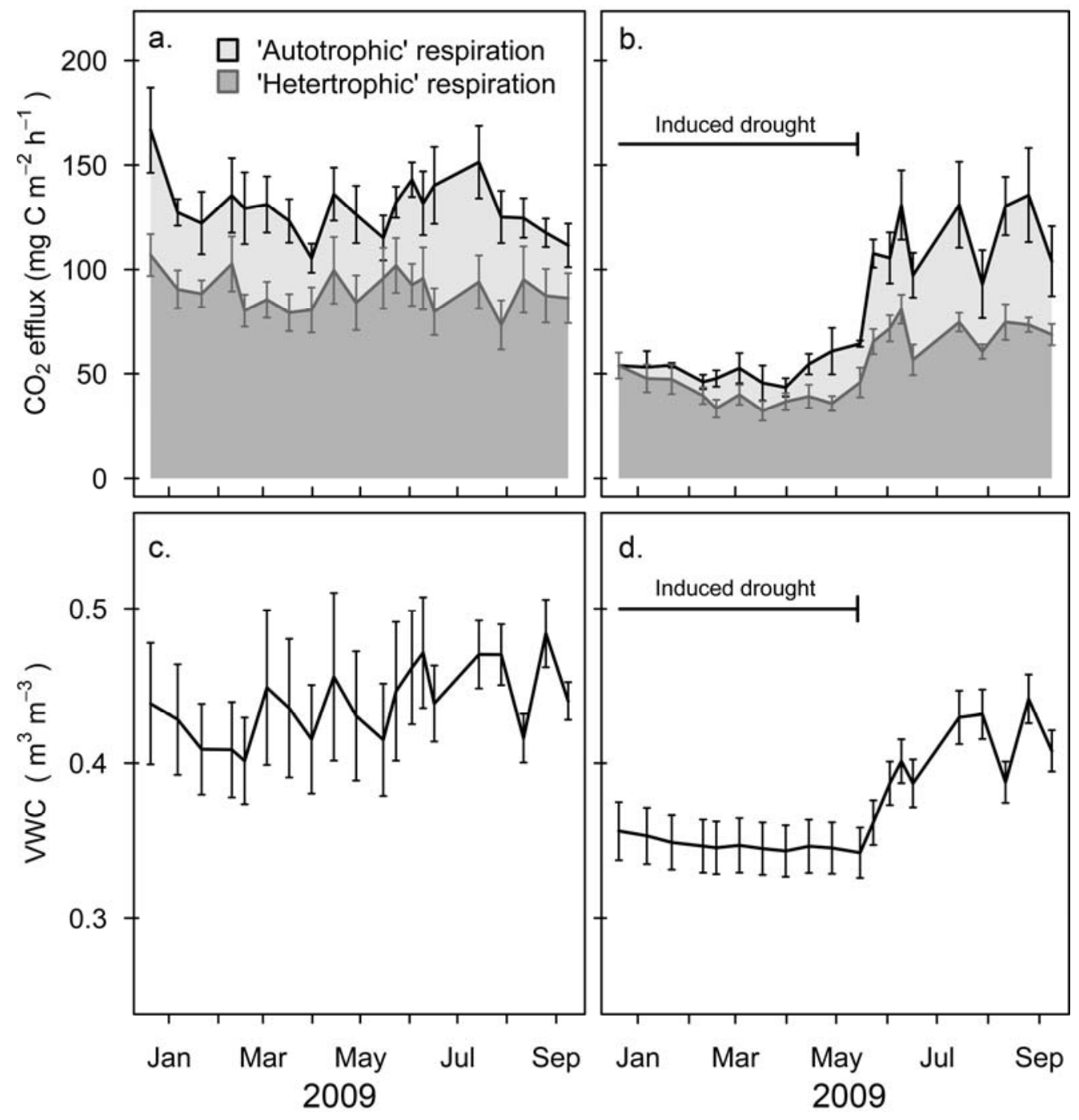

Figure 4: Heterotrophic and autotrophic respiration from (a) control and (b) roof plots as determined from the root exclusion experiment; and the respective volumetric water contents (VWC) in the (c) control and (d) roof plots. Error bars indicate $\pm 1 \mathrm{SE}$. 
Below-ground heterotrophic respiration constituted the largest $\mathrm{CO}_{2}$ production source. In the moist control plots the contribution was on average $41 \%$ of the total $\mathrm{CO}_{2}$ flux, which in real terms is an average emission of $52.9 \mathrm{mg} \mathrm{C} \mathrm{m}^{-2} \mathrm{~h}^{-1}$. However, in drier conditions under the roof, the belowground heterotrophic respiration increased proportionally relative to the total flux (on average $79 \%$ during the most intense period of the drought), although the actual heterotrophic flux decreased (to $40.5 \mathrm{mg} \mathrm{C} \mathrm{m}^{-2} \mathrm{~h}^{-1}$ ). Heterotrophic respiration showed an inverse parabolic relationship with soil moisture; where respiration peaked at approximately field capacity and declined under both wetter and drier conditions $\left(\mathrm{R}^{2}=0.82, \mathrm{P}<0.001\right) \quad$ (Fig. 5b). There was no correlation between belowground heterotrophic respiration and soil temperature.

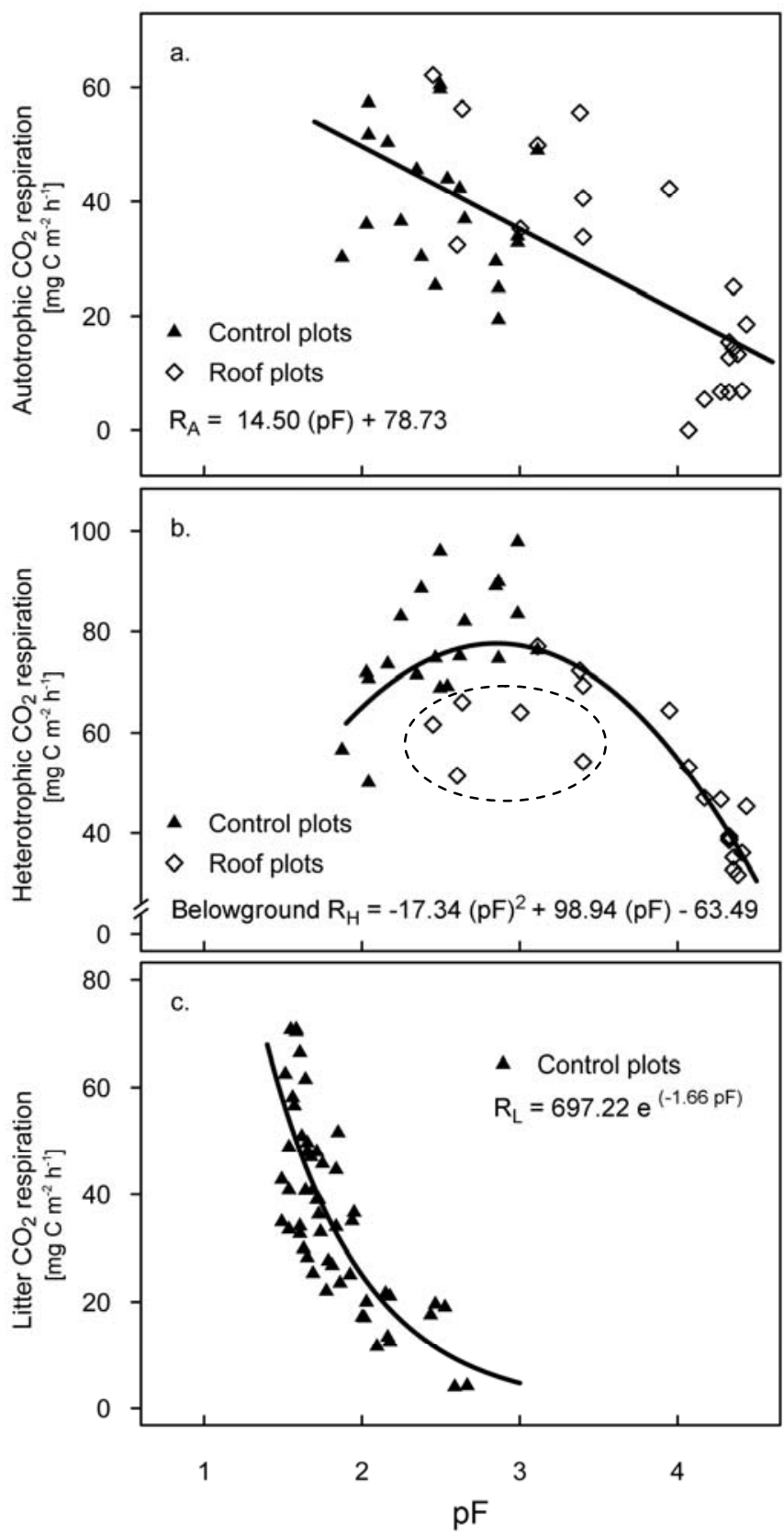

Figure 5: Relationship between soil moisture (at $10 \mathrm{~cm}$ soil depth) and (a) autotrophic $\left(\mathbf{R}_{\mathrm{A}}\right)$, (b) belowground heterotrophic $\left(R_{H}\right)$ and $(c)$ leaf litter respiration $\left(R_{L}\right)$. The points within the dotted ellipse shown in (b) indicate a possible hysteresis effect after rewetting. 


\subsection{Root biomass}

The chamber-base root excavation exercise done four months following the roof opening showed that biomass in the roof plots was on average slightly lower $(1.7 \pm 0.2$ $\mathrm{g} \mathrm{L}^{-1}, \mathrm{n}=18$, (mean $\left.\pm \mathrm{SE}\right)$ ) than the control plot $\left(2.0 \pm 0.1 \mathrm{~g} \mathrm{~L}^{-1} \mathrm{n}=18\right.$, (mean $\left.\pm \mathrm{SE}\right)$ ). The difference was however not significant $(\mathrm{P}=0.11)$. During the root excavation exercise it was visually noted that the roof plots had many more dead roots than the control.

A strong correlation was exhibited between fine root biomass and soil $\mathrm{CO}_{2}$ efflux in both roof $\left(\mathrm{R}^{2}=0.36, \mathrm{P}<0.01\right)$ and control plots $\left(\mathrm{R}^{2}=0.32, \mathrm{P}=0.02\right)$. Slightly weaker relationships were found in the roof plots between soil $\mathrm{CO}_{2}$ efflux and medium $\left(\mathrm{R}^{2}=0.31\right.$, $\mathrm{P}=0.01)$ and coarse roots $\left(\mathrm{R}^{2}=0.20, \mathrm{P}=0.06\right)$, while in the control plots no relationship was evident with the coarser root diameters. The fine root biomass exhibited a negative relationship with the average soil moisture measured at the $\mathrm{CO}_{2}$ chambers sites (in the control plots) during the last four months of the experiment $\left(\mathrm{R}^{2}=0.29, \mathrm{P}<0.05\right)$.

\subsection{Distance to tree stems}

There was no measurable effect between soil $\mathrm{CO}_{2}$ efflux and the distance of the chamber from the surrounding tree stems, or with the dimensions of those trees (diameter or height). We also did not find any relationship between the chambers' root biomass (fine, medium or coarse) and the respective distance to surrounding trees - indicating that root biomass was not necessarily concentrated at the base of the tree stems.

\subsection{Soil $\mathrm{CO}_{2}$ concentrations}

Soil gas $\mathrm{CO}_{2}$ concentrations from different depths in the soil profile from roof and control plots are compared in Figure 6 and in Table 2. For the control plot average we included data from only two of the three control soil pits. We excluded the data from the soil pit in plot four because the pit's location along a drainage pathway resulted in almost constant water saturation which in turn resulted in a high build up of $\mathrm{CO}_{2}$ concentrations just below the soil surface. In general, soil $\mathrm{CO}_{2}$ concentrations showed an exponential increase with soil depth: $\mathrm{CO}_{2}$ concentrations were low near the surface and increased quickly with depth, before finally reaching equilibrium at a depth between 150 and $250 \mathrm{~cm}$. 


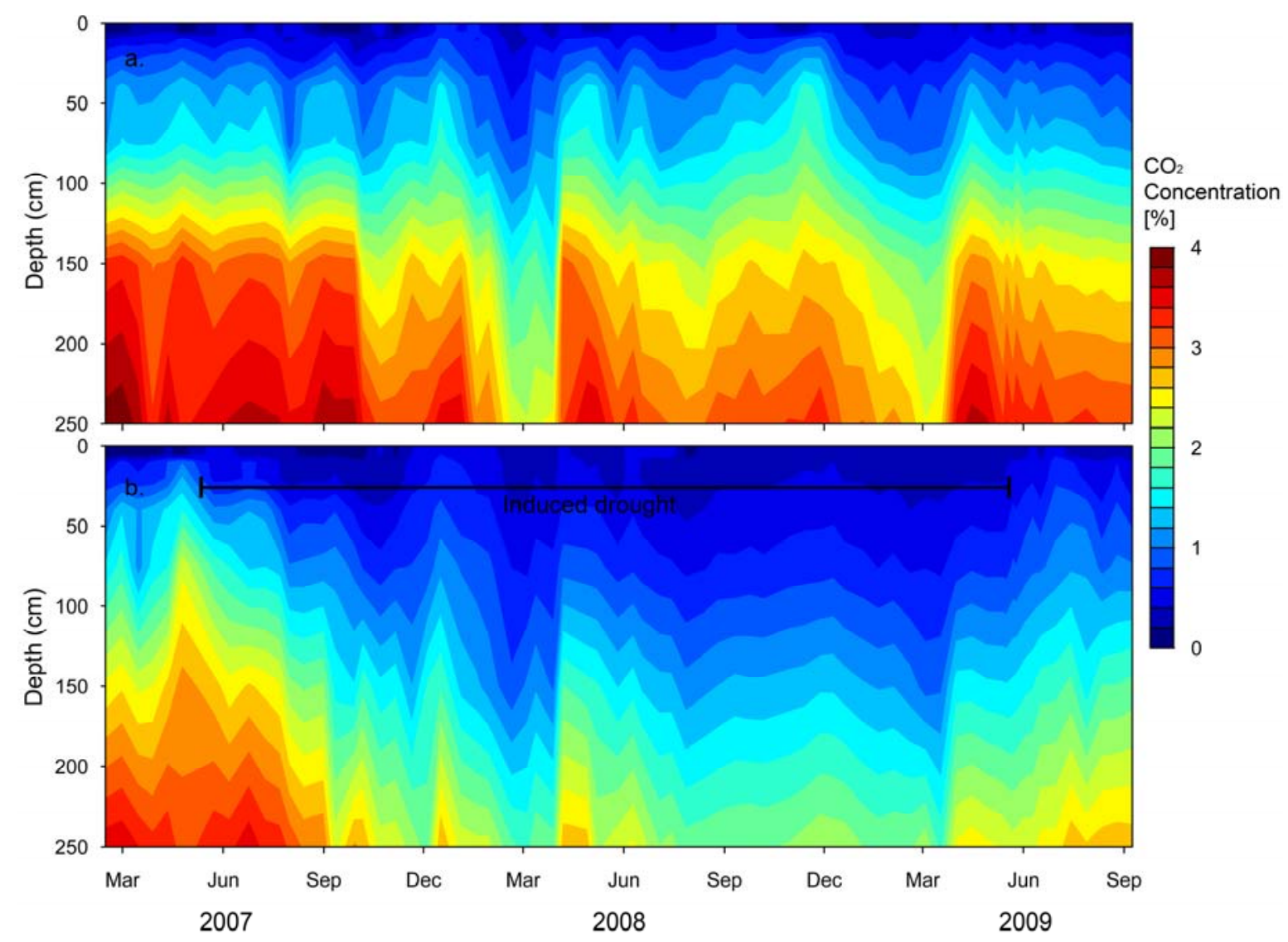

Figure 6: Soil gas $\mathrm{CO}_{2}$ concentrations in the soil profile: Isopleths indicating the average $\mathrm{CO}_{2}$ concentrations (percent) of (a) control plots and (b) roof plots in soil air throughout the period of the experiment.

Pre-treatment $\mathrm{CO}_{2}$ concentrations were comparable at all soil depths, apart from $150 \mathrm{~cm}$ where the control plot average was slightly higher. The onset of the induced drought in the roof plots resulted in the degassing of $\mathrm{CO}_{2}$ leading to a gradual but steady decline in $\mathrm{CO}_{2}$ concentrations in the soil profile at all depth. The strongest proportional decrease to the control plot was found between 20 and $40 \mathrm{~cm}$ depth. Here, the roof $\mathrm{CO}_{2}$ concentrations were on average $45 \%$ lower than in the control for the treatment period. At the lowest point during the latter part of the experiment $\mathrm{CO}_{2}$ concentration was $68 \%$ lower. Upon roof opening post-treatment $\mathrm{CO}_{2}$ concentrations increased in the roof plots but failed to return to control plot levels during the following four months period. During two natural droughts, one in early 2008 and a second in early 2009, we also measured a similar degassing phenomenon in the control plots which was evident at all depths.

The $\delta \mathrm{C}^{13}$ isotope signature of the three $\mathrm{CO}_{2}$ gas samples taken at $250 \mathrm{~cm}$ depth was $-23.5 \pm 0.3 \%$ (mean $\pm \mathrm{SD}$ ) indicating that the $\mathrm{CO}_{2}$ present in the soil profile is biologically produced. 


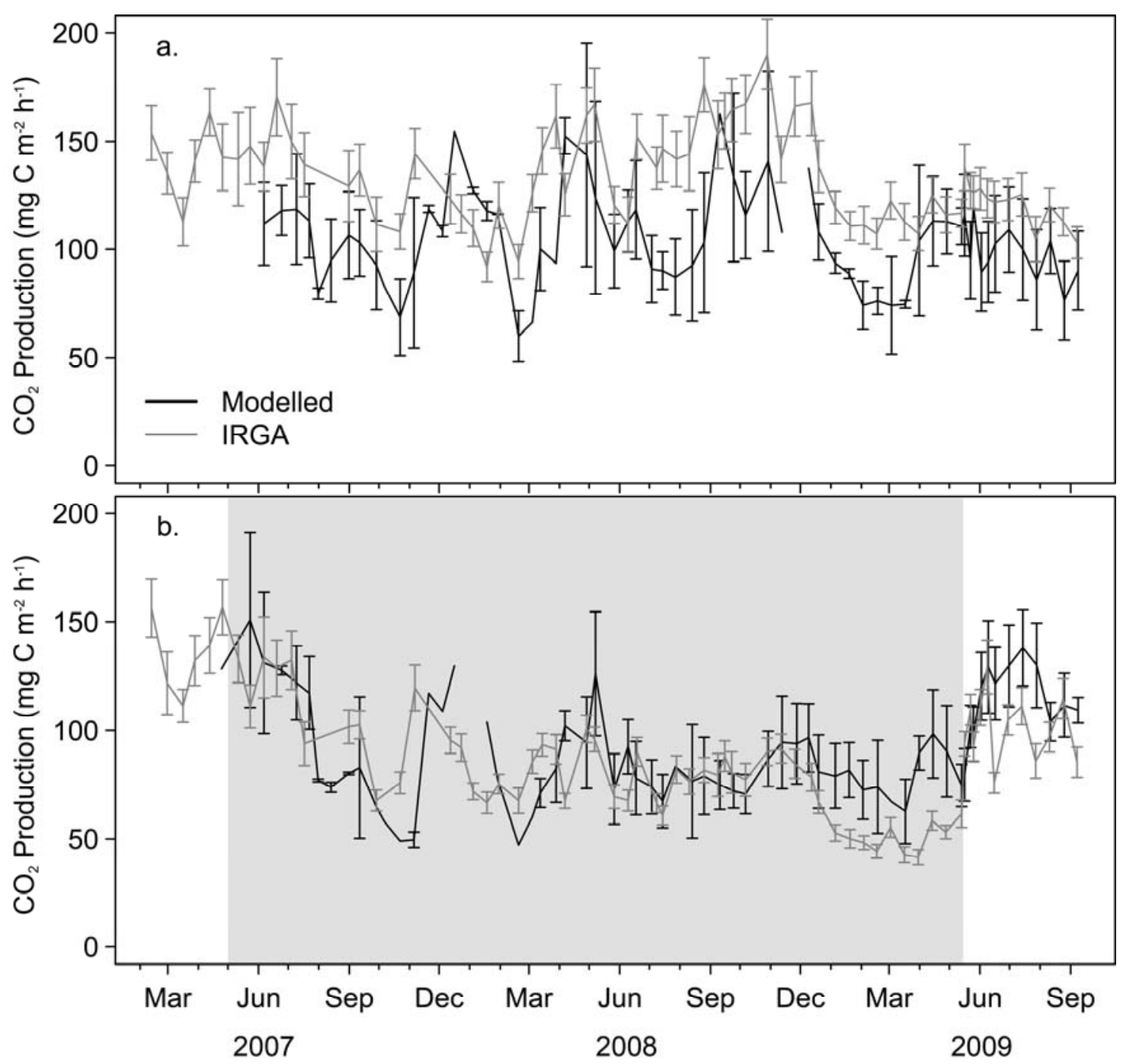

Figure 7: Comparison between modeled $\mathrm{CO}_{2}$ production and surface $\mathrm{CO}_{2}$ efflux measured with the infrared gas analyzer (IRGA) in (a) the control and (b) the roof plots. Error bars indicate \pm 1 SE. Missing average modelled values or error bars were due to non-steady conditions that followed rainfall events affecting the soil $\mathrm{CO}_{2}$ concentration profile, which were subsequently excluded from the production calculation in one or all three soil pits. The shaded area indicates the period of roof closure.

\subsection{Vertical soil $\mathrm{CO}_{2}$ dynamics}

Soil surface $\mathrm{CO}_{2}$ respiration measurements were compared to the modeled $\mathrm{CO}_{2}$ production (from the entire soil profile for each measurement date) to evaluate the accuracy of the modelling process in terms of: (1) the correlation coefficient between these two independent production estimates and (2) to see whether the model could predict the correct magnitude of $\mathrm{CO}_{2}$ production. In the control plots, the $\mathrm{CO}_{2}$ production model estimate of $104.3 \mathrm{mg} \mathrm{C} \mathrm{m}^{-2} \mathrm{~h}^{-1}$ was approximately $22 \%$ lower than the measured IRGA $\mathrm{CO}_{2}$ efflux (Fig. 7a). This underestimation is likely due to the fact that the $\mathrm{CO}_{2}$ production model does not consider leaf litter respiration. In the roof plots the difference between 
modeled and control was minimal where the modeled production estimate was $5 \%$ higher than the measured surface $\mathrm{CO}_{2}$ respiration (Fig. $7 \mathrm{~b}$ ). Unlike in the control plots leaf litter respiration was negligible in the dry roof plots. The modelling approach showed a significant correlation with the surface IRGA measurements (control plot, $\mathrm{R}^{2}=0.23$, $\mathrm{P}<0.001$; roof plot, $\left.\mathrm{R}^{2}=0.37, \mathrm{P}<0.001\right)$.

During the course of the induced drought we modeled soil $\mathrm{CO}_{2}$ production down to 250 cm depth (Fig. 8). $\mathrm{CO}_{2}$ production was concentrated in the top layer of soil. In the control plots, the top $50 \mathrm{~cm}$ produced on average $67 \%$ of the total $\mathrm{CO}_{2}$ (averaged over the duration of the experiment). $\mathrm{CO}_{2}$ production exhibited an exponential decrease with soil depth; it was highest just below the soil surface and approached zero production at around $175 \mathrm{~cm}$ depth.

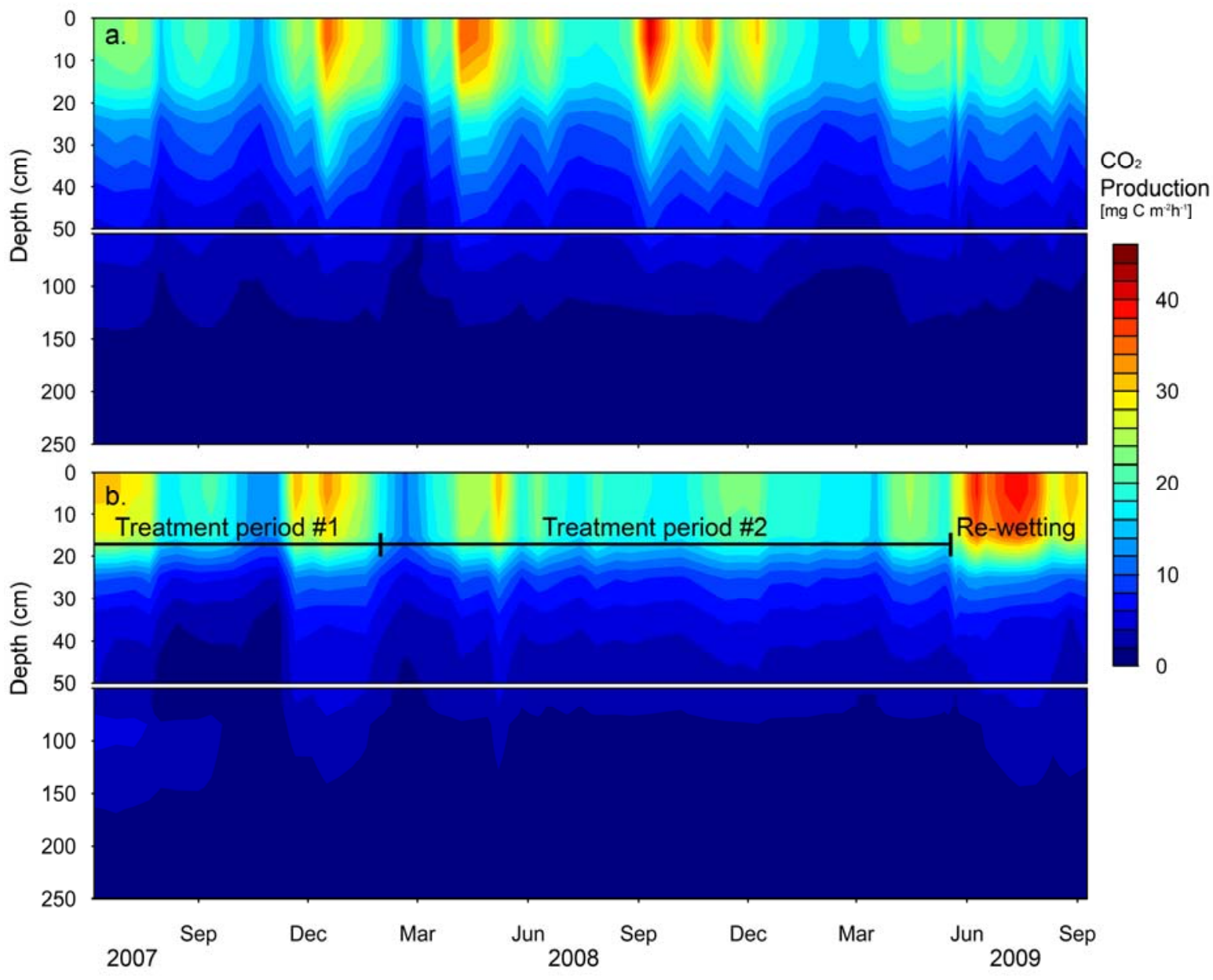

Figure 8: Soil $\mathrm{CO}_{2}$ production in the soil profile: isopleths of average soil $\mathrm{CO}_{2}$ production of (a) control plots and (b) roof plots throughout the experiment period. 


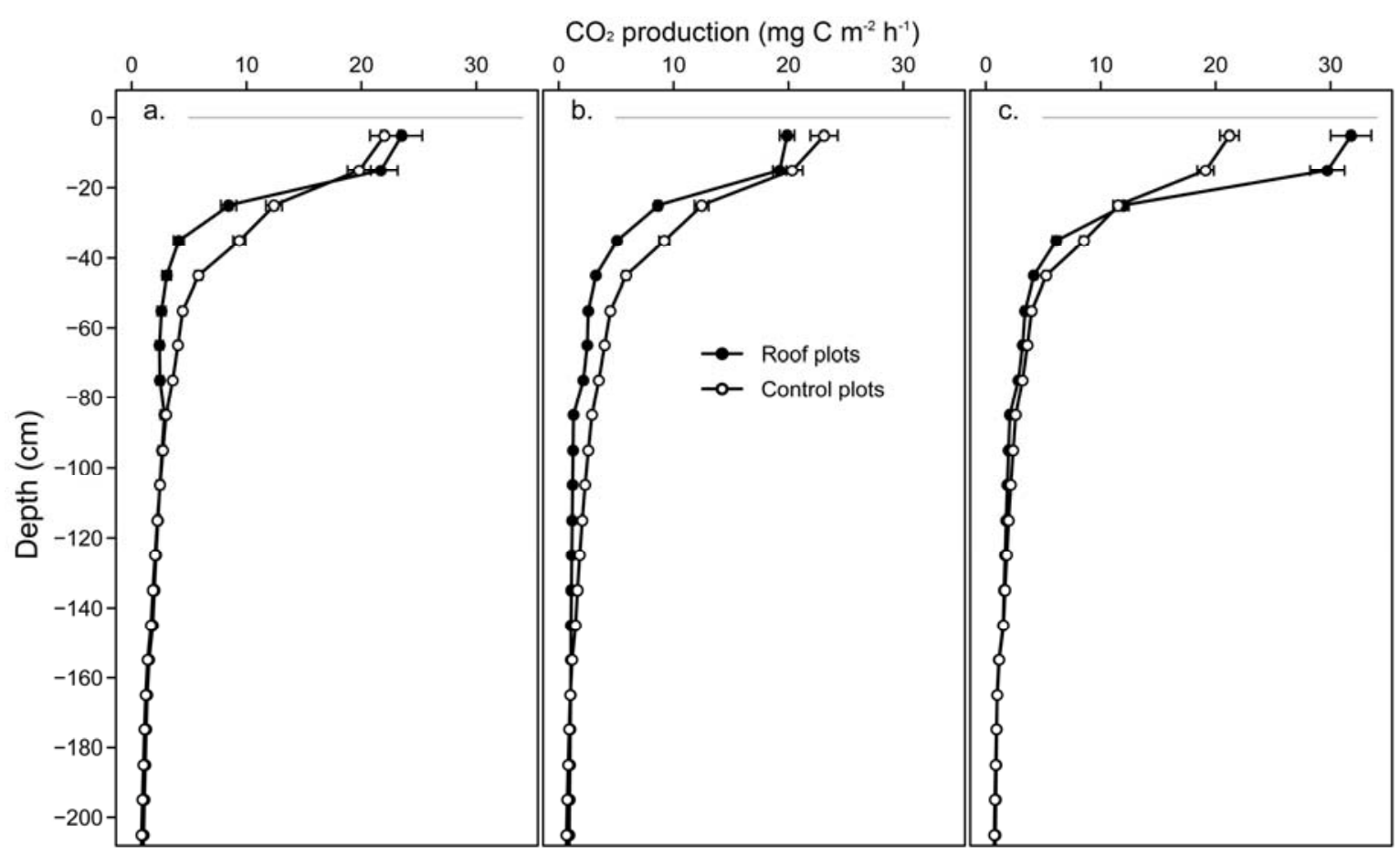

Figure 9: Vertical $\mathrm{CO}_{2}$ production profile comparisons at $10 \mathrm{~cm}$ depth intervals between control and roof plots for (a) treatment period \#1, (b) treatment period \#2, (c) post-treatment period. Error bars indicate $\pm 1 \mathrm{SE}$.

Roof plot $\mathrm{CO}_{2}$ production was compared to the adjacent control plot so as to highlight changes occurring during the course of the induced drought. Comparisons for the different time periods are shown graphically in Fig. 9 and in numerical format in Table 2. Unfortunately, pre-treatment comparisons were not possible because $\mathrm{CO}_{2}$ production was not calculated in the control plots during this time due to the delays in installing the TDR sensors; soil moisture being a required data input to calculate diffusivity. During the first nine months of the induced drought (treatment period \#1) we measured a gradual $\mathrm{CO}_{2}$ production decrease in the roof plots with the exception of a short rebound measured in November - December 2007, which was likely due to a minor rewetting event. Within the soil profile, when we compare the roof to the control plot profile, $\mathrm{CO}_{2}$ production increased slightly in the top $20 \mathrm{~cm}$, then decreased between 20 and $70 \mathrm{~cm}$ and below $70 \mathrm{~cm}$ did not change (Fig. 9a). During the second drought monitoring period (treatment period \#2), the overall $\mathrm{CO}_{2}$ production in the roof plot profiles remained relatively unchanged maintaining an average of $80.8 \mathrm{mg} \mathrm{C} \mathrm{m}^{2} \mathrm{~h}^{-1}$. Unlike the $\mathrm{CO}_{2}$ efflux surface measurements, the modeled $\mathrm{CO}_{2}$ production did not detect the production drop in the first half of 2009 , when the IRGA measured the strongest drought effect (Fig. 7b). In comparison to the control plots, $\mathrm{CO}_{2}$ production in roof plots was lower at all depth during the treatment period \#2 (down to $160 \mathrm{~cm}$ ) (Fig. 9b). During the post treatment period $\mathrm{CO}_{2}$ production 
increased dramatically in the top $20 \mathrm{~cm}$ and surpassed control plot levels. Below $20 \mathrm{~cm}$ $\mathrm{CO}_{2}$ production rose but stabilized at control plot levels (Fig. 9c).

\section{Discussions}

\subsection{Environmental controls regulating soil $\mathrm{CO}_{2}$ production}

Soil $\mathrm{CO}_{2}$ production in the Pono pre-montane tropical rainforest was comparable to soil respiration rates found in tropical rainforests in Asia (Adachi et al., 2009, Ohashi et al., 2008) and in Latin America (Davidson et al., 2008, Davidson et al., 2000, Schwendenmann et al., 2003, Sotta et al., 2006). Like in other studies, soil respiration exhibited high variability both temporally and spatially.

In this ecosystem, soil $\mathrm{CO}_{2}$ efflux was primarily controlled by soil moisture. Soil $\mathrm{CO}_{2}$ efflux was found to exhibit a positive linear relationship with soil matric potential (Fig. 2), where respiration was highest under moist conditions (low $\mathrm{pF}$ ) and low under dry conditions (high $\mathrm{pF}$ ). This linear relationship contrasts with other studies where there was an optimal for soil respiration at intermediate water contents (Davidson et al., 2000, Schwendenmann et al., 2003, Sotta et al., 2006, van Straaten et al., 2010). In our study, soil $\mathrm{CO}_{2}$ efflux did not decrease when conditions became very wet, but instead continued to increase. Upon further investigation, we discovered that respiration from the leaf litter, belowground heterotrophic and from autotrophic sources each exhibited different responses to moisture conditions (Fig. 5). Leaf litter, for example, exhibited an exponential response to moisture regime: respiration was highest when conditions were extremely wet but decreased rapidly under slightly drier conditions and reached a near zero respiration rate at intermediate moisture levels (Fig. 5c). Of the three $\mathrm{CO}_{2}$ production sources, the leaf litter layer was the most sensitive to moisture regime changes given its rapid decrease or increase under even moderate soil moisture changes.

Belowground heterotrophic respiration, as determined in the root contribution study and adjusted to remove the leaf litter component mathematically, was found to exhibit an inverse parabolic relationship with soil moisture (Fig. 5b). Respiration rates were highest at approximately field capacity and decreased under both dry and very wet moisture conditions. The decrease exhibited under wet conditions was likely caused by an oxygen diffusion block in the soil profile which created an anaerobic environment that was not conducive to bacterial and fungal activity (Luo and Zhou, 2006). At the dry end of the moisture gradient, heterotrophic respiration decreased due to soil microorganism drought 
stress. It has been reported that bacterial activity decreases sharply between $\mathrm{pF} 2.7$ and 3.5 and becomes negligible at a the permanent wilting point, below pF 4.2 (Wong and Griffin, 1976). Soil fungi on the other hand, can remain active to a $p F$ of 4.2 because of their ability to extend hyphae across air-filled pore spaces. Under extremely dry conditions soil microorganisms may become dormant, produce spores and/or dehydrate (Schjønning et al., 2003, Stark and Firestone, 1995).

Autotrophic (root) respiration exhibited a linear relationship with soil moisture (Fig 5a): it was low during dry conditions and high when conditions were wet. Finally, when we combine the three different $\mathrm{CO}_{2}$ production source reactions to soil moisture (as described above) we can explain the linear relationship illustrated in Fig. 2.

Overall soil $\mathrm{CO}_{2}$ respiration did not exhibit a significant relationship with either soil temperature or solar radiation. In contrast to other soil respiration studies conducted in the tropics where soil temperature was an important controlling variable for soil respiration (Ohashi et al., 2008, Davidson et al., 2000), overall soil respiration in this ecosystem was unaffected by soil temperature changes. This is however not surprising because the temperature fluctuations at the site were only $4.5^{\circ} \mathrm{C}$ over the length of the 2.5 year experiment. Of the three $\mathrm{CO}_{2}$ production sources, autotrophic respiration showed a mild but significant relationship to soil temperature. Unexpectedly however, the relationship was negative, meaning higher soil temperatures had a negative influence on autotrophic respiration. The temperature effect may be due to physiological processes which vegetation undergoes when soils get warmer. Unfortunately, we could not corroborate this relationship without additional data or analyses.

The expression of photosynthesis on root respiration was apparent when solar radiation increases correspondingly resulted root respiration increases. Similar trends have also been observed by Wofsy et al. (1988), Schwendenmann et al. (2003) and Tang et al. (2005).

\subsection{Spatial, vertical and temporal $\mathrm{CO}_{2}$ production}

Although soil $\mathrm{CO}_{2}$ production exhibited a high variability across the plot, we did not identify a spatial pattern or identify potential controlling variables. Unlike a similar study done in a nearby cacao agroforestry plantation (van Straaten et al., 2010), the distance of the $\mathrm{CO}_{2}$ efflux chamber was from the adjacent tree stems had no influence on the respired soil $\mathrm{CO}_{2}$ efflux, nor were the dimensions (DBH or height) of those adjacent trees relevant. This is not surprising however since even root biomass, which is a good predictor variable 
for autotrophic respiration, did not exhibit a relationship with either distance-to-stem or with tree size.

When we examined the spatial distribution of fine roots across the control plots, we determined that roots actively influenced soil moisture conditions. Areas with the highest root biomass were also found to be the driest. Even though fine root biomass showed a significant positive correlation with soil $\mathrm{CO}_{2}$ efflux, other sources such as leaf litter and belowground microorganisms likely masked the spatial effect that the root mat heterogeneity had on overall $\mathrm{CO}_{2}$ efflux.

Vertically, within the soil profile, $\mathrm{CO}_{2}$ production was highest near the soil surface and decreased exponentially with depth (Fig. 9). $\mathrm{CO}_{2}$ production was highest in the top soil layer because most fine and course roots biomass grew in this layer (Hertel et al., 2009) and most organic substrate was available in the top soil layer for heterotrophic (microorganism) decomposition.

The lack of a clear seasonal pattern in soil $\mathrm{CO}_{2}$ efflux is not particularly surprising since there is also no clear regular annual trend in either precipitation or in temperature at this site. Similarly, the diurnal soil $\mathrm{CO}_{2}$ efflux trends were not very pronounced and showed only a slightly elevated respiration rate in the early afternoon (Table 3 ).

During the 2.5 year experiment, soil $\mathrm{CO}_{2}$ effluxes in the control plot appeared to have been strongly influenced by precipitation frequency and intensity. For example, $\mathrm{CO}_{2}$ respiration rates were highest during the latter half of 2008, during a period of frequent rain showers where soil conditions remained near saturation (Fig. 1). When precipitation frequency and intensity decreased in early 2009 (data not shown), the soil moisture decreased, and as a result soil $\mathrm{CO}_{2}$ efflux also declined.

\subsection{Ecosystem drought response}

In contrast to two drought simulation experiments conducted in tropical forests in Brazil (Davidson et al., 2008, Sotta et al., 2007), we measured a strong decrease in soil $\mathrm{CO}_{2}$ efflux and production caused by the induced drought. However, before exploring the different drought adaptation mechanisms in tropical forest ecosystems, or the lack thereof, we will first examine the drought response exhibited in this forest.

Prior to the roof closure soil $\mathrm{CO}_{2}$ production from control and roof plots were comparable (Fig. 1a and Table 2). We therefore assume that differences following roof closure are due to the induced drought effects. We observed a two-phase drought response in terms of soil $\mathrm{CO}_{2}$ production. The first phase lasted nine months and began when the 
roof was closed. During this first phase $\mathrm{CO}_{2}$ efflux decreased by approximately $30 \mathrm{mg} \mathrm{C}$ $\mathrm{m}^{-2} \mathrm{~h}^{-1}$ in comparison to the adjacent control plots. The decrease occurred within a two months period and then levelled off, maintaining approximately the same difference between the two treatments. The drier conditions found under the roof likely induced a number of near simultaneous drought responses by the different $\mathrm{CO}_{2}$ production sources. First and most importantly, leaf litter respiration decreased under the induced drought conditions. Given the sensitivity to even moderate drying (Fig 5c) it is highly likely that leaf litter layer was the main cause of reduced $\mathrm{CO}_{2}$ production during this first drought phase. Nevertheless, belowground other drought response reactions were also taking place as is evident from results of the vertical $\mathrm{CO}_{2}$ production modelling (Fig. 8b and 9a). While soil $\mathrm{CO}_{2}$ production in the upper $20 \mathrm{~cm}$ layer remained unchanged or even slightly increased, the reductions in $\mathrm{CO}_{2}$ production between the depth of 30 and $70 \mathrm{~cm}$ is thought to be due to microorganism experiencing drought stress and perhaps also due to minor shifts in rooting activity towards the surface. It is speculated that the overall magnitude of autotrophic respiration remained unaffected as tree sap flux densities remained comparable with the control (Schuldt, unpublished data) and the herb and shrub layer still appeared healthy.

In early 2008, the onset of a short but intense natural dry spell combined with the improved roof closure drove the soil matric potential below the permanent wilting point (pF 4.2) at $10 \mathrm{~cm}$ depth. This triggered a series of additional ecosystem drought reactions. During this second and more severe phase of the drought simulation experiment which lasted 15.5 months (treatment period \#2) soil $\mathrm{CO}_{2}$ production declined dramatically: on average $67 \mathrm{mg} \mathrm{C} \mathrm{m}^{-2} \mathrm{~h}^{-1}$ less than emitted from the control. Leaf litter $\mathrm{CO}_{2}$ production likely remained negligible or even increased slightly as leaf litter fall remained unchanged (Schuldt, unpublished data) and would have begun to accumulate increasing the substrate available for decomposition. But unlike the litter layer, more dramatic changes took place belowground. In contrast to the first treatment period, soil $\mathrm{CO}_{2}$ production decreased at all depths in comparison to the control as determined using the soil $\mathrm{CO}_{2}$ production model (Fig 9b). During this simulated drought period both autotrophic and belowground heterotrophic sources showed evidence of drought stress.

Root respiration decreased both because the herb / shrub layer had been severely effected by the drought stress, and also from trees which showed drought stress symptoms in reduced sap flux (Schuldt, unpublished data) and a decrease in stem diameter growth (Moser, unpublished data). In the root excavation exercise that followed the experiment, 
we found that though not significant (perhaps because of root re-colonization within the four month rewetting period), root biomass was lower in the roof plots than in the control plots. We also noted that there were visually more dead roots in the roof plots indicating that the drought was strong enough to invoke substantial root mortality. Contrary to the deep rooted drought response mechanisms found in the Amazonian basin by Nepstad et al. (1994), we found no evidence to suggest that rooting activity shifted to deeper depth levels in order to find water resources. Firstly, a root biomass comparison between the control and roof plots following roof opening did not find drought induced changes at any depth within the soil profile (Moser, unpublished data). Secondly, our own $\mathrm{CO}_{2}$ production model results did not reveal any positive production shift to greater soil depths, which could have been indicative of increased rooting activity. It should be recognized however that this modelling approach, where an exponential function is fit through the $\mathrm{CO}_{2}$ concentrations (Eq. 5), may have the disadvantage that it smoothes out valid $\mathrm{CO}_{2}$ production shifts.

As explained earlier, belowground heterotrophic respiration decreased as the soil dried out. Of the three $\mathrm{CO}_{2}$ production sources, belowground heterotrophic respiration was the most resilient to drought conditions. During the last and most severe part of the drought experiment, decomposition of organic matter by microorganisms was responsible for producing on average $79 \%$ of the total $\mathrm{CO}_{2}$ respired (Fig. 4). We speculate that the high contribution coming from heterotrophic respiration could have two possible explanations. First, it may be caused by a methodological bias inherent of the root trenching methodology where heterotrophic respiration estimates are generally overestimated. The details of the shortcomings are described briefly in the Materials and Method section. Secondly, drought induced root mortality will have increased the substrate availability for microorganism decomposition. And, even though conditions were not optimal the increased labile carbon substrate in the soil provided a larger surface area available for microbial activity.

\subsection{Ecosystem rewetting}

When the roof was opened in May 2009 and throughfall began to rewet the soil, the ecosystem began to recuperate. Both soil surface $\mathrm{CO}_{2}$ efflux and the vertical $\mathrm{CO}_{2}$ production model measured a sharp increase in soil $\mathrm{CO}_{2}$ production immediately following the roof opening, although the $\mathrm{CO}_{2}$ surface efflux measurements using the IRGA rarely surpassed the control during the rewetting phase (Fig. 1a). It is suspected that the initial 
rewetting caused some of the labile carbon stocks that had accumulated during the drought (both above and below ground) to mineralize. Surprisingly however, belowground autotrophic respiration in the roof plots did not return to control plot levels. We suspect this is due to a possible hysteresis effect where soil microbiological communities were still in the process of re-colonizing and recuperating after the drought (the points found circled in Fig 5b). Similar findings have also been reported in other ecosystems that experienced drought and rewetting cycles (Acuña et al., 2005, Strack and Price, 2009).

Root respiration recuperated to control plot levels despite the severe dieback experienced by the herb and shrub layer (Fig 4b), suggesting there was active tree root activity to compensate for decreased root respiration from the understory vegetation. It is speculated that overall soil $\mathrm{CO}_{2}$ efflux did not return to control plot levels during this time because both the understory vegetation and belowground microbial populations were still in the process of recovering. Although the $\mathrm{CO}_{2}$ production model incorrectly overestimated overall $\mathrm{CO}_{2}$ production (as is apparent in Fig. $7 \mathrm{~b}$ ), the model results still highlight that that production increased dramatically at the soil surface (Fig. 8) while below a depth of $20 \mathrm{~cm}$ the $\mathrm{CO}_{2}$ production returned to near control plot levels (Fig. 9c).

\subsection{Modelling of soil $\mathrm{CO}_{2}$ production}

The discrepancy observed in the control plots (Fig. 7a) between the vertical $\mathrm{CO}_{2}$ production model and the IRGA surface measurements is due to the fact that the production model does not consider $\mathrm{CO}_{2}$ produced by the leaf litter layer. As mentioned earlier, leaf litter contributes on average $28 \%$ of the total $\mathrm{CO}_{2}$ production (Fig. 3). In the roof plots this difference was not observed as leaf litter respiration was negligible under the dry conditions. Furthermore, the overestimation of emissions from the $\mathrm{CO}_{2}$ production model during the last year of the experiment (Fig. 7b) is attributed to one soil pit which had higher than average $\mathrm{CO}_{2}$ production.

Both the significant correlation between the modeled $\mathrm{CO}_{2}$ production and the IRGA surface measurements (control, $\mathrm{R}^{2}=0.23$ and roof, $\mathrm{R}^{2}=0.38$ ), as well as the fact that the modeled results were within the same range measured using the IRGA validates the use of the Penman (1940) diffusion coefficient equation in the production model used in this study. Model results obtained by using the diffusion coefficient equations developed for non-aggregated soils by Millington and Shearer (1971), for aggregated soils by Millington and Quirk (1961) and for undisturbed soils by Moldrup et al. (2000) produced results that did not correlate with soil surface emissions and was not of a comparable order of 
magnitude with the $\mathrm{CO}_{2}$ production measured by the IRGA. This validation illustrates that the Penman (1940) equation best described the soil medium's gas diffusion properties.

Although the two independent methods (IRGA and $\mathrm{CO}_{2}$ production model) were significantly correlated the relationship was still not perfect. It is expected that since these two methods of calculating total $\mathrm{CO}_{2}$ production were not made from the same physical location the differences exhibited are likely due to the innate high spatial variability exhibited by soil $\mathrm{CO}_{2}$ production and the lack of enough soil pit replicates.

\subsection{Drought response comparison}

The differences observed in drought response of soil $\mathrm{CO}_{2}$ production between this study and two similar drought simulation experiments conducted in the Amazon The differences observed in drought response of soil $\mathrm{CO}_{2}$ production between this study and two similar drought simulation experiments conducted in the Amazon (Davidson et al., 2008, Davidson et al., 2004, Sotta et al., 2007) highlights a spectrum of drought adaptation mechanisms in tropical forest ecosystems. At one extreme, the throughfall displacement experiment by Davidson et al. $(2008,2004)$ in the Tapajós National Forest, Brazil on an Oxisol, showed little effect to the ecosystem and on soil surface $\mathrm{CO}_{2}$ fluxes. The experiment by Sotta et al. (2007) in the Caxuianã National Forest, Brazil exhibited a moderate three phase $\mathrm{CO}_{2}$ production drought response. And at the other extreme, the experiment described here had a strong drought response.

As Nepstad et al. (2002a), Sotta et al. (2007), and Davidson et al. (2008) each point out, tree rooting depth is an important drought adaptation mechanism. Unlike the two Amazonian roof experiment sites where rooting architecture was in general much deeper ( $>10 \mathrm{~m}$ at Tapajós and up to $5 \mathrm{~m}$ at Caxuianã), trees in the ecosystem at the Pono site were not very deep rooted (max. fine root depth: $2.8 \mathrm{~m}$; max. coarse root depth: $<1 \mathrm{~m}$ (Hertel et al., 2009)). Accordingly, given the lack of established deep roots and the sluggish root redistribution (if any) at the Pono site, the only evident drought response mechanism used here was a passive reaction - waiting for rain.

It is speculated that the lack of a pronounced dry season and the high amount of precipitation in this region of central Sulawesi, Indonesia, meant that forests did not have to adapt mechanisms such as deeper roots to mitigate drought effects. A review paper by Schenk and Jackson (2002) substantiates this generalization, as they found a positive correlation between the length of the dry season and rooting depth in tropical forests and secondly found a negative correlation between annual precipitation and rooting depth 
When we consider soil texture differences and the influence on soil water retention properties, the soil at the Pono site (clay-loam) was somewhere between that of the two other drought experiments $(60-80 \%$ clay at Tapajós and 70-95\% sand at Caxuianã in Brazil). The severity of the drought effect measured at the Pono site in comparison to the two other sites was therefore likely not caused by the soil water holding capacity differences but by other ecosystem drought adaptation.

\section{Conclusions}

The strong decrease in soil $\mathrm{CO}_{2}$ efflux measured during the simulated drought and the subsequent weak rebound measured thereafter during the rewetting phase meant that the overall soil $\mathrm{CO}_{2}$ respired from the roof plots during the 31 month experiment was lower than the adjacent control. The reduced soil $\mathrm{CO}_{2}$ production illustrates how sensitive belowground carbon dynamics in this ecosystem are to drought. The simulated drought not only caused a slow-down in litter and soil organic matter decomposition, but perhaps more concerning for ecosystem health, the drought was severe enough to cause strong root respiration declines. 


\section{Chapter 4}

\section{SYNTHESIS}

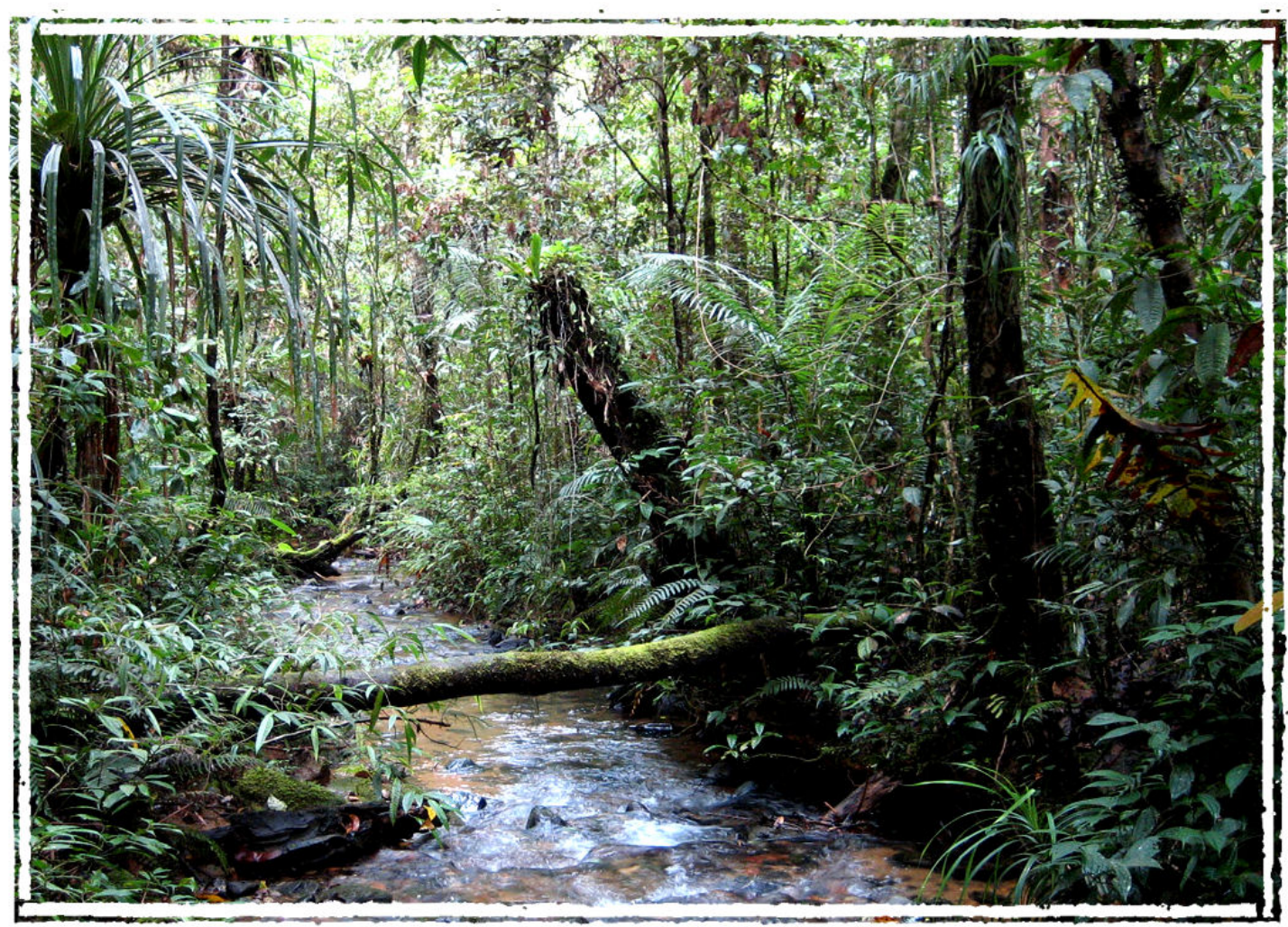




\section{Drought effects on soil $\mathrm{CO}_{2}$ production}

The effects of climate change on hydrological cycles, such as increased frequency and intensities of droughts or changes in precipitation patterns, will have direct consequences on terrestrial carbon stock dynamics (Clark, 2004, Davidson et al., 2008, Heimann and Reichstein, 2008, Nepstad et al., 2002c). Since tropical soils are recognized as a major carbon repository with short residence times (Amundson, 2001, Jobbágy and Jackson, 2000), it is imperative to understand how outside influences such as changes in soil moisture (because of changing precipitation rates and frequencies) will influence carbon fluxes between carbon pools. In this study we evaluated how the flux (emission) of carbon dioxide $\left(\mathrm{CO}_{2}\right)$, a radiatively important gas, is affected by an experimental drought.

The results of the two throughfall reduction experiments that are described in this dissertation have demonstrated that $\mathrm{CO}_{2}$ emissions from soils under different land uses and different soil conditions can exhibit different sensitivities to drought. While both experiments showed decreases in soil $\mathrm{CO}_{2}$ production during the respective induced droughts, the effect in the tropical sub-montane rainforest (at the Pono site) was stronger than the effect measured in the cacao/Gliricidia agroforestry system. A direct comparison of the drought response mechanisms responsible for the different reactions is difficult considering the contrasting nature of the two ecosystems and the different soil characteristics. We can however conclude that in both ecosystems soil moisture was the primary variable responsible for controlling soil $\mathrm{CO}_{2}$ production.

In the cacao / Gliricidia agroforestry roof experiment, soil $\mathrm{CO}_{2}$ efflux measurements were only mildly (13\%) suppressed during the course of the 13-month induced drought. These findings corroborate the research findings of Moser et al. (2010) and Schwendenmann et al. (2010) who studied different physiological reactions in the cacao and Gliricidia trees, and likewise concluded that the ecosystem was tolerant to drought stress. These researchers describe how the shallow rooted cacao understory grown next to the deeper rooted Gliricidia overstory created a favourable set of site conditions that enabled the ecosystem to mitigate serious drought stress.

We attribute the mild drought response on soil $\mathrm{CO}_{2}$ efflux to two additional reasons. First, soil $\mathrm{CO}_{2}$ efflux exhibited an optimal peak at intermediate soil moisture contents but was low when soil conditions became dry (in the induced drought plots), or when the soil became water saturated (in the control plots). This means that respiration differences between control and roof plots may have been masked when soil moisture conditions were saturated in the 
control and concurrently were very dry in roof plots. Secondly, soil $\mathrm{CO}_{2}$ efflux drought response was localized. While at some locations $\mathrm{CO}_{2}$ efflux decreased in close correlation with soil drying, $\mathrm{CO}_{2}$ efflux at other measurement sites did not show any drought effects. Overall, the experiment conducted in the cacao / Gliricidia agroforestry plantation had a $\mathrm{CO}_{2}$ neutral effect: emissions were initially reduced during the induced drought but rebounded and surpassed the control during the five month rewetting phase and thus compensated for earlier declines. If in future drought events the severity is similar or less than the drought imposed in our experiment I do not expected a serious risk of carbon imbalances created from sites with this kind of agroforestry system. However, if droughts are severe enough to cause significant tree mortality, effects on the carbon cycle and particular on atmospheric $\mathrm{CO}_{2}$ feedback potential may be difficult to predict.

In contrast, the sub-montane tropical forest exhibited a strong drought response: soil $\mathrm{CO}_{2}$ production decreased, tree stem diameter increment decreased (Moser, unpublished data), the understory vegetation experienced severe dieback and tree stem sap flow decreased (Schuldt, unpublished data). A two phase drought response was depicted in the soil $\mathrm{CO}_{2}$ emission record over the course of induced drought. During the first nine months, $\mathrm{CO}_{2}$ emissions were only mildly reduced (23\%). This was primarily caused by slowed decomposition of the leaf litter layer. The onset of a natural drought dried the soil to new lows, which subsequently acted as an ecosystem tipping point and triggered drought stress in both root and microbial $\mathrm{CO}_{2}$ production sources. For the next 15 months $\mathrm{CO}_{2}$ production decreased (49\%). After the throughfall reduction roof was opened the ecosystem recovery was slow, and $\mathrm{CO}_{2}$ respiration did not return to normal within the four month rewetting phase. In this ecosystem, soil $\mathrm{CO}_{2}$ emissions had a positive linear relationship with soil moisture. The fact that overall $\mathrm{CO}_{2}$ respiration decreased so strongly under the induced drought conditions highlights the sensitivity of this ecosystem to drought and to the carbon cycle.

Although the comparison of the two experiments showed that there were no positive $\mathrm{CO}_{2}$ emissions released by the soil during the simulated drought (at least during the time period of measurements), it is erroneous to conclude that there were no negative ecosystem interactions with the atmospheric carbon cycle. For instance, drought conditions may also have resulted in physiological carbon allocation changes within trees resulting from decreased photosynthetic carbon uptake. Additionally, vegetation mortality can add significantly to changes in carbon dynamics within the ecosystem. 


\section{Regional drought effect prediction}

At the regional scale, droughts will likely have heterogeneous effects across the landscape, both in natural forests and in cacao agroforests. While some ecosystems will likely exhibit strong signs of drought stress, others will be able to mitigate the impact through either their physiological or morphological traits or because of more favourable micro-site conditions. Biological drought mitigation mechanisms developed by plants to endure drought stresses include: deep and prolific rooting systems which are used to access available water resources; osmotic adjustment to maintain water retention and cell turgor pressure; small and succulent leafs to reduce transpirational water loss; and physiological adaptations to minimize water loss (Farooq et al., 2009). At the biophysical level, site characteristics such as soil type, soil water retention properties and landscape position will also play an important role in determining the extent of the drought impact. Soil $\mathrm{CO}_{2}$ emissions will accordingly vary depending on the ecosystem drought effect.

Discussions on regional drought response on forest carbon emission dynamics can not exclude the mention of the increased risk of fire in the ecosystem. Burning will not only kill trees but will also volatilize sequestered carbon. Research has shown that during drought events, tropical forests margin especially are at increased risk to slash and burn (Page et al., 2002, Van Nieuwstadt and Sheil, 2005). Where under normal conditions it is difficult to burn a wet tropical forest, natural droughts give farmers the opportunity to clear new farm land.

\section{Drought risk prediction in tropical forests}

Worldwide, three large-scale in situ throughfall displacement experiments have been carried out in tropical forests. In addition to the experiments reported here, two experiments of similar length and design were conducted in the Brazilian Amazon forest, in the: "Caxuianã National Forest" as reported by Fisher et al. (2007) and in "Tapajós National Forest" as reported by Nepstad et al. (2002b). In each of the three experiments (including in Pono), droughts effects on soil respiration were measured. The results have been instrumental in illustrating the range of mitigation responses that tropical forest ecosystems can exhibit. The drought response of soil $\mathrm{CO}_{2}$ production ranged from a severe decrease in soil respiration in Pono, to a moderate effect in Caxuianã (Sotta et al., 2007), to a very mild effect in Tapajós (Davidson et al., 2004). Since soil respiration and soil $\mathrm{CO}_{2}$ production is coupled to many ecosystem processes (such as photosynthesis, carbohydrate transfers and microbial activity 
(Tang et al., 2005)), I have used it as a general indicator for ecosystem drought stress. A comparison of the experiment sites and drought responses is given in Table 1. Based on the results of the three experiments, which are spread across different soil types and climate zones on different continents, we can begin to speculate why the ecosystems exhibited such contrasting ecosystem responses and soil respiration drought reactions. Although more research is required, it seems that the drought response hinges largely on the range of drought response mechanisms available within an ecosystem. In these three studies we find a close correlation between rooting depth and the intensity of the drought response (in terms of $\mathrm{CO}_{2}$ production). Likewise, the length of the dry season is correlated positively with rooting depth and negatively with soil $\mathrm{CO}_{2}$ production drought response.

Table 1: Comparison of drought response and biophysical site characteristics of three throughfall displacement experiments in tropical forests. The experiment in Caxuianã was conducted by Sotta et al. (2007), the experiment in Tapajós was conducted by Davidson et al. (2004).

\begin{tabular}{lllllll}
\hline $\begin{array}{l}\text { Simulated } \\
\text { drought } \\
\text { experiment site }\end{array}$ & $\begin{array}{l}\text { Length of } \\
\text { the } \\
\text { experiment } \\
\text { (months) }\end{array}$ & $\begin{array}{l}\text { Drought effect on } \\
\text { soil } \mathrm{CO}_{2} \text { efflux } \\
\text { (compared to } \\
\text { control plot } \\
\text { emissions) }\end{array}$ & $\begin{array}{l}\text { Dry season } \\
\text { length in } \\
\text { months } \\
(<60 \mathrm{~mm})\end{array}$ & $\begin{array}{l}\text { Mean annual } \\
\text { precipitation } \\
(\mathrm{mm})\end{array}$ & $\begin{array}{l}\text { Maximum } \\
\text { rooting depth } \\
\text { of coarse } \\
\text { roots } \\
(\mathrm{m})\end{array}$ & $\begin{array}{l}\text { Soil texture } \\
\text { class }\end{array}$ \\
\hline $\begin{array}{l}\text { Pono, Sulawesi, } \\
\text { Indonesia }\end{array}$ & 31 & $-39 \%$ & 0 & $2,901 *$ & $<0.8$ & Clay loam \\
$\begin{array}{l}\text { Caxuianã, Brazil } \\
\text { Tapajós, Brazil }\end{array}$ & 51 & $-22 \%$ & 1 & 2,272 & $<5$ & Sandy loam \\
& $+18 \%$ & 3 & 2,000 & $>10$ & Clay \\
\hline
\end{tabular}

* Data from 2008

It is generally accepted that ecosystems adapt to their local biophysical environment. Accordingly, tropical forest ecosystems may or may not have developed appropriate drought response mechanisms depending on the historic climatic conditions of the area. At sites like Tapajós in Brazil for example, where there is a pronounced annual dry period, ecosystems have adapted appropriate mechanisms, including deeper rooting architectures to access deep water resources. In contrast, regions where historically there are no pronounced dry seasons, such as in central Sulawesi, ecosystems have not needed to develop appropriate drought mitigation strategies. A review paper by Schenk and Jackson (2002), supported the observation that rooting depth increases with increasing dry season length. Inversely, rooting depth decreased with increased overall precipitation. 
If we assume that the length of the dry season is a good indicator of drought adaptation we might be able to extrapolate ecosystem drought risks simply by using this parameter (length of dry season) alone. Using the WORLDCLIM monthly precipitation dataset (1-km spatial resolution) (Hijmans et al., 2005), I calculated the number of consecutive dry months (less than $60 \mathrm{~mm}$ per month) across the tropics (Fig. 1). The derived map highlights regions that are potentially vulnerable to droughts, should they occur. Areas on the map having a short dry season are less adapted to drought, while areas with long dry seasons have adapted appropriate drought response mechanisms. Accordingly and with caution, given that there are only three such drought experiments conducted, we could extrapolate $\mathrm{CO}_{2}$ production drought responses to the tropics: whereby the Pono case study might represent possible dynamics exhibited by forests at high risk, and the Tapajós drought forests at low risk.

It should be recognized however that there are some limitations to this drought risk map. First, the lack of a dry season does not automatically mean that the ecosystem is vulnerable to drought. For instance, ecosystems may have developed drought adaptations by the periodic exposure to natural drought events which do not occur seasonally. Second, ecosystem adaptations to the climate require very long time periods (centuries or longer) to realize in nature. The WORLDCLIM climate dataset on the other hand, used here has averaged climate patterns from the last few decades and therefore may not accurately reflect actual climate ecosystem adaptations. Third, since the WORLDCLIM dataset is calculated using an interpolation algorithm between climate stations, regions where there are few climate stations (such as in the heart of the Amazon forest) estimates may not be completely accurate. Lastly, the map does not consider site characteristics, such as soil water holding capacities from different textured soils or landscape position. Despite the uncertainties, the map represents initial steps towards extrapolating results achieved from these three cross-continental tropical forest drought experiments into a biome wide context.

The research presented in this thesis provides new insights in the complex nature of tropical ecosystem dynamics in responses to a changing climate. The findings contribute to the topical discussion on drought effects on forest-atmospheric biogeochemical interactions and also on belowground $\mathrm{CO}_{2}$ production dynamics in tropical forest environments of $\mathrm{SE}$ Asia. 


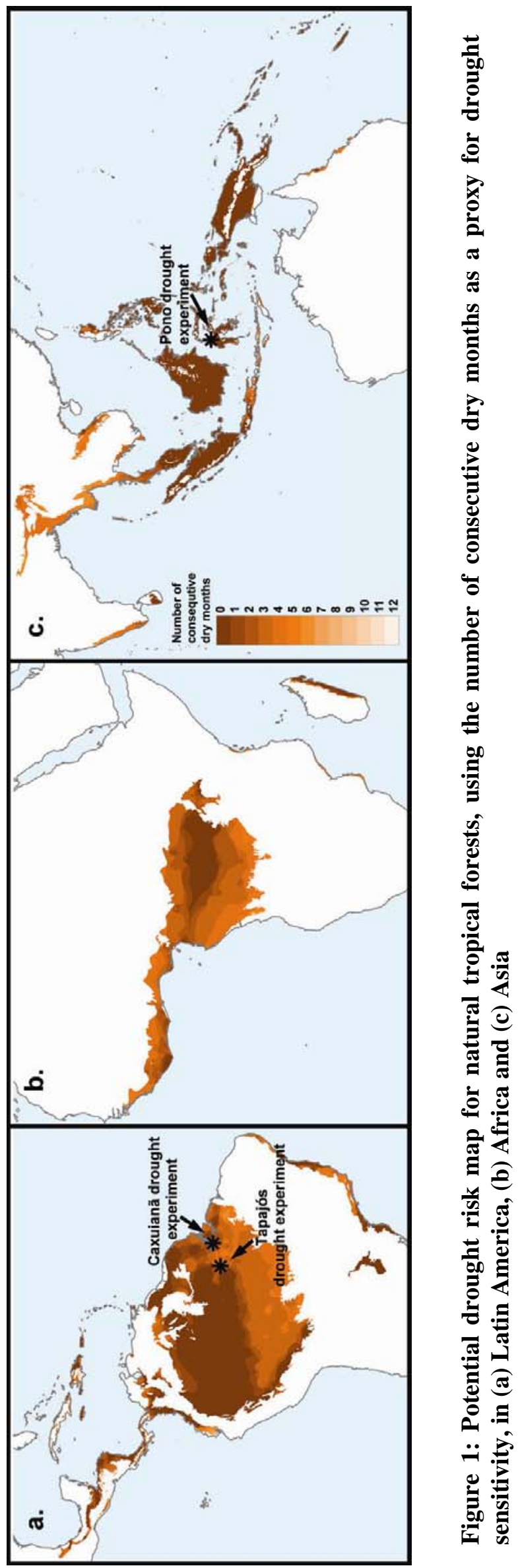




\section{REFERENCES}

Acuña V, Muñoz I, Giorgi A, Omella M, Sabater F, Sabater S (2005) Drought and postdrought recovery cycles in an intermittent Mediterranean stream: structural and functional aspects. Journal of the North American Benthological Society, 24, 919933.

Adachi M, Bekku YS, Rashidah W, Okuda T, Koizumi H (2006) Differences in soil respiration between different tropical ecosystems. Applied Soil Ecology, 34, 258265.

Adachi M, Ishida A, Bunyavejchewin S, Okuda T, Koizumi H (2009) Spatial and temporal variation in soil respiration in a seasonally dry tropical forest, Thailand. Journal of Tropical Ecology, 25, 531-539.

Amundson R (2001) The carbon budget in soils. Annual Review of Earth and Planetary Sciences, 29, 535-562.

Bailey NJ, Motavalli PP, Udawatta RP, Nelson KA (2009) Soil $\mathrm{CO}_{2}$ emissions in agricultural watersheds with agroforestry and grass contour buffer strips. Agroforestry Systems, 77, 143-158.

Bates BC, Kundzewicz ZW, Wu S, Palutikof JP (2008) Climate Change and Water. Technical Paper of the Intergovernmental Panel on Climate Change. Eds. IPCC Secretariat, Geneva, 210 pp.

Brady NC, Weil RR (1999) The Nature and Properties of Soils. Prentice Hall, Upper Saddle River, NJ, 960 pp.

Brando PM, Nepstad DC, Davidson EA, Trumbore SE, Ray D, Camargo P (2008) Drought effects on litterfall, wood production and belowground carbon cycling in an Amazon forest: results of a throughfall reduction experiment. Philosophical Transactions of the Royal Society B-Biological Sciences, 363, 1839-1848.

Clark DA (2004) Sources or sinks? The responses of tropical forests to current and future climate and atmospheric composition. Philosophical Transactions of the Royal Society of London Series B-Biological Sciences, 359, 477-491.

Cox PM, Betts RA, Collins M, Harris PP, Huntingford C, Jones CD (2004) Amazonian forest dieback under climate-carbon cycle projections for the 21 st century. Theoretical and Applied Climatology, 78, 137-156.

Culmsee H, Pitopang R (2009) Tree diversity in sub-montane and lower montane primary rain forests in Central Sulawesi. Blumea, 54, 119-123.

Davidson EA, Nepstad DC, Yoko Ishida F, Brando PM (2008) Effects of an experimental drought and recovery on soil emissions of carbon dioxide, methane, nitrous oxide, and nitric oxide in a moist tropical forest. Global Change Biology, 14, 2582-2590. 
Davidson EA, Verchot LV, Cattânio JH, Ackerman IL, Carvalho JEM (2000) Effects of soil water content on soil respiration in forests and cattle pastures of eastern Amazonia. Biogeochemistry, 48, 53-69.

Davidson EA, Yoko Ishida F, Nepstad DC (2004) Effects of an experimental drought on soil emissions of carbon dioxide, methane, nitrous oxide in a moist tropical forest. Global Change Biology, 10, 718-730.

de Jong E, Schappert HJV (1972) Calculation of soil respiration and activity from $\mathrm{CO}_{2}$ profiles in the soil. Soil Science, 119, 328-333.

Fang C, Moncrieff JB (1999) A model for soil $\mathrm{CO}_{2}$ production and transport 1: Model development. Agricultural and Forest Meteorology, 95, 225-236.

FAO (2009) Food and Agriculture Organization of the United Nations. http://faostat.fao.org

Farooq M, Wahid A, Kobayashi N, Fujita D, Basra SMA (2009) Plant drought stress: effects, mechanisms and management. Agronomy for Sustainable Development, 29, 185-212.

Fisher RA, Williams M, Da Costa AL, Malhi Y, Da Costa RF, Almeida S, Meir P (2007) The response of an Eastern Amazonian rain forest to drought stress: results and modelling analyses from a throughfall exclusion experiment. Global Change Biology, 13, 2361-2378.

Forster P, Ramaswamy V, Artaxo P, Berntsen T, Betts RA, Fahey DW, Haywood J, Lean J, Lowe DC, Myhre G, Nganga J, Prinn R, Raga G, Schulz M, Van Dorland R (2007) Changes in Atmospheric Constituents and in Radiative Forcing. In Climate Change 2007: The Physical Science Basis. Contribution of Working Group I to the Fourth Assessment Report of the Intergovernmental Panel on Climate Change (eds Solomon S, Qin D, Manning M, Chen Z, Marquis M, Averyt KB, Tignor M, Miller HL), pp. 106. Cambridge University Press, Cambridge.

Gaudinski JB, Trumbore SE, Davidson EA, Zheng S (2000) Soil carbon cycling in a temperate forest: radiocarbon-based estimates of residence times, sequestration rates and partitioning of fluxes. Biogeochemistry, 51, 33-69.

Harteveld MA, Hertel D, Leuschner C (2008) Spatial and temporal variability of fine root abundance and growth in tropical moist forests and agroforestry systems (Sulawesi, Indonesia). Ecotropica, 13, 111-120.

Heimann M, Reichstein M (2008) Terrestrial ecosystem carbon dynamics and climate feedbacks. Nature, 451, 289-292.

Hergoualc'h K, Skiba U, Harmand JM, Henault C (2008) Fluxes of greenhouse gases from Andosols under coffee in monoculture or shaded by Inga densiflora in Costa Rica. Biogeochemistry, 89, 329-345.

Hertel D, Moser G, Culmsee H, Erasmi S, Horna V, Schuldt B, Leuschner C (2009) Below- and above-ground biomass and net primary production in a paleotropical 
natural forest (Sulawesi, Indonesia) as compared to neotropical forests. Forest Ecology and Management, 258, 1904-1912.

Hijmans R, J., Cameron S, E., Parra J, L., Jones P, G., Jarvis A (2005) Very high resolution interpolated climate surfaces for global land areas. International Journal of Climatology, 25, 1965-1978.

IPCC (2007) Climate Change 2007: Impacts, Adaptation and Vulnerability. Contribution of Working Group II to the Fourth Assessment Report of the Intergovernmental Panel on Climate Change. Eds. Parry ML, Canziani OF, Palutikof JP, van der Linden PJ, Hanson CE. Cambridge University Press, Cambridge, UK, 976 pp.

Jobbágy EG, Jackson RB (2000) The vertical distribution of soil organic carbon and its relation to climate and vegetation. Ecological Applications, 10, 423-436.

Johnson MS, Lehmann J, Riha SJ, Krusche AV, Richey JE, Ometto J, Couto EG (2008) $\mathrm{CO} 2$ efflux from Amazonian headwater streams represents a significant fate for deep soil respiration. Geophysical Research Letters, 35, 5.

Keil A, Zeller M, Wida A, Sanim B, Birner R (2008) What determines farmers' resilience towards ENSO-related drought? An empirical assessment in central Sulawesi, Indonesia. Climatic Change, 86, 291-307.

Köhler M, Schwendenmann L, Hölscher D (in preparation) Throughfall reduction in a cacao agroforest: tree water use and soil water budgeting.

Kummerow J, Kummerow M, Souza da Silva W (1982) Fine-root growth dynamics in cacao (Theobroma cacao). Plant and soil, 65, 193-201.

Luo Y, Zhou X (2006) Soil Respiration and the Environment. Eds. Academic Press, Burlington, San Diego, London.

McDowell N, Pockman WT, Allen CD, Breshears DD, Cobb N, Kolb T, Plaut J, Sperry J, West A, Williams DG, Yepez EA (2008) Mechanisms of plant survival and mortality during drought: why do some plants survive while others succumb to drought? New Phytologist, 178, 719-739.

Millington RJ, Quirk JP (1961) Permeability of porous solids. Transactions of the Faraday Society, 57, 1200-1207.

Millington RJ, Shearer RC (1971) Diffusion in aggregated porous media. Soil Science, 111, 372-378.

Moldrup P, Olesen T, Schjønning P, Yamaguchi T, Rolston DE (2000) Predicting the gas diffusion coefficient in undisturbed soil from soil water characteristics. Soil Science Society of America Journal, 64, 94-100.

Moser G, Leuschner C, Hertel D, Holscher D, Kohler M, Leitner D, Michalzik B, Prihastanti E, Tjitrosemito S, Schwendenmann L (2010) Response of cocoa trees (Theobroma cacao) to a 13-month desiccation period in Sulawesi, Indonesia. Agroforestry Systems, 79, 171-187. 
Nepstad DC, Decarvalho CR, Davidson EA, Jipp PH, Lefebvre PA, Negreiros GH, Dasilva ED, Stone TA, Trumbore SE, Vieira S (1994) The role of deep roots in the hydrological and carbon cycles of Amazonian forests and pastures. Nature, 372, 666-669.

Nepstad DC, Moutinho P, Dias-Filho MB, Davidson E, Cardinot G, Markewitz D, Figueiredo R, Vianna N, Chambers J, Ray D, Guerreiros JB, Lefebvre P, Sternberg L, Moreira M, Barros L, Ishida FY, Tohlver I, Belk E, Kalif K, Schwalbe K (2002c) The effects of partial throughfall exclusion on canopy processes, aboveground production, and biogeochemistry of an Amazon forest. J. Geophys. Res., 107, doi: 10.1029/2001JD000360

Norman JM, Garcia R, Verma SB (1992) Soil surface $\mathrm{CO}_{2}$ fluxes and the carbon budget of grasslands. Journal of Geophys. Resources, 97, 18845-18853.

Oelbermann M, Voroney RP, Thevathasan NV, Gordon AM, Kass DCL, Schlonvoigt AM (2006) Soil carbon dynamics and residue stabilization in a Costa Rican and southern Canadian alley cropping system. Agroforestry Systems, 68, 27-36.

Ohashi M, Kumagai T, Kume T, Gyokusen K, Saitoh T, Suzuki M (2008) Characteristics of soil $\mathrm{CO}_{2}$ efflux variability in an aseasonal tropical rainforest in Borneo Island. Biogeochemistry, 90, 275-289.

Page SE, Siegert F, Rieley JO, Boehm HDV, Jaya A, Limin S (2002) The amount of carbon released from peat and forest fires in Indonesia during 1997. Nature, 420, 61-65.

Parkinson KJ (1981) An improved method for measuring soil respiration in the field. Journal of Applied Ecology, 18, 221-228.

Penman HL (1940) Gas and vapor movements in soil (I). The diffusion of vapors through porous solids. Journal of Agricultural Science, 30, 436-461.

Phillips OL, Aragao LEOC, Lewis SL, et al. (2009) Drought Sensitivity of the Amazon Rainforest. Science, 323, 1344-1347.

Quinn WH, Zopf DO, Short KS, Yang R (1978) Historical Trends and Statistics of Southern Oscillation, El Nino, and Indonesian Droughts. Fishery Bulletin, 76, 663 678.

R Development Core Team (2008) R: A language and environment for statistical computing. R Foundation for Statistical Computing: Vienna, Austria. ISBN 3900051-07-0, http://www.R-project.org

Raich JW, Schlesinger WH (1992) The Global Carbon-Dioxide Flux in Soil Respiration and Its Relationship to Vegetation and Climate. Tellus Series B-Chemical and Physical Meteorology, 44, 81-99.

Risk D, Kellman L, Beltrami H (2002) Carbon dioxide in soil profiles: Production and temperature dependence. Geophysical Research Letters, 29, 4. 
Sabine CL, Heimann M, Artaxo P, Bakker DCE, Chen CTA, Field CB, Gruber N, Le Quéré C, Prinn R, Richey JE, Lankao PR, Sathaye JA, Valentini R (2004) Current status and past trends of the global carbon cycle. In The Global Carbon Cycle: Integrating Humans, Climate, and the Natural World (eds Field CB, Raupach MR), pp. 17-44. Island Press, Washington D.C.

Sallam A, Jury WA, Letey J (1984) Measurement of gas diffusion under relatively low airfilled porosity. Soil Science Society of America Journal, 48, 3-6.

Schenk HJ, Jackson RB (2002) The global biogeography of roots. Ecological Monographs, 72, 311-328.

Schjønning P, Thomsen IK, Moldrup P, Christensen BT (2003) Linking soil microbial activity to water- and air-phase contents and diffusivities. Soil Science Society of America Journal, 67, 156-165.

Schlesinger WH, Winkler PJ, Megonigial JP (2000) Soils and the global carbon cycle. In The carbon cycle (eds Wigley TML, Schimel DS), pp. 93-101. Cambridge University Press, Cambridge, UK.

Schwendenmann L, Veldkamp E (2006) Long-term $\mathrm{CO}_{2}$ production from deeply weathered soils of a tropical rain forest: evidence for a potential feedback to climate warming. Global Change Biology, 12, 1-16.

Schwendenmann L, Veldkamp E, Brenes T, O’Brien JJ, Mackensen J (2003) Spatial and temporal variation in soil $\mathrm{CO}_{2}$ efflux in an old-growth neotropical rain forest, $\mathrm{La}$ Selva, Costa Rica. Biogeochemistry, 64, 111-128.

Schwendenmann L, Veldkamp E, Moser G, Hölscher D, Köhler M, Clough Y, Anas I, Djajakirana G, Erasmi S, Hertel D, Leitner D, Leuschner C, Michalzik B, Propastin P, Tjoa A, Tscharntke T, van Straaten O (2010) Effects of an experimental drought on the functioning of a cacao agroforestry system, Sulawesi, Indonesia. Global Change Biology, 16, 1515-1530.

Sheffield J, Wood EF (2008) Projected changes in drought occurrence under future global warming from multi-model, multi-scenario, IPCC AR4 simulations. Climate Dynamics, 31, 79-105.

Šimůnek J, Šejna M, Saito H, Sakai M, van Genuchten MT (2008) The Hydrus-1D Software Package for Simulating the One-Dimensional Movement of Water, Heat, and Multiple Solutes in Variably-Saturated Media. Riverside, California, USA.

Sivakumar MVK, Das HP, Brunini O (2005) Impacts of present and future climate variability and change on agriculture and forestry in the arid and semi-arid tropics. Climatic Change, 70, 31-72.

Sotta ED, Veldkamp E, Guimaraes BR, Paixao RK, Ruivo MLP, Almeida SS (2006) Landscape and climatic controls on spatial and temporal variation in soil $\mathrm{CO}_{2}$ efflux in an Eastern Amazonian Rainforest, Caxiuana, Brazil. Forest Ecology and Management, 237, 57-64. 
Sotta ED, Veldkamp E, Schwendenmann L, Rocha Guimarães B, Keila Paixão R, de Lourdes P. Ruivo M, Carlos Lola da Costa A, Meir P (2007) Effects of an induced drought on the soil $\mathrm{CO}_{2}$ production and soil $\mathrm{CO}_{2}$ efflux in an Eastern Amazonian Rainforest, Brazil. Global Change Biology, 13, 2218-2229.

Stark JM, Firestone MK (1995) Mechanisms for Soil-Moisture Effects on Activity of Nitrifying Bacteria. Applied and Environmental Microbiology, 61, 218-221.

Strack M, Price JS (2009) Moisture controls on carbon dioxide dynamics of peatSphagnum monoliths. Ecohydrology, 2, 34-41.

Tang JW, Baldocchi DD, Xu L (2005) Tree photosynthesis modulates soil respiration on a diurnal time scale. Global Change Biology, 11, 1298-1304.

Tian H, Melillo JM, Kicklighter DW, McGuire AD, Helfrich J, Moore B, Vorosmarty CJ (2000) Climatic and biotic controls on annual carbon storage in Amazonian ecosystems. Global Ecology and Biogeography, 9, 315-335.

Timmermann A, Oberhuber J, Bacher A, Esch M, Latif M, Roeckner E (1999) Increased El Nino frequency in a climate model forced by future greenhouse warming. Nature, 398, 694-697.

Trumbore S (2006) Carbon respired by terrestrial ecosystems - recent progress and challenges. Global Change Biology, 12, 141-153.

Trumbore SE, Davidson EA, Decamargo PB, Nepstad DC, Martinelli LA (1995) Belowground cycling of carbon in forests and pastures of eastern Amazonia. Global Biogeochemical Cycles, 9, 515-528.

van Genuchten MT (1980) A Closed-Form Equation for Predicting the Hydraulic Conductivity of Unsaturated Soils. Soil Science Society of America Journal, 44, 892-898.

Van Nieuwstadt MGL, Sheil D (2005) Drought, fire and tree survival in a Borneo rain forest, East Kalimantan, Indonesia. Journal of Ecology, 93, 191-201.

van Straaten O, Veldkamp E, Köhler M, Anas I (2010) Spatial and temporal effects of drought on soil $\mathrm{CO}_{2}$ efflux in a cacao agroforestry system in Sulawesi, Indonesia. Biogeosciences, 7, 1223-1235.

Veldkamp E, O'Brien JJ (2000) Calibration of a Frequency Domain Reflectometry Sensor for Humid Tropical Soils of Volcanic Origin. Soil Science Society of America Journal, 64, 1549- 1553.

Wang CK, Yang JY (2007) Rhizospheric and heterotrophic components of soil respiration in six Chinese temperate forests. Global Change Biology, 13, 123-131.

Williamson GB, Laurance WF, Oliveira AA, Delamonica P, Gascon C, Lovejoy TE, Pohl L (2000) Amazonian tree mortality during the 1997 El Nino drought. Conservation Biology, 14, 1538-1542. 
Wofsy SC, Harriss RC, Kaplan WA (1988) Carbon-Dioxide in the Atmosphere over the Amazon Basin. Journal of Geophysical Research-Atmospheres, 93, 1377-1387.

Wong PTW, Griffin DM (1976) Bacterial movements at high matric potentials. 1. Artificial and natural soils. Soil Biology \& Biochemistry, 8, 215-218. 
Taking a moment to reflect on the events of the last three and a half years makes me realize what a fulfilling $\mathrm{PhD}$ experience this has been. It has given me the opportunity to develop both professionally and personally. This experience would not have been such a big success without the input from a number of important people:

First and foremost, I want to thank Prof. Edzo Veldkamp for supervising me through this $\mathrm{PhD}$ thesis. I appreciated the critical feedback, the encouraging attitude and the engaged discussions we had over the course of the last three years. I am very grateful to him for giving me the opportunity to go to Indonesia for my research.

The successful fieldwork implementation is credited to my field assistant Purwanto, who was extremely dedicated, hardworking, independent and trustworthy. Special thanks are also extended to my local assistants in Toro: Jamaludin and Gerson, who worked tirelessly in the field often under difficult conditions.

Logistical support provided by numerous people in different capacities helped make this project a resounding success. This includes:

- $\quad$ The STORMA coordination office: Wolfram Lorenz, Melanie Grosse,

Muhammad Sigit Andhi Rahman, and the talented team of drivers: Pak Alex, Pak

Dullah, Pak Rizal, Pak Baso and Pak Gauk.

- $\quad$ The STORMA laboratory: Stefan Köhler and his team of lab technicians.

- $\quad$ and in Göttingen PTS: Gisela Kutscher

I am grateful to Dr. Luitgard Schwendenmann for her assistance in many capacities during the project: from giving suggestions, to being open for discussions, and finally for critically reviewing my Synthesis.

Thanks are also extended to Birgit Köhler for her help with the gas diffusion modelling.

I also want to thank my colleagues in the STORMA project, particularly Michael Köhler and Bernhard Schuldt, who helped make the Sulawesi experience unforgettable.

For my friends and colleagues in Goettingen, especially Guntars Martinson and Wolde Mekuria, I want to thank you for your constant support and the engaging discussions.

I gratefully acknowledge the financial support provided for "B6" subproject within the SFB 552 "Stability of Rainforest Margins" (STORMA) project by the German Science Foundation (DFG).

On a personal note, I'd like to thank to my parents, my brother and Babsi for their unwavering support. I am especially grateful to my Papa, who was always available to give me a helping hand either with English edits or simply to discuss ideas.

Last but not least, thanks to my girlfriend Julia for her incredible patience and encouragement! 


\section{DEClaRATION OF ORIGINALITY AND CERTIFICATE OF OWNERSHIP}

I, Oliver van Straaten, hereby declare that I am the sole author of this dissertation entitled "Drought effects on soil carbon dioxide efflux in two ecosystems in Central Sulawesi, Indonesia". All references and data sources that were used in the dissertation have been appropriately acknowledged. I furthermore declare that this work has not been submitted elsewhere in any form as part of another dissertation procedure.

Goettingen, February 19, 2010

(Oliver van Straaten) 


\section{About THE Author}

\section{Curriculum Vitae: Oliver van Straaten}

Personal Details

Date of Birth:

16.02.1977

Place of Birth:

Bukoba, Tanzania

Nationality:

Canadian

\section{Education}

$09.2006-03.2010$

Georg-August University of Goettingen, Goettingen, Germany

Ph.D. in Faculty of Forest Sciences and Forest Ecology

$09.2001-03.2003$

ITC, International Institute for Geo-Information Science and Earth

Observation, Enschede, the Netherlands

Masters of Science in Natural Resource Management, Forestry for

Sustainable Development (with Distinction)

$09.1996-05.2000$

Lakehead University, Thunder Bay, Ontario, Canada

Bachelor of Science in Forestry (with Honours)

Work Experience

$10.2003-03.2006$

World Agroforestry Centre (ICRAF) / International Water

Management Institute (IWMI): Nairobi, Kenya \& Colombo, Sri Lanka

$01.2005-07.2005$

Tsunami Disaster Recovery Operation: Sri Lanka

$05.2000-04.2001$

Ontario Ministry of Natural Resources: Nipigon, Ontario, Canada

2003 (4 months)

KBM Forestry Consultants: Thunder Bay, Ontario, Canada

2001,1999,1997

Domtar Forest Resources: Red Rock and White River, Ontario,

(each year 4 months)

Canada

1998 (4 months)

Blue Ridge Lumber: Whitecourt, Alberta, Canada 


\section{Publications list: Oliver van Straaten}

\section{Peer reviewed publications:}

van Straaten O, Veldkamp E, Köhler M, Anas I (2010) Spatial and temporal effects of drought on soil CO2 efflux in a cacao agroforestry system in Sulawesi, Indonesia. Biogeosciences, 7, 1223-1235.

Schwendenmann L, Veldkamp E, Moser G, Hölscher D, Köhler M, Clough Y, Anas I, Djajakirana G, Erasmi S, Hertel D, Leitner D, Leuschner C, Michalzik B, Propastin P, Tjoa A, Tscharntke T, van Straaten O (2010) Effects of an experimental drought on the functioning of a cacao agroforestry system, Sulawesi, Indonesia. Global Change Biology, $16,1515-1530$.

Trabucco A, Zomer R, Bossio D, van Straaten O, Verchot L (2008) Climate change mitigation through afforestation/reforestation: A global analysis of hydrologic impacts with four case studies Agriculture, Ecosystems \& Environment, 126, 81-97.

Verchot L, Zomer R, van Straaten O, Muys B (2007) Implications of country-level decisions on the specification of crown cover in the definition of forests for land area eligible for afforestation and reforestation activities in the CDM. Climatic Change, 81, 415-430.

\section{Book Chapters:}

Trabucco A, Bossio D, van Straaten O (2008) Carbon Sequestration, Land Degradation and Water. In Conserving Land, Protecting Water (eds Bossio D, Geheb K). CAB International, Oxfordshire.

Nangendo G, van Straaten O, De Gier A (2005) Biodiversity Conservation through Burning: A Case Study of Woodlands in Budongo Forest Reserve, NW Uganda. In African Forests Between Nature And Livelihood Resource: Interdisciplinary Studies in Conservation and Forest Management (eds Ros-Tonen M, Dietz T). Mellen Press, Lewiston.

\section{Reports:}

Zomer R, Trabucco A, van Straaten O, Bossio D (2006) Carbon, Land and Water: A Global Analysis of the Hydrologic Dimensions of Climate Change Mitigation through Afforestation / Reforestation. pp. 48. International Water Management Institute, Colombo, Sri Lanka. 